POLLYANA BULGARELLI STEVANATTO

ANÁLISE DO PAPEL DAS CICLOOXIGENASES 1 E 2 NA MIGRAÇÃO DA LINHAGEM CELULAR DE GLIOMA HUMANO U251-MG

Dissertação apresentada ao Programa de Pós-Graduação em Biologia Celular e Tecidual do Instituto de Ciências Biomédicas da Universidade de São Paulo, para obtenção do Título de Mestre em Ciências. 
POLLYANA BULGARELLI STEVANATTO

\section{ANÁLISE DO PAPEL DAS CICLOOXIGENASES 1 E 2 NA MIGRAÇÃO DA LINHAGEM CELULAR DE GLIOMA HUMANO U251-MG}

Dissertação apresentada ao Programa de Pós-Graduação em Biologia Celular e Tecidual do Instituto de Ciências Biomédicas da Universidade de São Paulo, para obtenção do Título de Mestre em Ciências.

Área de concentração: Biologia Celular e Tecidual.

Orientador: Profa. Dra. Alison Colquhoun.

Versão original 
DADOS DE CATALOGAÇÃO NA PUBLICAÇÃO (CIP)

Serviço de Biblioteca e Informação Biomédica do

Instituto de Ciências Biomédicas da Universidade de São Paulo

(C) reprodução total

Stevanatto, Pollyana Bulgarelli.

Análise do papel das ciclooxigenases 1 e 2 na migração da linhagem celular de glioma humano U251-MG / Pollyana Bulgarelli Stevanatto. -São Paulo, 2012.

Orientador: Prof. Dr. Alison Colquhoun.

Dissertação (Mestrado) - Universidade de São Paulo. Instituto de Ciências Biomédicas. Departamento de Biologia Celular e do

Desenvolvimento. Área de concentração: Biologia Celular e Tecidual. Linha de pesquisa: Metabolismo de Células Tumorais.

Versão do título para o inglês: The role of cyclooxygenases 1 and 2 in the migration of human glioma cell line U251MG.

1. Câncer 2. Glioblastoma multiforme 3. Migração 4. Eicosanóides

5. Prostaglandina 6. Ibuprofeno I. Colquhoun, Prof. Dr. Alison II. Universidade de São Paulo. Instituto de Ciências Biomédicas. Programa de Pós-Graduação em Biologia Celular e Tecidual III. Título. 
Título da Dissertação: $\quad$ Análise do papel das ciclooxigenases 1 e 2 na migração da linhagem celular de glioma humano U251-MG.

Orientador(a): $\quad$ Prof. Dr. Alison Colquhoun.

A Comissão Julgadora dos trabalhos de Defesa da Dissertação de Mestrado, em sessão pública realizada a I....... .................., considerou

( ) Aprovado(a)

( ) Reprovado(a)

Examinador(a): Assinatura:

Nome:

Instituição:

Examinador(a): Assinatura:

Nome:

Instituição:

Presidente: Assinatura:

Nome:

Instituição: 


\section{CERTIFICADO DE ISENÇÃO}

Certificamos que o Protocolo CEP-ICB N $\mathrm{N}^{\circ} \mathbf{5 0 3 / 1 2}$ referente ao projeto intitulado: "Análise do papel das ciclooxigenases 1 e 2 na migração da linhagem de glioma bumano U251" sob a responsabilidade de Pollyana Bulgarelli Stevanatto, foi analisado na presente data pela CEUA - COMISSÃo dE ÉTICA NO USO DE ANIMAIS e pela CEPSHCOMISSÃo DE Ética EM PESQUisa COM SERES humanos, tendo sido deliberado que o referido projeto não utilizará animais que estejam sob a égide da lei 11.794 de 8 de outubro de 2008, nem envolverá procedimentos regulados pela Resolução CONEP nº196 de 1996.

São Paulo, 14 de fevereiro de 2012.

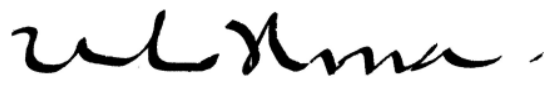

PROF. DR. WOTHAN TAVARES DE LIMA Coordenador da CEUA - ICB/USP

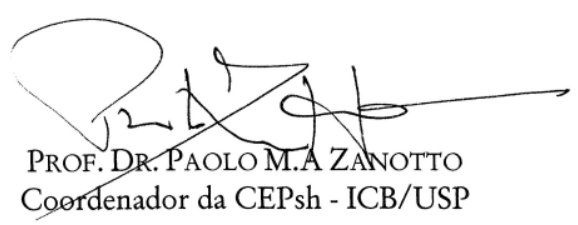


Dedico este trabalho aos meus pais, que sempre estiveram ao meu lado me apoiando em todas as minhas escolhas! E aos pacientes, que este trabalho de pesquisa básica possa Ihes trazer uma ponta de esperança para futuros tratamentos. 


\section{AGRADECIMENTOS}

À Deus, por sempre iluminar meu caminho.

À minha orientadora, Dra. Alison Colquhoun, uma chefa ímpar, um exemplo para mim. Chefa muito obrigada por ter acreditado em mim, por ter embarcado comigo nesse desafio, por todos os ensinamentos e apoio. E por muita paciência! Esse mestrado só está sendo concluído, graças ao seu apoio e incentivo, muito obrigada!

À profa. Marinilce dos Santos por todo apoio! Mari é por causa de pessoas como você e como a chefa que acredito que existem pesquisadores e educadores justos, honestos e apaixonados pelo que fazem! Muito obrigada!

Aos membros da coordenação da pós-graduação do Programa de Biologia Celular e Tecidual por todo apoio e compreensão.

Ao Tio Bauer, por todos ensinamentos, conversas e cafés, o senhor é um exemplo para mim!

Às secretárias, Celi, Ana, Regina e Elo por toda atenção, conversas e ajuda.

Aos profs. do Departamento de Biologia Celular e do Desenvolvimento por todos ensinamentos, pelas disciplinas, pela pronta ajuda sempre.

Aos meus colegas e amigos de bancada: Andrews, Andrinho, Aline, Chris, Diogo, Elo, Fábio, Fêzinha, Felipe, Keké, Lú, Marloca, Mineiro, Paola, Rê (Zé), Rê (lab) e Tati. Obrigada por serem minha família em vários momentos, pelas risadas, pelas inúmeras ajudas, pela ajuda nos experimentos, pelas comemorações, por todo apoio sempre!!!

Aos meus amigos de vida: Arthur, Dani, Dê, Fer, Jú, Lê (Famous), Romers, Sis, Tiçolina e Vitinho. Amo vocês, obrigada por sempre estarem ao meu lado!

À minha família, à minha mãe e ao meu pai, por todo amor e carinho, por me incentivarem e me darem oportunidade de realizar meu sonho! Sem dúvidas, esse mestrado é fruto do incentivo e apoio de vocês. Amo vocês, obrigada por tudo, vocês são os melhores pais e exemplo que alguém pode ter! Agradeço à minha irmã, pelo colo nas horas de aperto, pelas comemorações a cada conquista, pela casa sempre aberta a me receber, por todo amor e ajuda! Ao meu cunhado, por me receber como sua irmã, sempre pronto para me ajudar, obrigada pelas inúmeras caronas, obrigada por tudo! À minha vó, tia Cristiane e os demais pelas orações e apoio.

À Fundação de Amparo à Pesquisa do Estado de São Paulo (FAPESP) e ao CNPq, pelo suporte financeiro. 
"Você nunca sabe a força que tem. Até que a sua única alternativa é ser forte." 


\section{RESUMO}

Stevanatto PB. Análise do papel das ciclooxigensases 1 e 2 na migração da linhagem celular de glioma humano U251-MG. [dissertação (Mestrado em Biologia Celular e Tecidual)]. São Paulo: Instituto de Ciências Biomédicas, Universidade de São Paulo; 2012.

O glioblastoma multiforme (GBM) é um dos gliomas mais comuns, classificado como um glioma de grau IV (Organização Mundial da Saúde - OMS) e notoriamente difícil de ser tratado. $O$ tratamento recomendado consiste na ressecção cirúrgica seguida de radio e quimioterapia, e a sobrevida média dos pacientes é de apenas 12 meses após o diagnóstico. Portanto, novas terapias que focam a redução do volume do tumor e o aumento da morte das células tumorais são urgentemente necessárias. Estudos pré-clínicos sugerem que a inibição de COX-1 e 2 com Anti-inflamatórios não esteroidais (AINEs), como o Ibuprofeno (IBP), inibiram significantemente a proliferação e a migração celular em diferentes tumores. Assim, o presente estudo teve como objetivo avaliar in vitro o efeito da inibição de COX-1 e COX-2 através do tratamento com IBP, e também com inibidores específicos como SC-560 e NS-398 respectivamente, na migração e na proliferação da linhagem celular de glioma humano U251-MG. O presente estudo demonstrou através de diversos ensaios que a inibição de COX-1 e COX-2 através do IBP, do SC-560 e do NS-398 inibiu significativamente a migração e a proliferação celular da linhagem celular U251-MG. Dessa maneira, concluímos que a PGE2 está envolvida na migração e proliferação das células desta linhagem.

Palavras-chave: Glioma. U251-MG. Ibuprofeno. NS-398. SC-560. Migração. Proliferação. 


\begin{abstract}
Stevanatto PB. The role of cyclooxygenases 1 and 2 in the migration of human glioma cell line U251MG. [Masters thesis (Tissue and Celular Biology)]. São Paulo: Instituto de Ciências Biomédicas, Universidade de São Paulo; 2012.

Glioblastoma Multiforme (GBM) is the most common glioma, classified as grade IV (World Health Organization - WHO) and is notoriously difficult to treat. The recommended treatment consists of surgery followed by radiotherapy and chemotherapy, and the median survival is ten to twelve months. Preclinical studies suggest that inhibition of cyclooxygenase-2 by treatment with non-steroidal antiinflammatory drugs, such as ibuprofen, significantly blocked the proliferation of different tumors including gliomas. Thus this study aimed to evaluate the migration of glioma cell line U251-MG after inhibition of cyclooxygenases 1 and 2 by treatment with ibuprofen (IBP), and specific inhibitors such as SC-560 for COX-1 and NS-398 for COX-2. The present study demonstrated by various assays that inhibition of COX1 and COX-2 by IBP, SC-560 and NS-398, significantly inhibited migration and cell proliferation of the U251-MG cell line. Thus, we conclude that PGE2 is involved in this cell line's migration and proliferation.
\end{abstract}

Keywords: Glioma. U251-MG. Ibuprofen. NS-398. SC-560. Migration. Proliferation. 


\section{LISTA DE ABREVIATURAS E SIGLAS}

AA - Ácido araquidônico

AINEs - Antiinflamatórios não esteroidais

AMPc - Monofosfato de adenosina cíclico

AKT - Proteína quinase B

AS - Antisense (primer)

Bad - Proteína antagonista da Bcl-2

Bcl-2 - Célula de linfoma - 2

${ }^{\circ} \mathrm{C}-$ Graus Celsius

cDNA - DNA complementar

cm - centímetros

$\mathrm{CO}_{2}$ - Gás carbônico

COX- Ciclooxigenase

DMEM - Dulbecco's modified eagle medium

DEPC - Dietilpirocarbonato

DMSO - Dimetilsulfóxido

DNA - Ácido desoxirribonucleico

EDTA - Ácido etilenodiamino tetra-acético

EGF - Fator de crescimento epidermal

EP1 - Receptor 1 de $\mathrm{PGE}_{2}$

EP2 - Receptor 2 de $\mathrm{PGE}_{2}$

EP3 - Receptor 3 de $\mathrm{PGE}_{2}$

EP4 - Receptor 4 de $\mathrm{PGE}_{2}$ 
GAPDH - Gliceraldeído 3 fosfato desidrogenase

GBM - Glioblastoma multiforme

HETEs - Ácidos hidroxieicosatetraenóicos

IBP - Ibuprofeno

INCA - Instituto nacional do câncer

IP3 - Trifosfato de inositol

$\mathrm{KDa}$ - Kilodalton

LOX - Lipooxigenase

LPS - Lipopolissacarídeo

M - Molar

Mcl-1 - Proteína de diferenciação celular de leucemia mielóide crônica

$\mathrm{mL}-$ Mililitros

$\mathrm{mM}$ - Milimolar

MMPs - Metaloproteinases de matriz

RNAm - RNA mensageiro

$\mu \mathrm{M}$ - Micromolar

NF-KB - Fator nuclear kappa B

OMS - Organização mundial da saúde

P.A. - Para análise

pb - Pares de bases

PBS - Tampão fosfato salino

PCR - Reação em cadeia da polimerase

PI3-AKT - Fosfatidilinositol 3 quinase - proteína quinase B

PKC - Proteína quinase C 
PGs - Prostaglandinas

$\mathrm{PGE}_{2}-$ Prostaglandina $\mathrm{E}_{2}$

$\mathrm{PGG}_{2}-$ Prostaglandina $\mathrm{G}_{2}$

PUFAs - Ácidos graxos poliinsaturados

RNA - Ácido ribonucleico

ROS - Espécies reativas de oxigênio

RPM - Rotações por minuto

RT-PCR - Reação em cadeia da polimerase pela transcriptase reversa

SDS - Dodecil sulfato de sódio

SFB - Soro fetal bovino

TBS - Tampão tris salino

$\mathrm{TXA}_{2}-$ Tromboxano $\mathrm{A}_{2}$

VEGF - Fator de crescimento vascular endotelial 


\section{LISTA DE ILUSTRAÇÕES}

Figura 1 - Esquema de evolução de malignidade dos gliomas...............................20

Figura 2 - Cascata de metabolização do ácido araquidônico pela via de COX........23

Figura 3 - Curva de dose-resposta do tratamento com IBP ..................................36

Figura 4 - Imagens da curva de dose-resposta do tratamento com IBP em 48

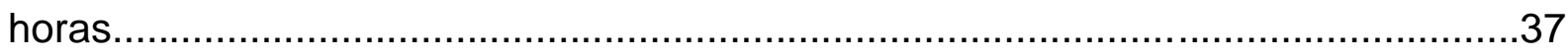

Figura 5 - Curva de dose-resposta do tratamento com SC-560..............................38

Figura 6 - Imagens da curva de dose-resposta do tratamento com SC-560 em 48 horas.

Figura 7 - Curva de dose-resposta do tratamento com NS-398............................40

Figura 8 - Imagens da curva de dose-resposta do NS-398 em 48 horas..................41

Figura 9 - Cura de dose-resposta do tratamento com AH6809............................42

Figura 10 - Curva de dose-resposta do tratamento com L161.982.......................43

Figura 11 - Expressão gênica de COX-1 ..............................................................

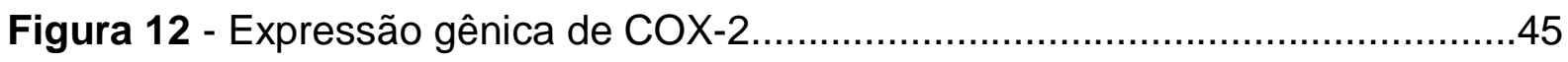

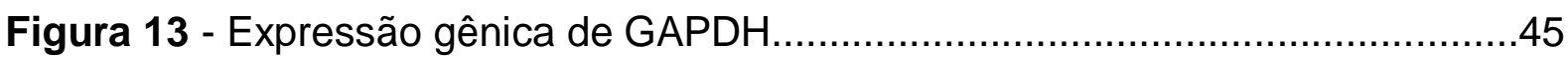

Figura 14 - Expressão gênica dos receptores EPs na linhagem U251-MG..............46

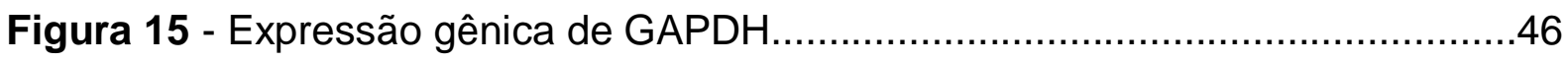

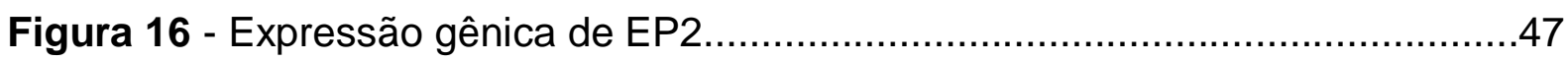

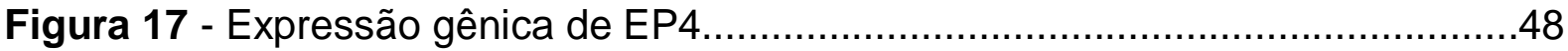

Figura 18 - Expressão proteica de COX-1 e COX-2 no tratamento com IBP.............49

Figura 19 - Expressão proteica de COX-1 e COX-2 no tratamento com SC-560.....50

Figura 20 - Expressão proteica de COX-1 e COX-2 no tratamento com NS-398.....51 
Figura 21 - Expressão proteica dos EPs na linhagem celular U251-MG.

Figura 22 - Expressão de EP2 no tratamento com AH6809, SC-560, NS-398 e IBP

Figura 23 - Expressão de EP4 no tratamento com AH6809, SC-560, NS-398 e IBP

Figura 24 - Gráfico da migração celular após o tratamento com IBP, SC560 e NS398.

Figura 25 - Imagens da migração celular após o tratamento com IBP, SC-560 e NS398.

Figura 26 - Gráfico da migração celular pelo período de 12 horas .55

Figura 27 - Imagens da migração celular pelo período de 12 horas. .56

Figura 28 - Gráficos de análise do ciclo celular dos tratamentos com IBP, SC-560 e NS-398

Figura 29 - Porcentagem de células em cada fase do ciclo celular. 58

Figura 30 - Gráficos de análise do ciclo celular dos tratamentos com L161.982 e AH6809.

Figura 31 - Porcentagem de células em cada fase do ciclo celular. 60

Figura 32 - llustração demonstrando os principais resultados deste estudo 66 


\section{LISTA DE TABELAS}

Tabela 1 - Sequência dos primers utilizados para análise da expressão gênica.....30

Tabela 2 - Ensaios de Migração por Transwell..................................................55

Tabela 3 - Porcentagem de células em cada fase do ciclo celular............................57

Tabela 4 - Porcentagem de células em cada fase do ciclo celular..........................59 


\section{SUMÁRIO}

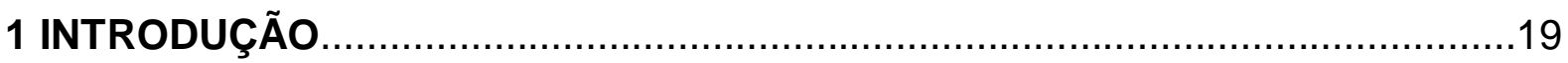

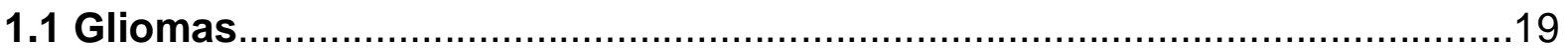

1.2 Metabolização do ácido araquidônico e as ciclooxigenases......................21

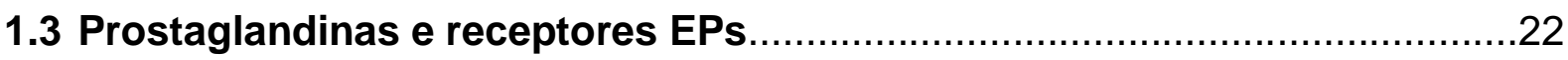

1.4 Antiinflamatórios não esteroidais (AINEs) e o câncer...............................25

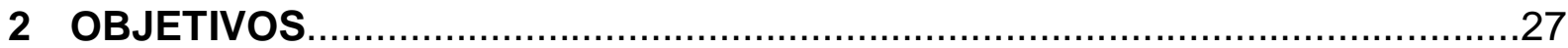

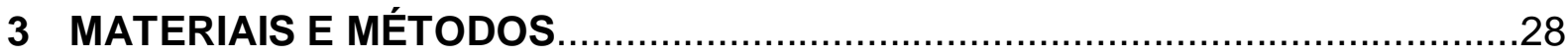

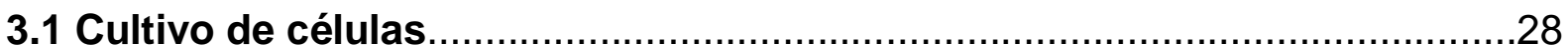

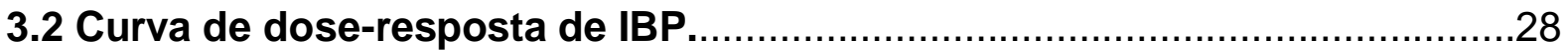

3.3 Curva de dose-resposta de SC-560, inibidor específico de COX-1; e NS-398,

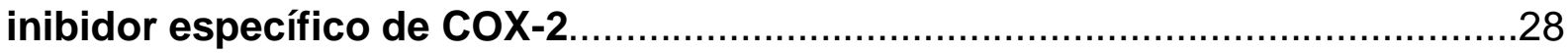

3.4 Curva de dose-resposta de AH6809, antagonista de EP2; e de L161.982, antagonistas de EP4

3.5 Análise da expressão gênica através de RT-PCR semi-quantitativo...........29

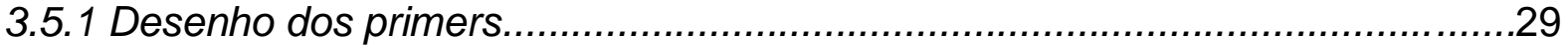

3.5.2 Tratamento das células....................................................................... 30

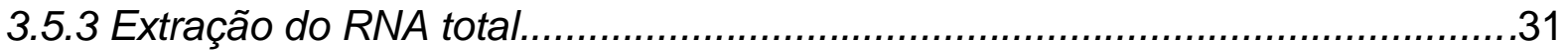

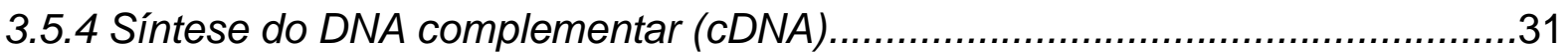

3.5.5 Reação em cadeia da polimerase (PCR) ...................................................31

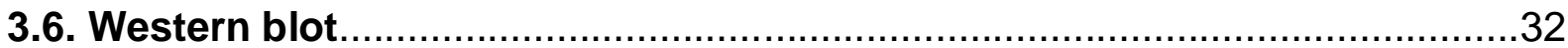

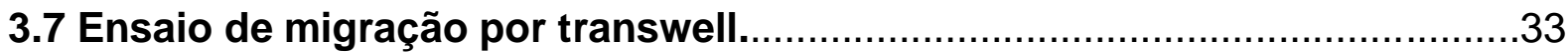

3.8 Análise do ciclo celular por FACS-PI (fluorescent activated cell sorting com

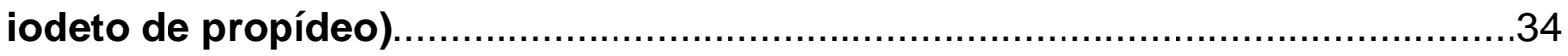


3.9 Análise estatística.

4 RESULTADOS. 36

4.1 Curva de dose-resposta de Ibuprofeno.

4.2 Curva de dose-resposta de SC-560

4.3 Curva de dose-resposta do NS-398. 39

4.4 Curva de dose-resposta do AH6809

4.5 Curva de dose-resposta do L161.982.

4.6 Análise da expressão gênica através de RT-PCR semi-quantitativo.

4.6.1 Análise da expressão gênica de COX-1 e COX-2 na linhagem celular U251MG

4.6.2 Análise da expressão gênica de EP1, EP2, EP3 e EP4 na linhagem celular U251-MG.

4.7 Western blot. .48

4.7.1 Expressão proteica de COX-1 e COX-2..................................................48

4.7.2 Expressão proteica de EP1, EP2, EP3 e EP4 ......................................51

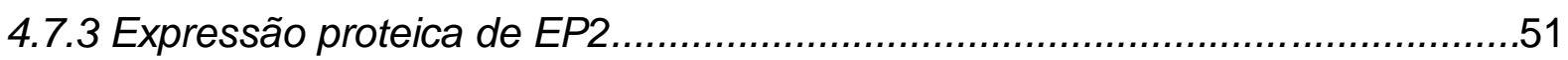

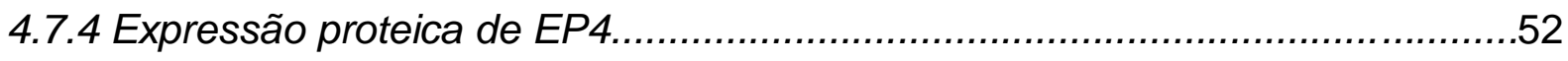

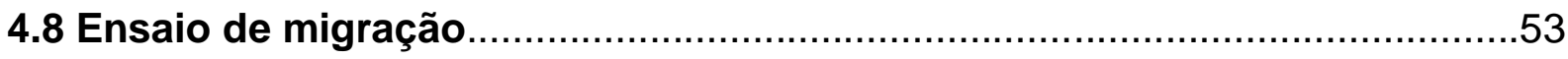

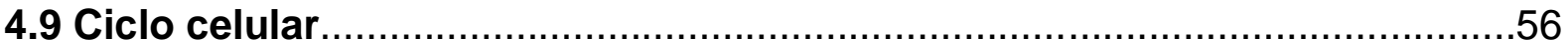

4.9.1 Análise do ciclo celular para os tratamentos com IBP, SC-560 e NS398. .56

4.9.2 Análise do ciclo celular para os tratamentos com AH6809 e L161.982. .58 
6 CONCLUSÃO.

REFERÊNCIAS

.68 


\section{INTRODUÇÃO}

\subsection{Gliomas}

Os gliomas são os tumores mais comuns do sistema nervoso central, de acordo com o Instituto Nacional do Câncer (INCA) representam cerca de $2 \%$ dos tumores que acometem a população brasileira (INCA, 2009). Apesar de serem considerados uma neoplasia maligna rara, com pouca incidência em relação aos demais tipos de câncer, os gliomas se destacam por apresentarem altos índices de mortalidade.

Dentre os gliomas, os tumores derivados dos astrócitos são os mais prevalentes, denominados de astrocitomas, os quais apresentam uma significante heterogeneidade histopatológica. Devido a essa característica a Organização Mundial da Saúde (OMS) os classifica de acordo com os diferentes graus de malignidade, de I a IV (Lima et al., 2012). O astrocitoma pilocítico (grau I), é caracterizado pela presença de astrócitos bipolares com longos prolongamentos. Os astrocitomas difusos (grau II) apresentam atipia nuclear, e o astrocitoma anaplásico (grau III) é caracterizado por altas taxas de mitose (Louis et al., 2007). Já o Glioblastoma Multiforme (GBM) é classificado como um astrocitoma de grau IV, e se destaca entre os demais pela sua rápida proliferação celular, agressiva invasão do tecido cerebral e a formação de focos de necrose (Chiu et al., 2010). 
Figura 1 - Esquema de evolução de malignidade dos gliomas

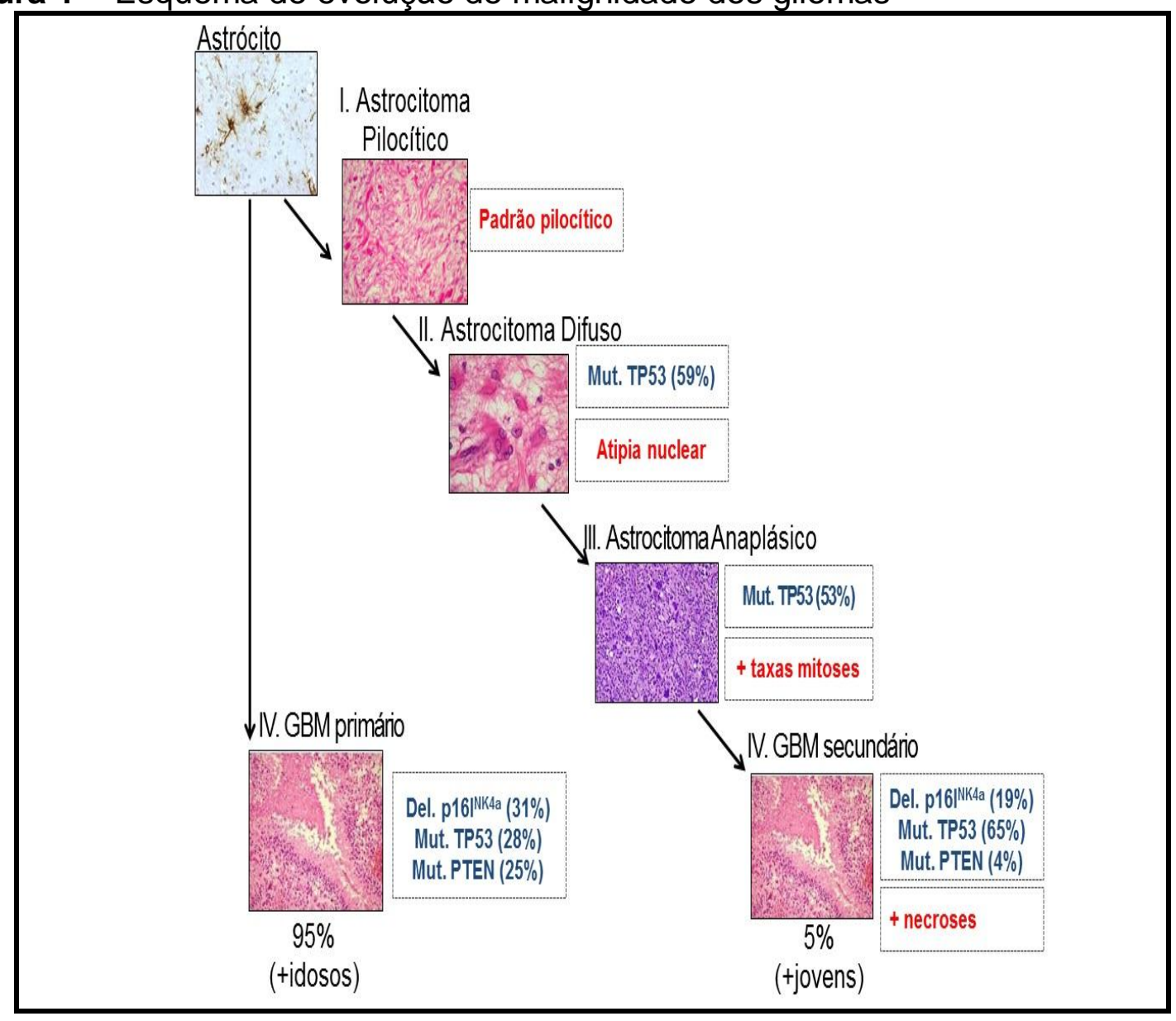

O GBM é derivado de transformações malignas de células maduras da glia ou de células-tronco neurais (Helseth et al., 2010; Kleihues et al., 1993). É altamente angiogênico, pois a neo-formação dos vasos que o nutrem é decorrente da população de células-tronco do próprio tumor (Ricci-Vitiani et al., 2010). Ele pode ser classificado em dois subtipos diferentes, glioblastoma primário e secundário, de acordo com a sua origem histológica. Os GBMs primários representam cerca de 90\% dos casos, se desenvolvem rapidamente sem evidências clínicas ou histopatológicas e acometem principalmente indivíduos acima de 60 anos. Já os GBMs secundários desenvolvem-se através da progressão de um glioma de baixo grau, como astrocitoma difuso ou anaplásico, e acometem indivíduos mais jovens, na faixa etária dos 45 anos (Ohgaki, Kleihues, 2007).

Em ambos os casos, a sobrevida dos pacientes é muito pequena, apenas de doze a quinze meses após o diagnóstico, embora existam alguns casos, que representam cerca de 3 a 5\%, de sobrevida maior que três anos (Das et al., 2011).

O tratamento recomendado consiste na combinação da ressecção cirúrgica do tumor cerebral, visando ampla remoção da massa tumoral e preservação das 
funções neurológicas; seguida de radioterapia e, em alguns casos, concomitante e adjuvante quimioterapia com temozolomida (Buonerba et al., 2010; Clarke et al., 2010). Porém, a total recessão cirúrgica nem sempre é possível, já que o tumor pode estar localizado em uma área vital ou de funções neurológicas fundamentais, portanto nesse caso é realizado apenas a cito-redução do tumor ou biópsia da lesão (Rich, Bigner, 2004).

Apesar dos avanços da neurocirurgia, quimio e radioterapia, não foi observado melhora na terrível estatística clínica do GBM. Essas terapias convencionais são inerentes às propriedades intrínsecas das células deste tumor, que são altamente infiltrativas, o que evita a sua recessão total, além de serem resistentes à quimioterapia e radioterapia.

Portanto, novas terapias que focam na redução do volume do tumor e no aumento da morte das células tumorais são urgentemente necessárias (Barzon et al., 2006).

\subsection{Metabolização do ácido araquidônico e as ciclooxigenases}

Os ácidos graxos essenciais são os ácidos graxos que não são sintetizados pelo organismo, e portanto são obtidos através da dieta. São poliinsaturados (PUFAs), ou seja, possuem mais que duas duplas ligações de carbono em sua estrutura (Benadiba, 2008); e são conhecidos por inibirem a proliferação celular de muitos tipos de tumores tanto in vitro quanto in vivo. Sua capacidade de interferir na proliferação celular está associada a sua indução de produção de espécies reativas de oxigênio (ROS) nas células tumorais resultando em morte celular por apoptose (Colquhoun, 2010).

O ácido araquidônico (AA) é um dos PUFAs mais encontrado na gordura animal, estudos apontam que a sua metabolização tem um papel crucial na inflamação crônica e no câncer. O AA pode ser metabolizado por três vias enzimáticas distintas, podendo ser substrato para a ciclooxigenase (COX), lipoxigenase (LOX) e pela via P450 da epoxigenase, resultando na produção dos eicosanóides, que incluem os prostanóides, os leucotrienos e os ácidos hidroxieicosatetraenóicos (HETEs), respectivamente (Carneiro et al., 2004; Wang, DuBois, 2010). 
Os eicosanóides são lipídeos biologicamente ativos que apresentam implicações em diversos processos patológicos, como a inflamação e o câncer. São capazes de promover a sobrevivência, a proliferação e a motilidade celular através da modulação da angiogênese, da adesão celular, da permeabilidade vascular e da inflamação (Miyake, 2009; Nathoo et al., 2004). Estudos têm mostrado que a ativação de COX e LOX durante a inflamação crônica e a carcinogênese resulta em um metabolismo anormal do $\mathrm{AA}$, que pode ser relacionado com a transformação celular e a promoção tumoral (Wang, DuBois, 2010).

As COXs possuem três isoformas, incluindo a isoforma constitutiva, COX-1, e as isoformas induzidas, COX-2 e COX-3. COX-1 é constitutivamente expressa na maioria dos tecidos, é o catalisador da síntese da prostaglandina, a qual é necessária para o desempenho normal de algumas funções fisiológicas, como a agregação plaquetária e a citoproteção. Por outro lado, COX-2 é expressa constitutivamente em neurônios e no rim, contudo também pode ser rapidamente induzida por vários fatores como lipopolisacarídeos (LPS), fator de crescimento epidérmico (EGF) e ácido lipoteicóico (Chen et al., 2001; Xu et al., 2009).

$\mathrm{Na}$ presença de gliomas, a expressão de COX-2 foi identificada tanto nas células tumorais, quanto nos vasos que nutrem o tumor (Müller-Decker, Fürstenberger, 2007). Sua expressão também foi detectada em tecidos pré-malignos e malignos, portanto sugere-se que as COXs, particularmente COX-2, estão relacionadas com a progressão tumoral (Marshall et al., 2007).

A alta expressão e atividade de COX, principalmente COX-2, é responsável pela excessiva síntese de prostaglandina $\mathrm{E}_{2}\left(\mathrm{PGE}_{2}\right)$ e pode estar relacionada com a promoção da neoplasia, já que o aumento da expressão gênica de COX-2 foi detectada em uma variedade de tumores malignos associados com a elevada produção de $\mathrm{PGE}_{2}$.

\subsection{Prostaglandinas e receptores EPs}

As prostaglandinas (PGs) são sintetizadas a partir da hidrólise de fosfolipídeos da membrana plasmática para produção de araquidonato livre, em uma reação catalisada pela fosfolipase $A_{2}$. $O$ araquidonato livre é oxigenado pela COX, produzindo a $\mathrm{PGG}_{2}$, que é altamente instável. Esta serve como substrato para 
diversas enzimas, as $P G$ sintases, responsáveis pela produção das $P G s\left(D_{2}, E_{2}, F_{2 \alpha}\right.$ e $\mathrm{I}_{2}$ ) e tromboxano sintase (TXA $)$ (Hinz, Brune, 2002; Wang et al., 2007).

$\mathrm{Na}$ Figura 2, abaixo, é possível observar o esquema da cascata de metabolização do ácido araquidônico pela via de COX.

Figura 2 - Cascata de metabolização do ácido araquidônico pela via de COX

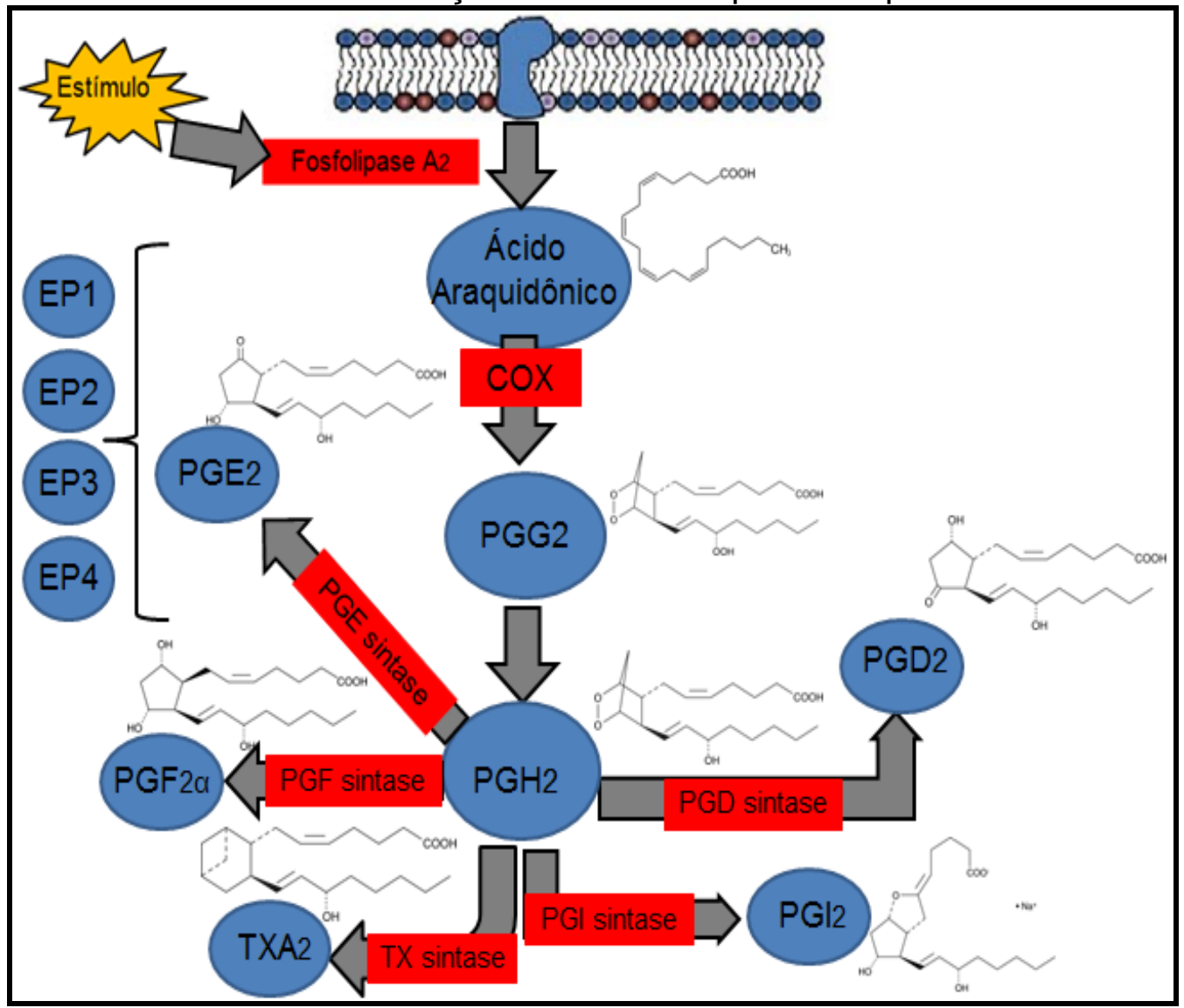

As prostaglandinas estão envolvidas em diversos processos fisiológicos e patológicos, como a inflamação, dor, funções renais, pressão sanguínea e função plaquetária, e também na progressão tumoral (Smyth et al., 2009).

Dentre as prostaglandinas, a prostaglandina E2 (PGE2) é a mais abundante e está envolvida na promoção tumoral, sendo encontrada em altos níveis em vários tipos de tumores, como o de cólon, pulmão, mama e próstata (Badawi et al., 1999; Wang, DuBois, 2012). A PGE 2 auxilia na progressão tumoral através de diversos mecanismos, como a estimulação da proliferação, sobrevivência, migração, invasão e angiogênese, e também modula a ação da resposta imune anti-tumoral (Greenhough et al., 2009).

A $\mathrm{PGE}_{2}$ está presente em diversos tumores e está relacionada com o aumento de produção de VEGF (Fator de Crescimento Vascular do Endotélio), 
proporcionando a angiogênese, aumento da migração de células endoteliais através de maior adesão à matriz extracelular, e aumento da ativação de MMPs (Matriz Metaloproteinases) que são capazes de digerir a membrana basal, proporcionando assim maior capacidade de invasão, resultando na promoção tumoral (Telliez et al., 2006). Não obstante, a $\mathrm{PGE}_{2}$ é capaz de modular a expressão de NF-KB e Mcl-1, via Pl13/AKT, ocasionando a diminuição de proteínas como as da família Bad e Bcl-2 que inibem a apoptose e promovem a sobrevivência celular (Larkins et al., 2006).

$O$ efeito de $\mathrm{PGE}_{2}$ é mediado através de quatro distintos receptores, EP1-EP4, os quais pertencem a família de receptores acoplados a proteína $G$, todos possuem caracteristicamente sete domínios transmembranas, embora cada um deles seja codificado por um gene distinto e promovam respostas celulares através da ativação de diferentes tipos de proteína $\mathrm{G}$ (Coleman et al., 1994; Miao et al., 2012).

O receptor EP1 acoplado à proteína Gaq induz a formação de trifosfatidilinositol e um subsequente aumento nos níveis de cálcio intracelular, e promove também a ativação da proteína quinase $C(P K C)$, envolvida na transdução de sinais (Miao et al., 2012). Nas células tumorais, este receptor está associado ao aumento de estímulo à proliferação e invasão destas células (Kamei et al., 2009).

Os receptores EP2 e EP4 ligam-se à proteína Gaq e regulam o aumento dos níveis de adenosina monofosfato cíclico - AMPc (Hata, Breyer, 2004). Estudos apontam que EP2 quando ativado por PGE2 pode está associado à processos de proliferação celular e diminuição de apoptose em tumores. Esta interação de $\mathrm{PGE}_{2} \mathrm{e}$ EP2 em câncer de mama sugere que estão envolvidos com mecanismos de angiogênese e carcinogênese (Fujino et al., 2002; Sung et al., 2005).

Contudo, o receptor EP4 também pode ativar a via de PI3K/Akt, através da sua ligação com a proteína Gai. Esta via de sinalização está relacionada com a tumorigênese, já que a proteína Akt modula a função de vários substratos envolvidos na regulação da sobrevivência, progressão e crescimento celular (Vara et al., 2004). Estudos em câncer de mama sugerem que a via $\mathrm{PGE}_{2}$-EP4 tem efeitos metastáticos, porém com a adição de antagonistas para este receptor, este efeito foi inibido (Kundo et al., 2008).

O receptor EP3 possui três diferentes isoformas na região c-terminal, EP3a, EP3 $\beta$ e EP3y. As três isoformas ligam-se à proteína Gai, e reduzem os níveis de AMPc e atuam sobre inositol trifosfato (IP3), aumentando os níveis de cálcio. Já as duas primeiras isoformas (EP3a, EP3 $\beta$ ) podem ligar-se também à proteína Gas, mas 
nesse caso, aumentando os níveis de AMPc (Dorsm, Gutkind, 2007; Sugimoto, Narumiya, 2007). Estudos em células tumorais de sarcoma apontam que o envolvimento de $\mathrm{PGE}_{2}$-EP3 parece influenciar a proliferação e a angiogênese nessas células (Amano et al., 2003).

\subsection{Antiinflamatórios não esteroidais (AINEs) e o câncer}

Os antiinflamatórios não esteroidais (AINEs) constituem um grupo de variados fármacos de amplo espectro terapêuticos, são antiinflamatórios, analgésicos e antipiréticos (Kummer, Coelho, 2002).

A relação entre o uso dos AINEs e o câncer se deu a partir de diversos estudos epidemiológicos que apontaram o uso prolongado desses medicamentos e a redução de diversos tipos de tumores como câncer gástrico, de colorretal, de mama, de pulmão e de próstata (Baron, Sandle, 2000; Johnson et al., 2010; Ulrich et al., 2006). Os mecanismos envolvidos nesse processo ainda não estão completamente elucidados, mas estudos mostram que os AINEs inibem inespecificamente as COXs, suprimindo assim a síntese das prostaglandinas, e dessa forma afetam a proliferação celular, migração, angiogênese e apoptose (Gallo et al., 2002).

Dentre os AINEs, se destaca o ibuprofeno (IBP), um fármaco derivado do ácido propiônico, um dos grupos mais importantes de antiinflamatórios não esteróides. É um dos pioneiros desse grupo a ser administrado e até os dias de hoje é amplamente utilizado. Seu mecanismo de ação, assim como os demais AINEs, está atribuído à inibição não seletiva de COXs, conforme descrito anteriormente (Newa et al., 2008).

Estudos apontam o uso de IBP na redução do risco de câncer de próstata e em mecanismos relacionado com a morte de células deste tipo de tumor (Andrew et al., 2002; Mahmud et al., 2010). Estudos utilizando o IBP em células C6 de gliomas de ratos in vivo, demonstraram que essa droga é capaz de reduzir o peso do tumor alterando o seu padrão angiogênico, além da supressão de vasos peritumorais (Altinoz et al., 2001; Farrel et al., 1988).

Não obstante, estudos pré-clínicos sugeriram que a inibição de COX-2 e a diminuição da $\mathrm{PGE}_{2}$ com uso de AINEs bloquearam significantemente a proliferação de diferentes tumores, incluindo câncer gástrico e em algumas linhagens de 
glioblastoma multiforme, promoveram invasão menos eficiente e migração celular reduzida (Lim et al., 2001; Wakimoto et al., 2008). 


\section{OBJETIVOS}

Este trabalho teve como objetivo analisar o efeito da inibição de COX-1 e COX-2 na migração e proliferação da linhagem celular de glioma humano U251-MG.

1) Determinar os efeitos da adição de IBP, inibidor não seletivo de COX-1 e COX-2, na migração e proliferação das células U251-MG;

2) determinar os efeitos da adição de SC-560, inibidor seletivo de COX-1, na migração e proliferação das células U251-MG;

3) determinar os efeitos da adição de NS-398, inibidor seletivo de COX-2, na migração e proliferação das células U251-MG;

4) determinar os efeitos da adição de AH6809, antagonista do receptor EP2, na proliferação e expressão gênica e proteica das células U251-MG;

5) determinar os efeitos da adição de L161.982, antagonista do receptor EP4, na proliferação das células U251-MG;

6) determinar a influência dos tratamentos mencionados acima da expressão gênica e proteica de COX-1, COX-2, EP2 e EP4. 


\section{MATERIAIS E MÉTODOS}

\subsection{Cultivo de células}

As células da linhagem U251-MG de glioma humano, gentilmente cedidas pela Dra. Eugenia Costanzi-Strauss do Instituto de Ciências Biomédicas da Universidade de São Paulo; foram cultivadas em garrafas plásticas estéreis, contendo meio DMEM, Dulbecco's Modified Eagle Medium, (Invitrogen, CA - EUA), suplementado com $10 \%$ de soro fetal bovino (SFB) e antibióticos, penicilina $50 \mathrm{ug} / \mathrm{ml}$ e estreptomicina $50 \mu \mathrm{g} / \mathrm{ml}$. Foram mantidas em estufa em atmosfera com $5 \%$ de $\mathrm{CO}_{2}$ e temperatura de $37^{\circ} \mathrm{C}$.

\subsection{Curva de dose-resposta de IBP}

Foi realizada a curva de dose-resposta para verificar a influência do tratamento com lbuprofeno (IBP) em diferentes concentrações e períodos de tratamentos sobre a linhagem celular U251-MG.

Foram plaqueadas $2 \times 10^{4}$ células por poço, em placas de 24 poços, e tratadas por 24 e 48 horas com as seguintes concentrações de IBP: $25 \mu \mathrm{M}, 50 \mu \mathrm{M}, 75 \mu \mathrm{M}$ e $100 \mu \mathrm{M}$.

Utilizou-se como controle o veículo da droga, etanol P.A., no mesmo volume utilizado na concentração máxima do tratamento, cuja concentração foi de $1 \%$ no volume total de meio de cultivo utilizado. Além disso, também se utilizou um controle que não recebeu nenhum tratamento. Após cada período de tratamento, as células foram tripsinizadas (Tripsina 0,025\% em ácido etilenodiamino tetra-acético - EDTA, $0,02 \%$ ) e contadas em câmara de Neubauer. Todas as análises foram realizadas em triplicatas.

\subsection{Curva de Dose-Resposta de SC-560, inibidor específico de COX-1; e NS- 398 , inibidor específico de COX-2}

Para verificar a influência do tratamento com os inibidores específicos de COX-1 e COX-2, SC-560 e NS-398 respectivamente, sobre a linhagem celular U251- 
MG foram realizadas curvas de dose-resposta das drogas em diferentes concentrações e períodos de tratamentos.

Foram plaqueadas $2 \times 10^{4}$ células por poço, em placas de 24 poços e tratadas por 24 e 48 horas com as seguintes concentrações de SC-560 e NS-398: $50 \mu \mathrm{M}$, $100 \mu \mathrm{M}$ e $150 \mu \mathrm{M}$. Utilizou-se como controle o veículo da droga, dimetilsulfóxido (DMSO) no mesmo volume utilizado na concentração máxima do tratamento, cuja concentração foi de $0,27 \%$ no volume total de meio de cultivo utilizado. Além disso, também se utilizou um controle que não recebeu nenhum tratamento.

Em cada período, as células foram tripsinizadas (Tripsina 0,025\% em EDTA 0,02\%) e contadas em câmara de Neubauer. Todas as análises foram realizadas em triplicatas.

\subsection{Curva de Dose-Resposta de AH6809, antagonista de EP2; e de L161.982, antagonista de EP4}

Para verificar a influência do tratamento com os antagonistas dos receptores EP2 e EP4, AH6809 e L161.982 respectivamente, sobre a linhagem celular U251MG foram realizadas curvas de dose-resposta das drogas em diferentes concentrações e períodos de tratamentos.

Foram plaqueadas $2 \times 10^{4}$ células por poço, em placas de 24 poços e tratadas por 24 e 48 horas com as seguintes concentrações de AH6809 e L161.982: 0,1 $\mu \mathrm{M}$, $1 \mu \mathrm{M}$ e $10 \mu \mathrm{M}$. Utilizou-se como controle o veículo da droga, DMSO no mesmo volume utilizado na concentração máxima do tratamento, cuja concentração foi de $0,6 \%$ no volume total de meio de cultivo utilizado. Além disso, também se utilizou um controle que não recebeu nenhum tratamento.

Em cada período, as células foram tripsinizadas (Tripsina 0,025\% em EDTA 0,02\%) e contadas em câmara de Neubauer. Todas as análises foram realizadas em triplicatas.

\subsection{Análise da expressão gênica através de RT-PCR semi-quantitativo}

\subsubsection{Desenho dos primers}


Os primers utilizados para a reação de RT-PCR seguem na tabela 1, e foram desenhados com base em sequências disponíveis no GenBank (www.ncbi.nlm.nih.gov) e com o auxílio do programa Primer 3 (www.genome.wi.mit.edu/cgi-bin/primer/primer3 wwwcgi), suas especificidades foram analisadas por BLAST (http://blast.ncbi.nlm.nih.gov/Blast.cgi). Todos os primers utilizados neste trabalho foram sintetizados pela Invitrogen, CA - EUA.

Tabela 1 - Sequência dos Primers Utilizados para Análise da Expressão Gênica

\begin{tabular}{|c|c|c|c|}
\hline Genes & Sequências $\left(5^{\prime}-3^{\prime}\right)$ & Tamanho do Produto (pb) & Temperatura de Anelamento ( $\left.{ }^{\circ} \mathrm{C}\right)$ \\
\hline COX-1 & $\begin{array}{l}\text { S: CCTCATGTTTGCCTTCTTTGC } \\
\text { AS: GGCGGGTACATTTCTCCATC }\end{array}$ & 168 & 63 \\
\hline cox-2 & $\begin{array}{l}\text { S: ATCTACCCTCCTCAAGTCCC } \\
\text { AS: TACCAGAAGGGCAGGATACGA }\end{array}$ & 670 & 69 \\
\hline GAPDH & $\begin{array}{l}\text { S: GAGTCAACGGATTTGGTCGT } \\
\text { AS: TTGATTTTGGAGGGATCTCG }\end{array}$ & 250 & 52 \\
\hline EP1 & $\begin{array}{l}\text { S: AGCATCTGGCTGTCTAGAATGT } \\
\text { AS: CAAGGATGCCAGCAGAAAGTC }\end{array}$ & 121 & 61 \\
\hline EP2 & $\begin{array}{l}\text { S: GCACCGAGACAATGAGAAGCA } \\
\text { AS: GCAGTCCCTGCTCTTCTGC }\end{array}$ & 110 & 59 \\
\hline EP3 & $\begin{array}{l}\text { S: TCATGATAGAGAACCCTGCAGT } \\
\text { AS: ATCCCAGGGTTAGGCAGATTTA }\end{array}$ & 332 & 51 \\
\hline EP4 & $\begin{array}{l}\text { S: GCTTTCACCTTGTCCTGCTC } \\
\text { AS: AAGCTGGGACTCGTCTTTGA }\end{array}$ & 171 & 59 \\
\hline
\end{tabular}

\subsubsection{Tratamento das células}

Foram plaqueadas $2 \times 10^{5}$ células em garrafas plásticas de $25 \mathrm{~cm}^{2}$, em triplicatas para cada tratamento, e foram tratadas com $50 \mu \mathrm{M}$ de IBP, SC-560 e NS398 e com $10 \mu \mathrm{M}$ de AH6809 e L161.982 por 48 horas. Foram utilizados como controles, amostras que não recebeu nenhum tratamento, amostras tratadas com etanol P.A., veículo do IBP; e amostras tratadas com DMSO, veículo dos inibidores específicos. 


\subsubsection{Extração do RNA total}

Ao término do tratamento as células foram coletadas, mantidas em gelo e homogeneizadas em equipamento Politron PT - 3100 (Kinematica Dispersing and Mixing Technology, Luzern - Suíça) com $1 \mathrm{~mL}$ de Trizol $^{\circledR}$ (Invitrogen, CA - EUA); e foram mantidas em temperatura ambiente por 5 minutos. Foram adicionados $200 \mathrm{uL}$ de clorofórmio, e centrifugadas a 10600 RPM por $15^{\prime}$ à $4{ }^{\circ} \mathrm{C}$. A fase aquosa, o sobrenadante, foi retirado e transferido para um novo tubo, ao qual foi adicionado $500 \mathrm{uL}$ de isopropanol gelado, as amostras foram centrifugadas a 10600 RPM por 10 minutos a $4{ }^{\circ} \mathrm{C}$. O sobrenadante foi descartado e o precipitado foi lavado com 1 $\mathrm{mL}$ de etanol $75 \%$ livre de RNAse, e centrifugado a 7500 RPM por 5 minutos a $4 \stackrel{\circ}{\circ}$. Essa etapa de lavagem foi realizada duas vezes. Por fim, o sobrenadante foi removido, o precipitado de RNA foi ressuspendido em 50 uL de água DEPC (dimetil pirocarbonato).

O RNA foi quantificado em equipamento Nano-Drop, utilizando a relação A260/A280 $\geq 1,8$. O RNA foi mantido a $-80{ }^{\circ} \mathrm{C}$. E a integridade do RNA foi verificada por eletroforese em gel de agarose a $1 \%$ contendo brometo de etídio.

\subsubsection{Síntese do DNA complementar (cDNA)}

A síntese do cDNA foi realizada por RT-PCR utilizando a enzima MMLVtranscriptase reversa (Invitrogen, $C A-E U A$ ), utilizando 3 ug do RNA de interesse e de acordo com as instruções do fabricante. A integridade do cDNA foi analisada por eletroforese em gel de agarose $1 \%$ contendo brometo de etídio.

\subsubsection{Reação em Cadeia da Polimerase (PCR)}

Cada reação de PCR foi preparada para um volume final de $30 \mathrm{uL}$, contendo: 16 uL de $\mathrm{H}_{2} \mathrm{O}$ MilliQ autoclavada, 3 uL de $10 x \mathrm{PCR}$ Rxn Buffer $-\mathrm{MgCl}_{2}$ (Invitrogen, $C A$ - EUA), 1 uL dNTP mix (10 mM), 1,5 uL $\mathrm{MgCl}_{2}$ (50 mM, Invitrogen, CA-EUA), 3 $\mathrm{uL}$ primer sense $(10 \mu \mathrm{M}), 3 \mathrm{uL}$ primer antisense $(10 \mu \mathrm{M}), 2 \mathrm{uL}$ cDNA e $0,5 \mathrm{uL}$ Platinum Taq DNA Polymerase (Invitrogen, CA - EUA).

As condições da reação foram: $94 \stackrel{\circ}{\mathrm{C}}$ por 1 minuto, temperatura específica de cada primer de interesse por 1 minuto e $72{ }^{\circ} \mathrm{C}$ por 1 minuto, por 40 ciclos. A 
amplificação da reação foi confirmada por eletroforese em gel de agarose $1 \%$ contendo brometo de etídeo. O gene GAPDH foi utilizado como controle endógeno de expressão constitutiva. Todas as análises foram realizadas em triplicatas.

A análise semi-quantitativa do produto da reação foi realizada utilizando 0 programa Image $\mathrm{J}$.

\subsection{Western blot}

Foram plaqueadas $2 \times 10^{5}$ células em garrafas plásticas de $25 \mathrm{~cm}^{2}$, em triplicatas para cada tratamento, o tratamento foi realizado com $50 \mu \mathrm{M}$ de IBP, SC560 e NS-398 e com $10 \mu \mathrm{M}$ de AH6809 e L161.982 por 48 horas. Foram utilizados como controles, amostras que não receberam nenhum tratamento, amostras tratadas com etanol P.A., veículo do IBP; e amostras tratadas com DMSO, veículo dos inibidores específicos e dos antagonistas.

As células foram tripsinizadas (Tripsina 0,025\% em EDTA 0,02\%), centrifugadas a 1500 RPM (rotação por minuto) por dois minutos, e lavadas com PBS 1X. A proteína foi extraída com tampão de lise (10 mM Tris, $100 \mathrm{mM} \mathrm{NaCl} ; 1$ mM EDTA e 1\% Triton X-100 - pH 7.6), inibidor de protease e inibidor de fosfatase utilizando um pilão de vidro de $1 \mathrm{~mL}$. A concentração proteica foi determinada através do método de Lowry. Os extratos proteicos foram diluídos em tampão de amostra (1,51g de Tris- $\mathrm{HCl}$ - pH6,8, $40 \mathrm{~mL}$ de SDS 10\%, $10 \mathrm{~mL}$ de mercaptoetanol, $20 \mathrm{~mL}$ de glicerol, $0,004 \mathrm{~g}$ de azul de bromofenol em $100 \mathrm{~mL}$ de $\mathrm{H}_{2} 0$ destilada) e incubados a $100 \stackrel{\circ}{\circ}$ por 3 minutos.

O processo de separação foi realizado por eletroforese em gel stacking SDSPAGE com 4\% de acrilamida, acompanhado de um segundo gel de separação, com acrilamida a 7,5\%. Em cada poço foram colocados $40 \mathrm{ug}$ de extrato proteico total diluído no tampão da amostra, conforme mencionado anteriormente. A corrida eletroforética foi realizada a 70 volts por 30 minutos, para separar as amostras no gel stacking (4\% de acrilamida) e a 100 volts por 1 hora, para o gel de separação (7,5\% de acrilamida).

O blotting foi realizado em membrana de nitrocelulose, previamente incubada no tampão de transferência (50 mL de tampão blotting $10 \mathrm{x}^{*}, 125 \mathrm{~mL}$ metanol e 450 $\mathrm{mL}$ de $\mathrm{H}_{2} \mathrm{O}$ destilada; *Tampão blotting 10x: $85,5 \mathrm{~g}$ de glicina, $18 \mathrm{~g}$ de Tris-Base e 480 $\mathrm{mL}$ de $\mathrm{H}_{2} \mathrm{O}$ destilada) em $200 \mathrm{~mA}$, por 2 horas em banho de gelo. Após o término do 
blotting a membrana foi lavada $1 x$ com TBS $1 \times$ por 5 minutos, em agitação; e 3x com TBS Tween $0,1 \%$ por 5 minutos.

Para bloquear as possíveis ligações não específicas, as membranas foram incubadas em solução de PBS $1 \mathrm{X}$ com 1\% de albumina por 1 hora, em temperatura ambiente, sob agitação. Os anticorpos primários utilizados foram para COX-1 (1:2000; COX-1 antibody (H-62), SC-7950; Santa Cruz Biotechnology ${ }^{\circledR}$,inc., CA EUA) e COX-2 (1:2000; COX-2 antibody (H-62), SC-7951; Santa Cruz Biotechnology ${ }^{\circledR}$,inc., CA - EUA), EP1 (1:100; EP1 Receptor Polyclonal; Cayman Chemical, Michigan - EUA), EP2 (1:100; EP2 Receptor Polyclonal; Cayman Chemical, Michigan - EUA), EP3 (1:100; EP3 Receptor Polyclonal; Cayman Chemical, Michigan - EUA), EP4 (1:100; EP4 Receptor Polyclonal; Cayman Chemical, Michigan - EUA) e $\beta$-Actina (1:200; Actin antibody (H-300), SC-10731; Santa Cruz Biotechnology ${ }^{\oplus}$,inc., CA- EUA). Todos foram incubados overnight, em temperatura ambiente e sob agitação. Em seguida, foram incubados com anticorpo secundário conjugado com peroxidase (1:1000 donkey anti-habbit lgG HRP; Santa Cruz Biotechnology ${ }^{\circledR}$,inc., CA- EUA). A visualização foi realizada por detecção quimioluminescente utilizando $E C L^{T M}$ Western Blotting Detection Reagents (GE Healthcare) no equipamento G:Box (Syngene, MD - EUA).

A análise das bandas foi realizada utilizando o programa Image $\mathrm{J}$.

\subsection{Ensaio de migração por transwell}

O ensaio de transwell foi realizado para analisar o efeito do tratamento do IBP e dos inibidores específicos SC-560 e NS-398 na migração da linhagem celular U251-MG.

Foram plaqueadas $2 \times 10^{4}$ células/poço no compartimento superior do transwell com meio de cultivo DMEM, suplementado com 10\% de SFB. O tratamento foi realizado após 12 horas do plaqueamento, período de aderência das células, e na concentração de $50 \mu \mathrm{M}$ de cada droga por 48 horas. A cada 24 horas foram trocados os meios de cultivo com os respectivos tratamentos.

Também foram plaqueadas $10^{5}$ células/poço em placas de 6 poços. $O$ tratamento foi realizado após 12 horas do plaqueamento, período de aderência das células. Foram tratadas com $50 \mu \mathrm{M}$ de cada droga por 36 horas em meio de cultivo DMEM, suplementado com $10 \%$ de SFB, sendo que após 24 horas de tratamento 
foram trocados os meios de cultivo com os respectivos tratamentos. Após as 36 horas de tratamento, as células foram tripsinizadas, contadas em Câmara de Neubauer, e foram plaqueadas $2 \times 10^{4}$ células/poço no compartimento superior do transwell com meio de cultivo DMEM, suplementado com $10 \%$ de SFB e com os respectivos tratamentos. As células foram incubadas no transwell por 12 horas, completando 48 horas de tratamento, mas apenas 12 horas de ensaio de migração.

O meio de cultivo foi descartado, as células foram lavadas três vezes com tampão fosfato salino (PBS) 1X, pH 7.2. As células da porção superior da membrana do transwell, células que não migraram, foram removidas com hastes flexíveis. As células foram coradas com cristal violeta $(0,05 \%$ de cristal violeta e $70 \%$ de etanol) por 30 minutos, lavadas com PBS $1 \mathrm{X}, \mathrm{pH}$ 7.2. As membranas contendo as células coradas que migraram tiveram as imagens capturadas aleatoriamente em 5 campos diferentes no microscópio NiKon Optipht-Il, equipado com câmera Coolsnap Pro (Media Cybernetics, Bethesda, MD - EUA).

\subsection{Análise do ciclo celular por FACS-PI (fluorescent activated cell sorting com iodeto de propídeo)}

Pela análise do ciclo celular através da marcação do DNA com o iodeto de propídeo foi possível identificar as fases do ciclo celular, e assim analisar os efeitos da inibição de proliferação e do aumento de morte celular após os tratamentos com os inibidores de COX.

Foram plaqueadas $5 \times 10^{4}$ células/poço em placas de 12 poços, em triplicatas para cada tratamento, e foram tratadas com $50 \mu \mathrm{M}$ de IBP, SC-560 e NS-398 e com $10 \mu \mathrm{M}$ de AH6809 e L161.982 por 48 horas. Foram utilizados como controles, amostras que não recebeu nenhum tratamento, amostras tratadas com etanol P.A., veículo do IBP, e amostras tratadas com DMSO, veículo dos inibidores específicos e dos antagonistas dos EPs 2 e 4. Os meios de cultivo contendo os respectivos tratamentos foram trocados a cada 24 horas até completar as 48 horas de tratamento.

Os meios de cultivo de cada amostra foram coletados em tubo de polipropileno de $15 \mathrm{~mL}$, as células foram lavadas com PBS $1 \mathrm{X}$, o qual também foi adicionado ao mesmo tubo contendo o meio coletado. Tripsinizou-se as células e foram adicionadas ao mesmo tubo contendo o meio coletado e o PBS da lavagem 
das células. Centrifugou-se à 1000 RPM por 5 minutos; foi descartado o sobrenadante, o precipitado de células foi ressuspendido delicadamente em $1 \mathrm{ml}$ de PBS $1 \mathrm{X}$ e novamente foi centrifugado a 1000RPM por 5 minutos. Descartou-se 0 sobrenadante, ressuspendeu-se o precipitado delicadamente em $2 \mathrm{~mL}$ de etanol $70 \%$ gelado (preparado em PBS 1X) e as amostras foram incubadas por no mínimo 24 horas a $4 \stackrel{\circ}{\circ}$.

Centrifugou-se a 1000 RPM por 5 minutos, ressuspendeu-se o pellet em $0,5 \mathrm{~mL}$ de solução de iodeto de propídeo $(20 \mathrm{ug} / \mathrm{mL}$ de RNAse, $0,1 \%$ de Triton X100, $20 \mathrm{ug} / \mathrm{mL}$ de iodeto de propídeo, em PBS $1 \mathrm{X}$ ), foi incubado a $37^{\circ} \mathrm{C}$ por 30 minutos. Centrifugou-se a 1000 RPM por 5 minutos, descartou-se o sobrenadante e ressuspendeu-se o pellet delicadamente em $1 \mathrm{~mL}$ de PBS $1 \mathrm{X}$.

Foram contados 10.000 eventos para cada amostra em FACScalibur (fluorescent activated cell sorting - Becton Dickison) e analisados por meio do software Cell Quest - FACScalibur (Becton Dickison) - gentilmente cedido pelo Prof. Dr. Rui Curi do Departamento de Fisiologia e Biofísica, ICB-USP.

\subsection{Análise estatística}

Todos os dados obtidos estão apresentados como média \pm erro padrão (SE). As análises foram realizadas utilizando o programa Graph Pad Instat e Graph Pad Prism, por ANOVA e Test-t para comparação das amostras. As diferenças foram consideradas significantes com $p<0,05$. 


\section{RESULTADOS}

\subsection{Curva de dose-resposta de lbuprofeno}

Observou-se que o efeito do tratamento com IBP, inibidor não seletivo de COX-1 e COX-2, após 24 e 48 horas seguiu um padrão inversamente proporcional entre as concentrações utilizadas e a proliferação celular. Após 24 horas de tratamento não foi observado nenhum valor significativo, tanto em relação aos controles quanto entre as concentrações $(p=0.2193)$. Enquanto que, após 48 horas de tratamento as concentrações de $50 \mu \mathrm{M}, 75 \mu \mathrm{M}$ e $100 \mu \mathrm{M}$ foram consideradas significantes ( $p<0.05$ nas duas primeiras e $p<0.01$ na última concentração). Os controles não apresentaram diferença significativa (Figura 3), $n=3$.

Figura 3 - Curva de dose-resposta do tratamento com IBP

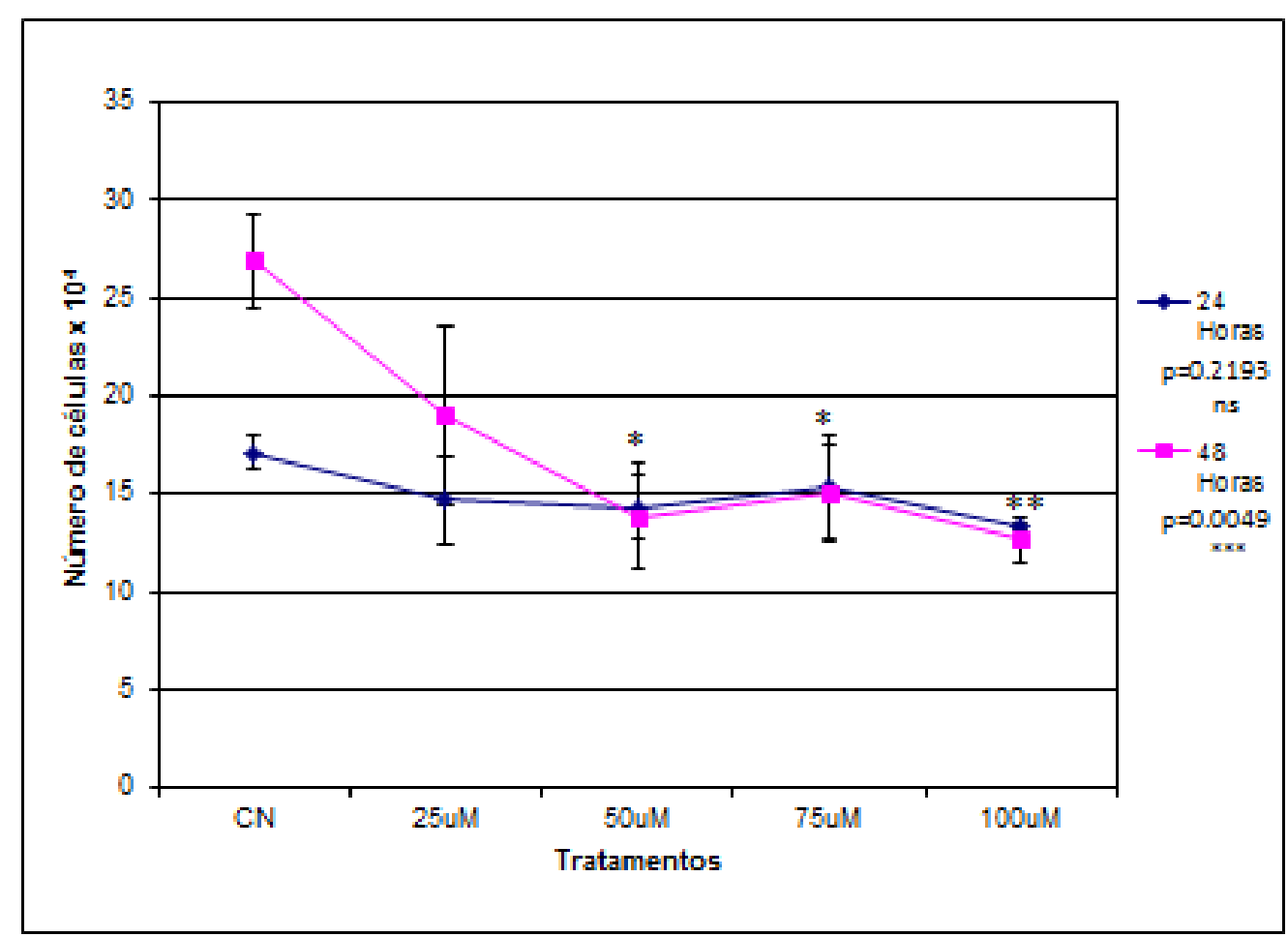

A concentração de $50 \mu \mathrm{M}$ foi a melhor concentração observada e escolhida para os ensaios; ela reduziu o número de células em $55,4 \%$ no período de 48 horas, sendo que não foi observado alteração na morfologia das células em relação aos controles, conforme observado nas concentrações maiores nesse mesmo período de tratamento (Figura 4). 
Figura 4 - Imagens da curva de dose-resposta do tratamento com IBP em 48 horas

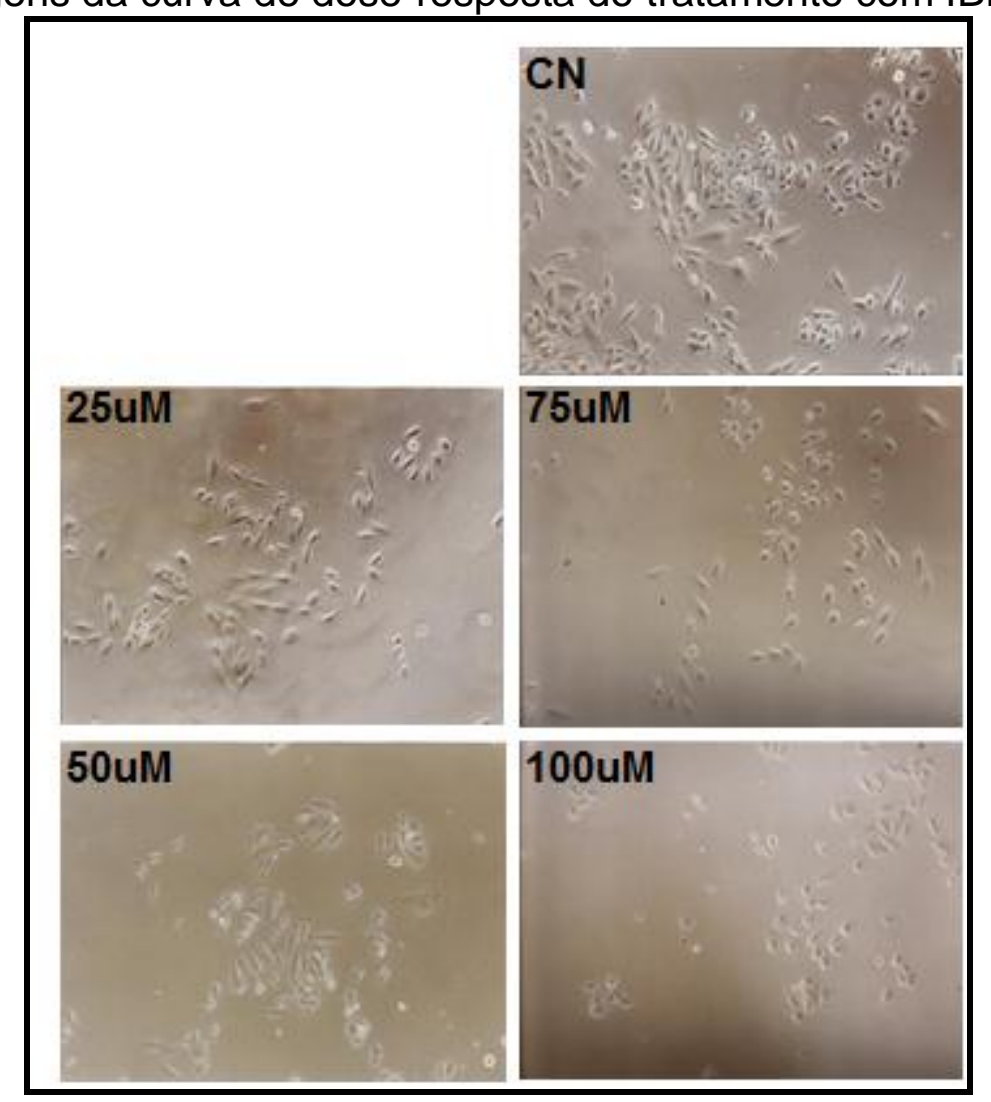

CN: controle sem nenhum tratamento. $25 \mu \mathrm{M}$ : tratamento por 48 horas com $25 \mu \mathrm{M}$ de IBP. $50 \mu \mathrm{M}$ : tratamento por 48 horas com $50 \mu \mathrm{M}$ de IBP. $\mathbf{7 5} \mu \mathrm{M}$ : tratamento por 48 horas com 75 $\mu \mathrm{M}$ de IBP.100 $\mu \mathrm{M}$ : tratamento por 48 horas com $100 \mu \mathrm{M}$ de SC-560.

\subsection{Curva de dose-resposta do tratamento com SC-560}

O tratamento com o inibidor seletivo para COX-1, SC-560, após 24 e 48 horas seguiu um padrão inversamente proporcional entre as concentrações utilizadas e o número de células contadas. A redução do número de células em todas as concentrações e em ambos os períodos de tratamentos, 24 e 48 horas, foi extremamente significativo $(p<0,001)$ em relação aos controles (Figura 5$)$. Os controles não apresentaram diferença significativa, $n=3$. 
Figura 5 - Curva de dose-resposta do tratamento com SC-560

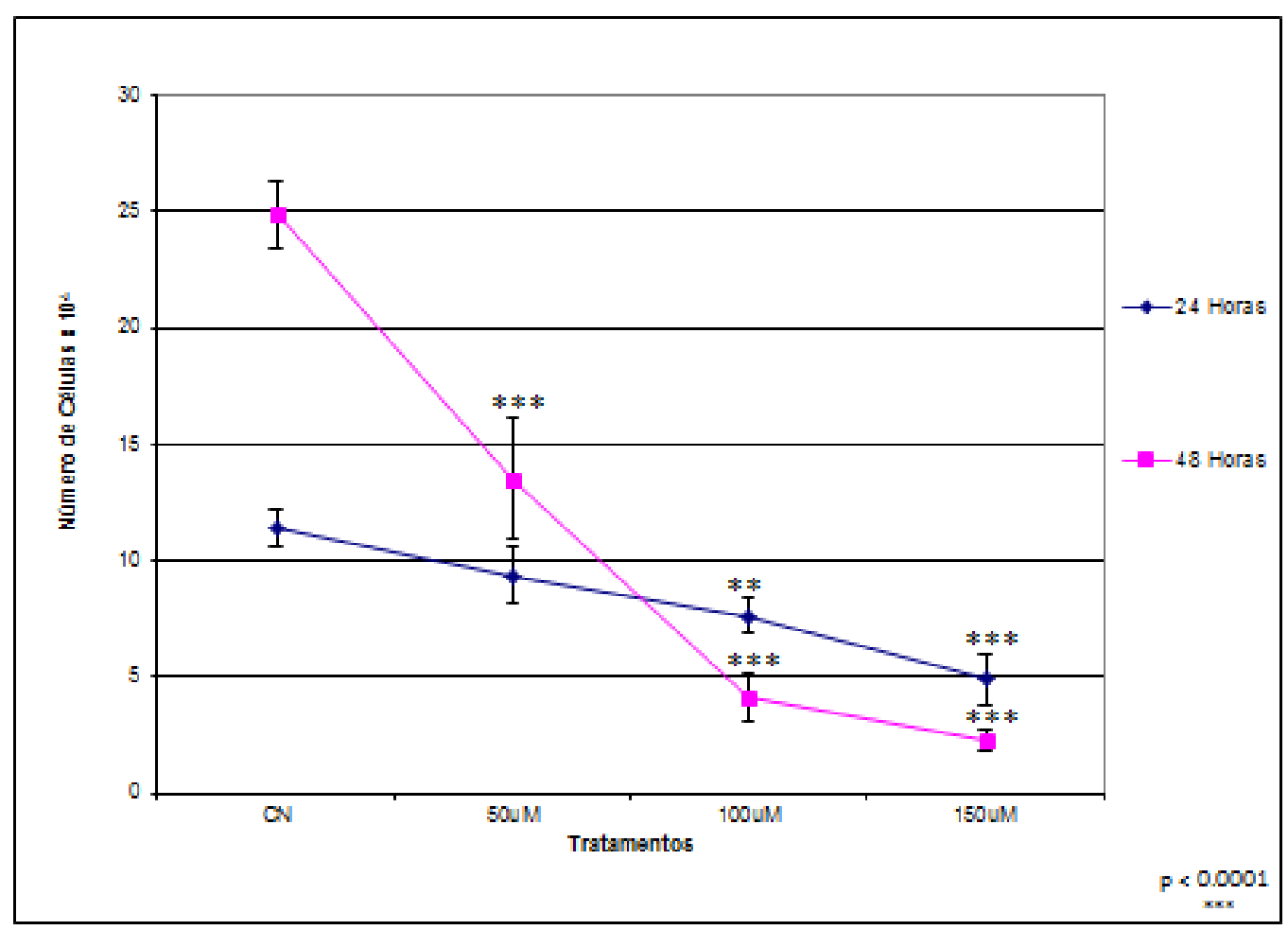

A concentração adotada para os experimentos foi a mesma concentração adotada para o tratamento com IBP, $50 \mu \mathrm{M}$. Assim, nos permitiu comparar o efeito de ambos sob a mesma concentração de tratamento, e ainda essa concentração reduziu significantemente o número de células, $45 \%$ em 48 horas, $p<0,001$ (Figura 5) sem agredir drasticamente a morfologia das mesmas (Figura 6). 
Figura 6 - Imagens da curva de dose-resposta do tratamento com SC-560 em 48 horas

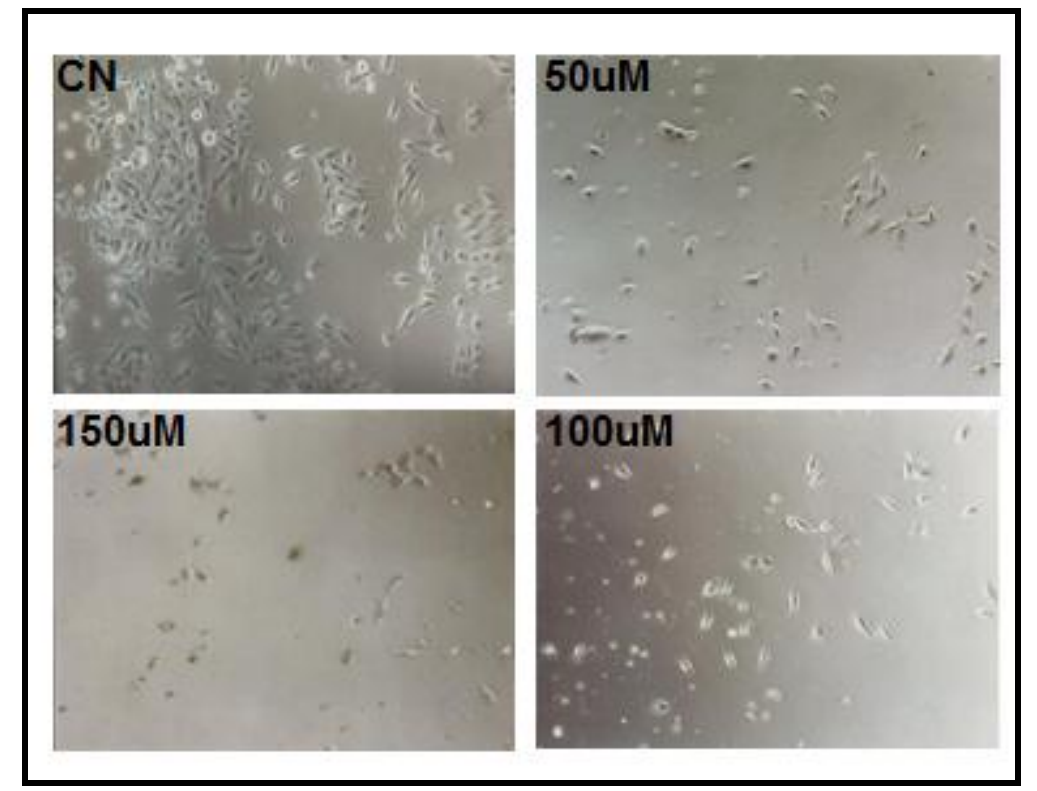

$\mathrm{CN}$ : controle sem nenhum tratamento. $\mathbf{5 0} \mu \mathrm{M}$ : tratamento por 48 horas com $50 \mu \mathrm{M}$ de SC560. $100 \mu \mathrm{M}$ : tratamento por 48 horas com $100 \mu \mathrm{M}$ de SC-560. $150 \mu \mathrm{M}$ : tratamento por 48 horas com $150 \mu \mathrm{M}$ de SC-560.

\subsection{Curva de dose-resposta do NS-398}

O tratamento com o inibidor seletivo para COX-2, NS-398, após 24 e 48 horas também seguiu o padrão inversamente proporcional entre as concentrações utilizadas e o número de células contadas. Nenhuma das concentrações tratadas em 24 horas foi significativa $(p=0,1641)$ em relação ao controle. No período de 48 horas, a concentração de $50 \mu \mathrm{M}$ também não apresentou significância em relação ao controle, enquanto que as concentrações de $100 \mu \mathrm{M}$ e $150 \mu \mathrm{M}$ foram consideradas significantes $(p<0,01$ e $p<0,001$, respectivamente) - Figura 7. Os controles não apresentaram diferença significativa, $\mathrm{n}=3 \mathrm{em}$ todos os controles e tratamentos. 
Figura 7 - Curva de dose-resposta do tratamento com NS-398

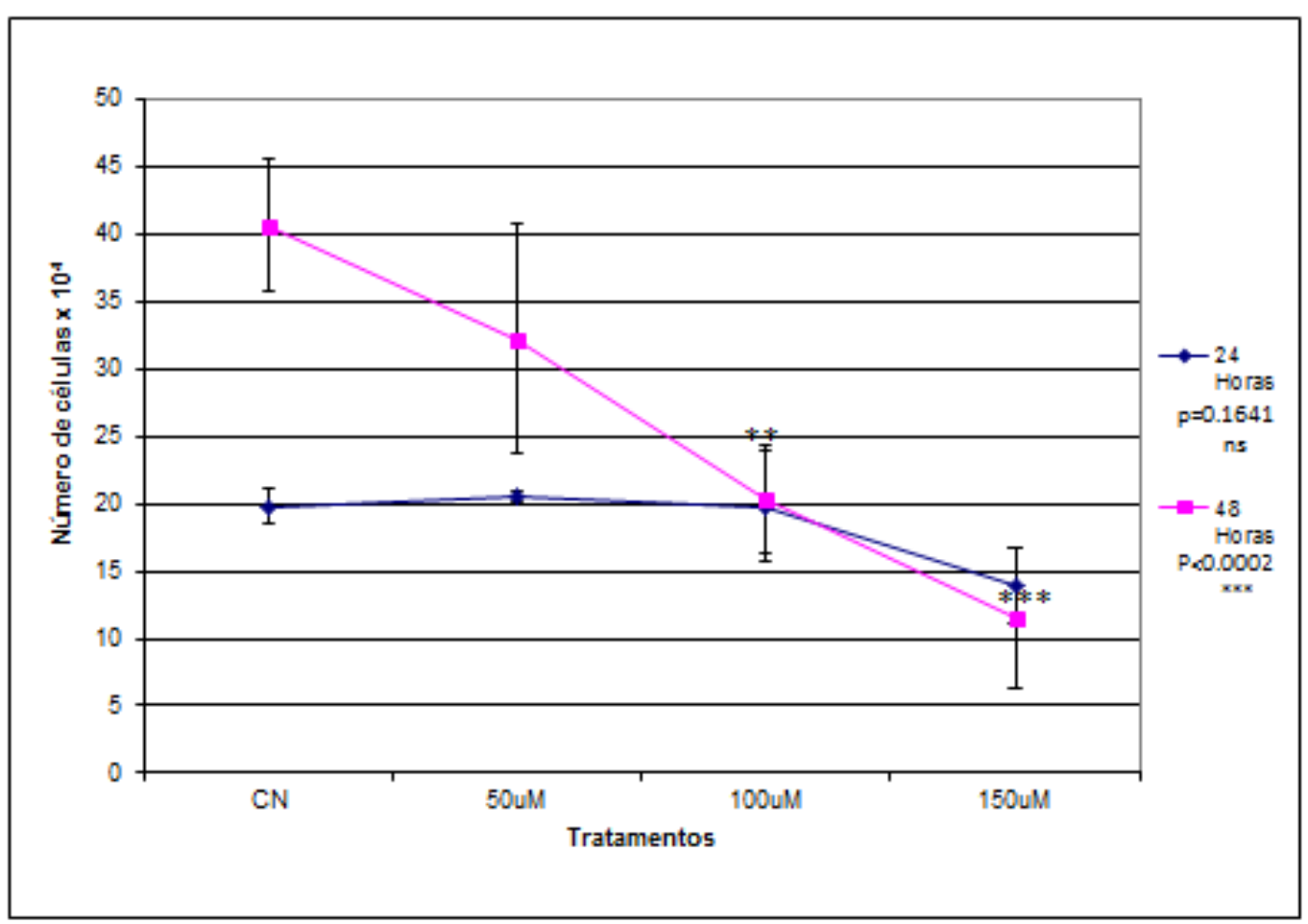

A concentração adotada para os experimentos foi a mesma concentração adotada para os tratamentos com IBP e SC-560, $50 \mu \mathrm{M}$. Apesar dessa concentração não ter apresentado redução significativa do número de células, 35\% em 48 horas de tratamento (Figura 7), nos permite comparar o efeito de todas as drogas sob a mesma concentração de tratamento. Observou-se que essa concentração não agrediu drasticamente a morfologia das células (Figura 8) em relação aos controles. 
Figura 8 - Imagens da curva de dose-resposta do NS-398 em 48 horas

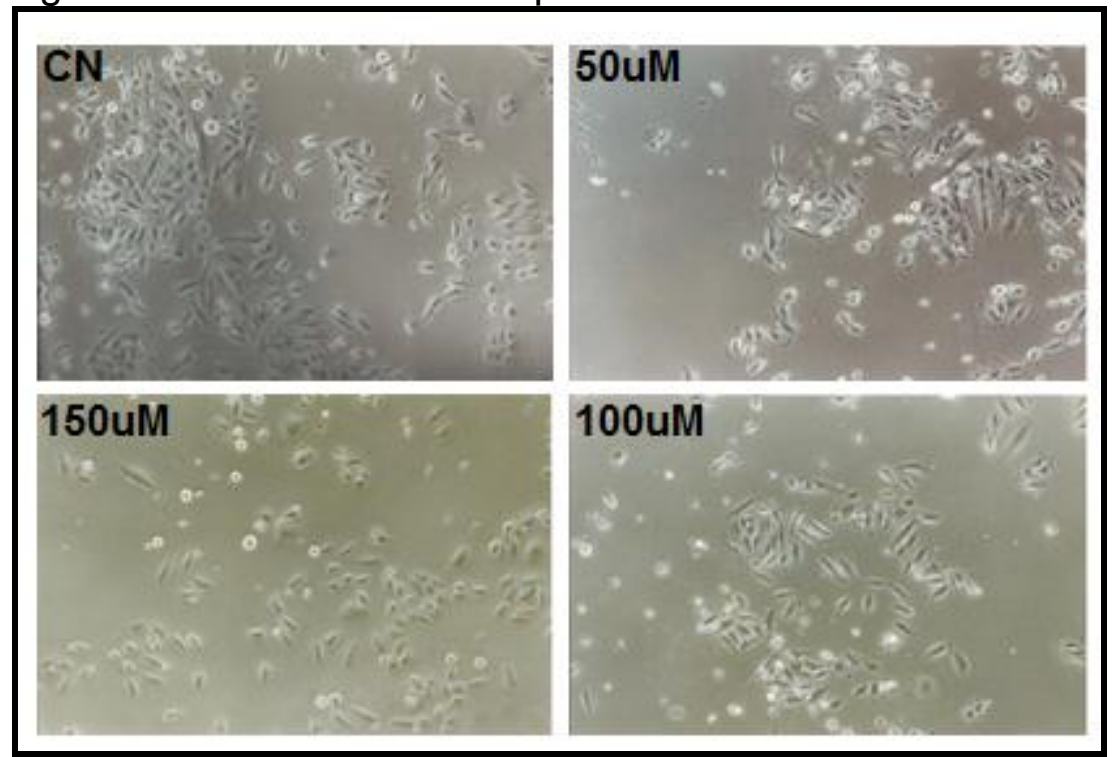

CN: controle sem nenhum tratamento. $50 \mu \mathrm{M}$ : tratamento por 48 horas com $50 \mu \mathrm{M}$ de NS398. $100 \mu \mathrm{M}$ : tratamento por 48 horas com $100 \mu \mathrm{M}$ de NS-398. $150 \mu \mathrm{M}$ : tratamento por 48 horas com $150 \mu \mathrm{M}$ de NS-398.

\subsection{Curva de Dose-Resposta do tratamento com AH6809}

O tratamento com $10 \mu \mathrm{M}$ do antagonista do EP2, AH6809, em 48 horas foi a única concentração que reduziu significativamente o número de células, $28,72 \%$, em relação aos controles (Figura 9). Dessa forma, essa concentração foi adotada para os ensaios com essa droga. Os controles não apresentaram diferença significativa, $\mathrm{n}=3$ em todos os controles e tratamentos. 
Figura 9 - Curva de dose-resposta do tratamento com AH6809

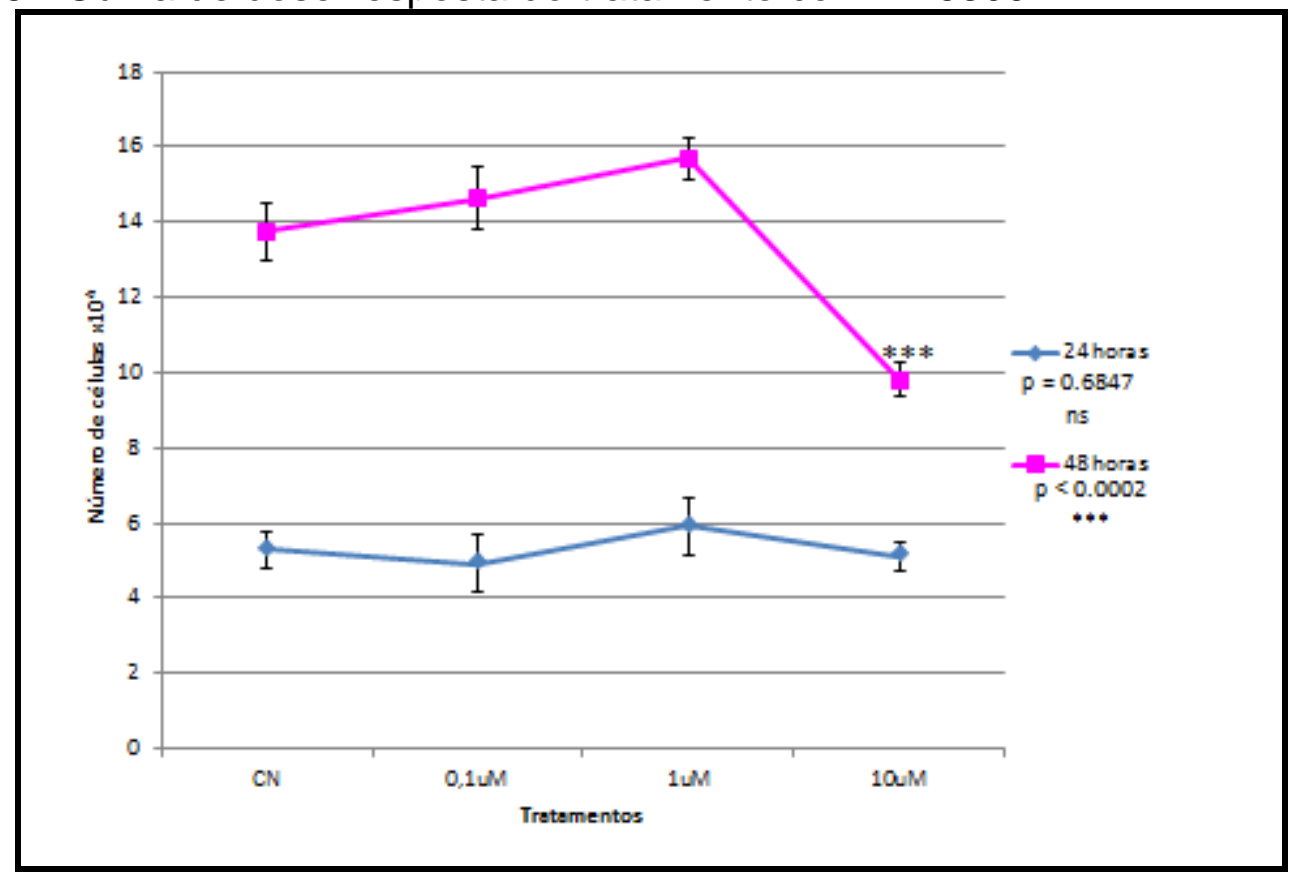

\subsection{Curva de dose-resposta do tratamento com L161.982}

O tratamento com $10 \mu \mathrm{M}$ do antagonista do EP4, L161.982, em 48 horas foi a única concentração que reduziu significativamente o número de células, 45,96\%, em relação aos controles (Figura 10). Portanto, essa concentração foi adotada para os ensaios com essa droga. Os controles não apresentaram diferença significativa, $n=3$ em todos os controles e tratamentos. 
Figura 10 - Curva de dose-resposta do tratamento com L161.982

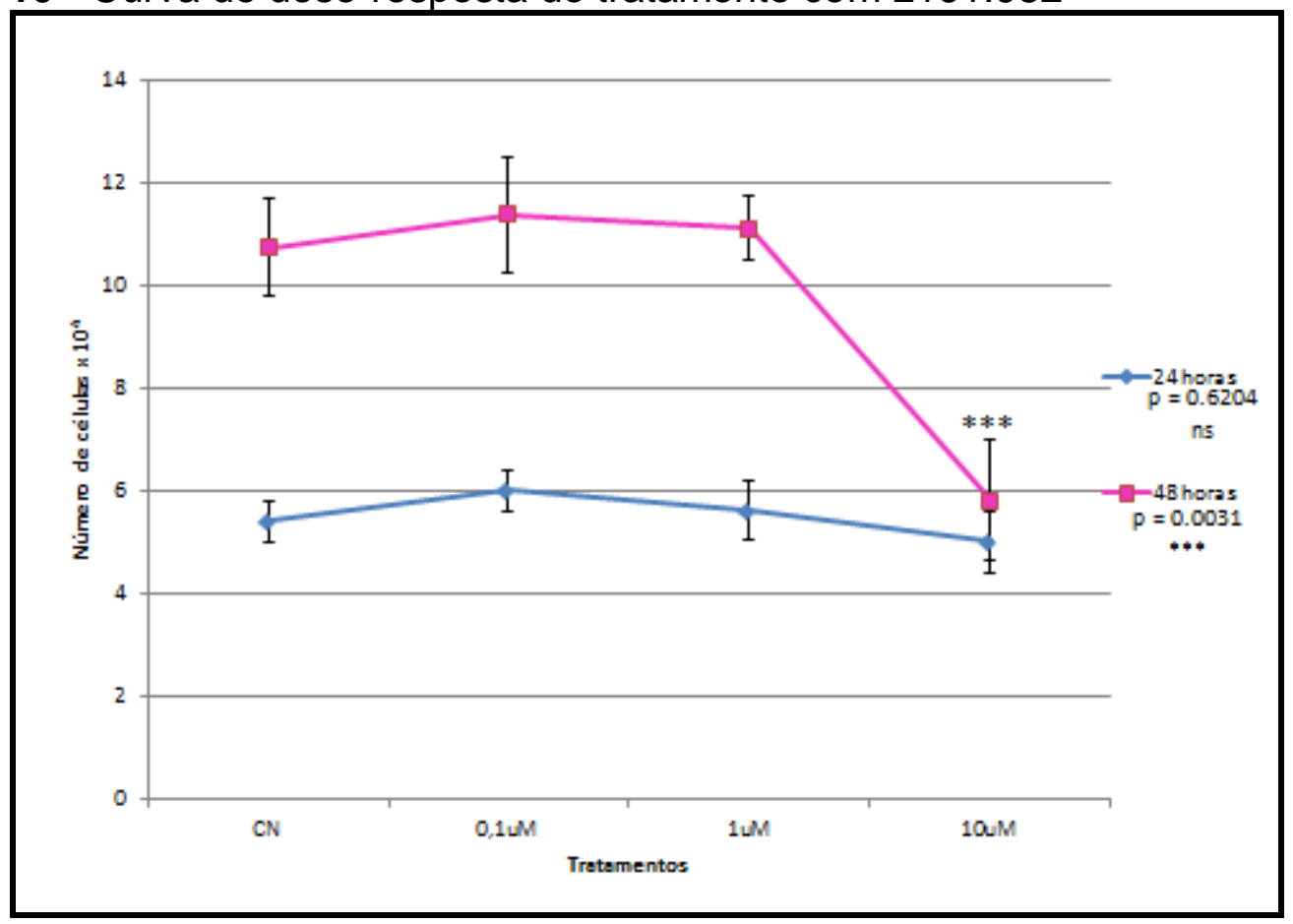

\subsection{Análise da expressão gênica através de RT-PCR semi-quantitativo}

4.6.1 Análise da expressão gênica de COX-1 e COX-2 na linhagem celular U251-MG

Foi observado que a linhagem celular U251-MG expressa tanto COX-1 (Figura 11) quanto COX-2 (Figura 12). Houve aumento significativo de $129 \%$ da expressão gênica de COX-1 no tratamento com IBP em relação ao controle $(\mathrm{p}<$ 0.001). Não obstante, também foi observada diminuição significativa de 50,8\% na expressão gênica de COX-1 no tratamento com SC-560 ( $p<0.001)$; e diminuição não significativa de $30 \%$ da expressão deste gene no tratamento com NS-398. Não houve diferença significativa de expressão entre os controles. 
Figura 11 - Expressão Gênica de COX-1

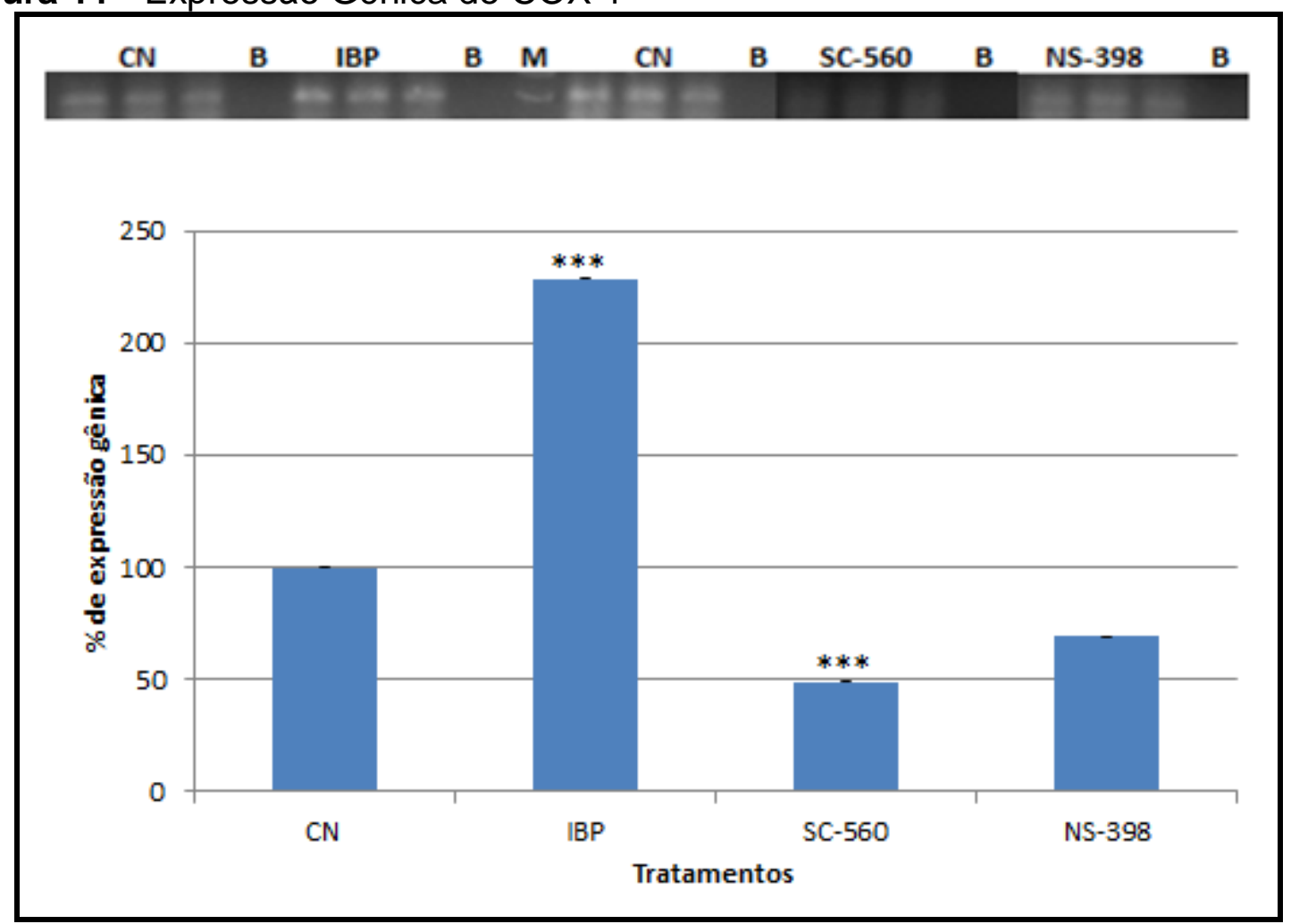

CN: controle. IBP: amostras tratadas com IBP. NS-398: amostras tratadas com NS-398. SC560: amostras tratadas com SC-560. B: branco de cada reação corresponde ao controle da reação. M: marcador de peso molecular 100bp DNA Ladder (Invitrogen - CA, EUA).

Não houve diferença significativa na expressão gênica de COX-2 (Figura 12) e do gene constitutivo GAPDH (Figura 13) entre nenhum dos tratamentos (IBP, SC560 e NS-398) e controles. 
Figura 12 - Expressão Gênica de COX-2

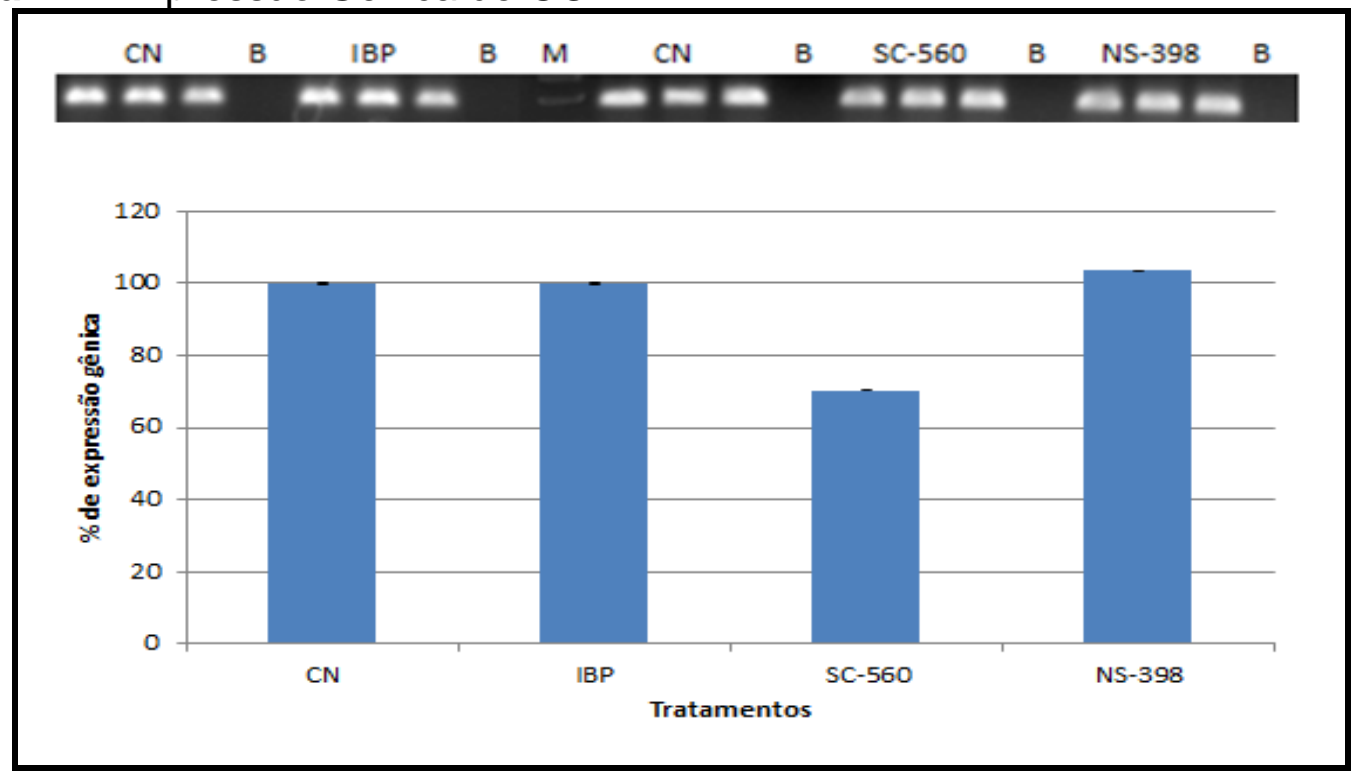

CN: controle. IBP: amostras tratadas com IBP. NS-398: amostras tratadas com NS-398. SC560: amostras tratadas com SC-560. B: branco de cada reação corresponde ao controle da reação. M: marcador de peso molecular 100bp DNA Ladder (Invitrogen - CA, EUA).

Figura 13 - Expressão Gênica de GAPDH

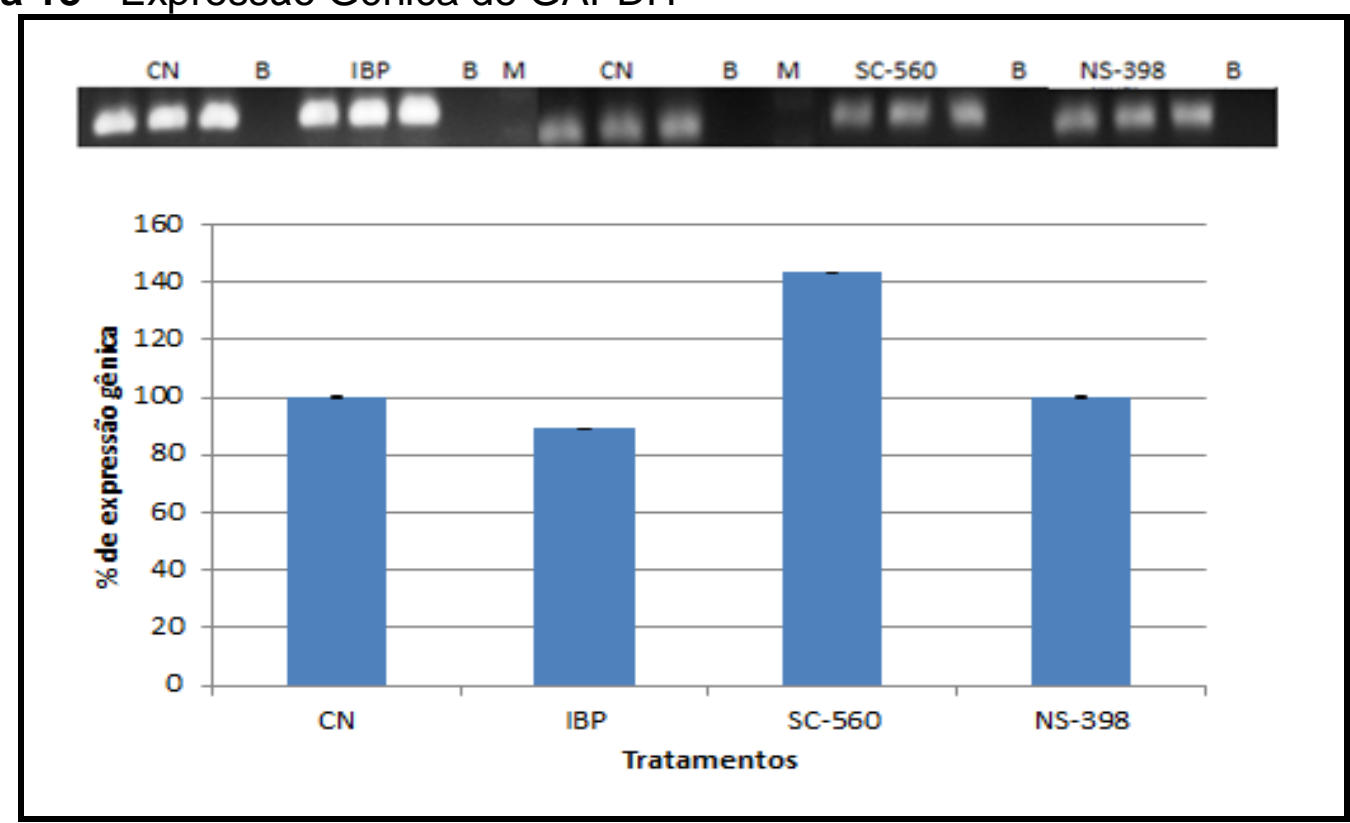

CN: controle. IBP: amostras tratadas com IBP. NS-398: amostras tratadas com NS-398. SC560: amostras tratadas com SC-560. B: branco de cada reação corresponde ao controle da reação. M: marcador de peso molecular 100bp DNA Ladder (Invitrogen - CA, EUA). 
4.6.2 Análise da expressão gênica de EP1, EP2, EP3 e EP4 na linhagem celular U251-MG

A linhagem U251-MG expressa todos os receptores de PGE 2 EP1, EP2, EP3 e EP4 (Figura 14).

Figura 14 - Expressão gênica dos receptores EPs na linhagem U251-MG

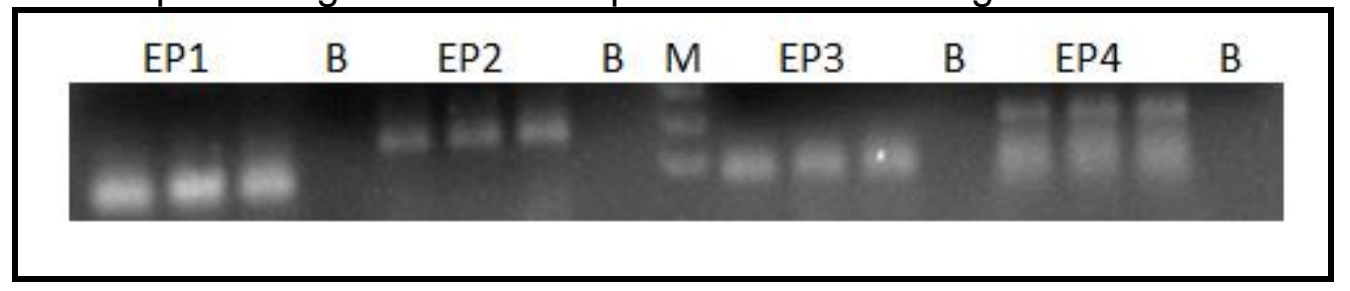

EP1: expressão gênica do receptor EP1, B: branco de cada reação corresponde ao controle da reação. EP2: expressão gênica do receptor EP2. M: marcador de peso molecular 100bp DNA Ladder (Invitrogen - CA, EUA). EP3: expressão gênica do receptor EP3. EP4: expressão gênica do receptor EP4.

Foi realizada a análise de expressão gênica do gene constitutivo GAPDH, o qual esteve expresso tanto no controle, quanto nas amostras tratadas com os antagonistas de EP2 e EP4, AH6809 e L161.982, respectivamente (Figura 15).

Figura 15 - Expressão Gênica de GAPDH

\begin{tabular}{|c|cccccc|}
\hline CN & B & AH6809 & B & M & L161.982 & M \\
\hline & & & & & &
\end{tabular}

CN: expressão gênica de GAPDH no controle normal, sem nenhum tratamento. B: branco de cada reação corresponde ao controle da reação. AH6809: expressão gênica de GAPDH na amostra tratada com AH6809. M: marcador de peso molecular 100bp DNA Ladder (Invitrogen - CA, EUA). L161.982: expressão gênica de GAPDH na amostra tratada com L161.982.

$\mathrm{Na}$ análise da expressão gênica do receptor EP2 foi observado aumento significativo de $123 \%$ da expressão deste gene $(p<0.05)$ no tratamento com 0 antagonista de EP2, AH6809, em relação ao controle. Contudo, não foi observada diferença significativa na expressão deste gene entre nenhum dos demais tratamentos em relação aos seus respectivos controles, apesar de ter sido observado aumento de $58 \%$ da expressão deste gene para o tratamento com L161.982 (antagonista de EP4), pequeno aumento de 5\% com IBP e NS-398 (inibidor não específico de COX1 e COX-2; e inibidor específico de COX-2, 
respectivamente) e diminuição de 10\% com SC-560 (inibidor específico de COX-1) Figura 16.

Figura 16 - Expressão Gênica de EP2

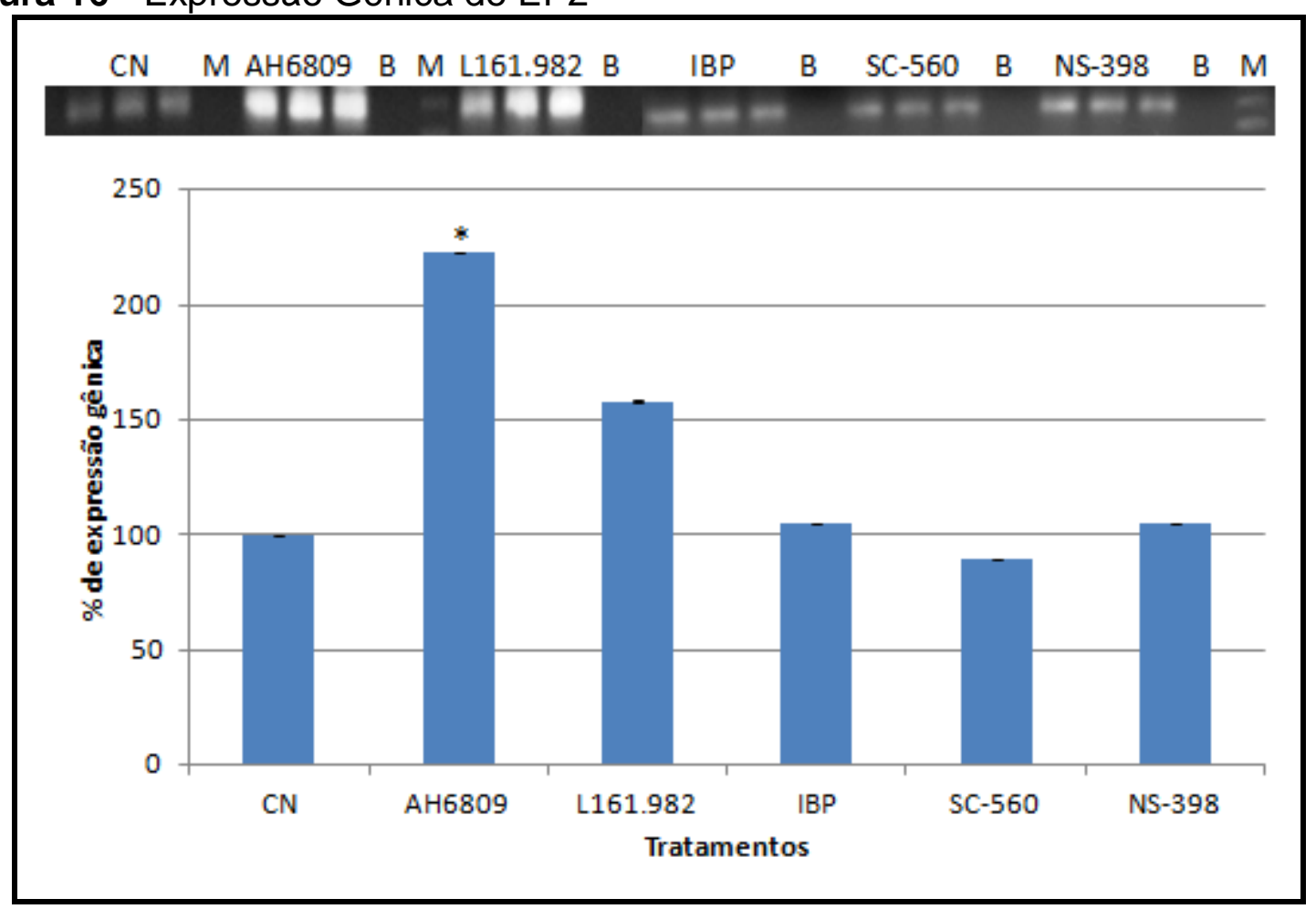

CN: controle. AH6809: amostras tratadas com AH6809, antagonista do EP2. L161.982: amostras tratadas com L161.982, antagonista do EP4. IBP: amostras tratadas com IBP. SC560: amostras tratadas com SC-560. NS-398: amostras tratadas com NS-398. B: branco de cada reação corresponde ao controle da reação. M: marcador de peso molecular $100 \mathrm{bp}$ DNA Ladder (Invitrogen - CA, EUA).

A expressão gênica do receptor EP4 apresentou diferença significativa entre os controles (veículo das drogas: DMSO e etanol), portanto os antagonistas de EP2 (AH6809) e de EP4 (L161.982); e os inibidores específicos de COX-1 (SC-560) e de COX-2 (NS-398) foram comparados com o controle do veículo destas drogas (DMSO). Enquanto que o tratamento com IBP foi comparado com controle do veículo desta droga (etanol). Ambos foram normalizados para 100\% e chamados de CN.

Foi observado aumento significativo de $85,5 \%$ da expressão gênica de EP4 entre o tratamento com IBP e seu respectivo controle $(p<0.05)$. Para os demais tratamentos, não foi observada diferença significativa da expressão deste gene em relação aos respectivos controles. Apesar de ter sido observado aumento da expressão de 63\%, 37\% e 18\% nos tratamentos com AH6809 (antagonista de EP2), 
L161.982 (antagonista de EP4) e NS-398, respectivamente. Já o tratamento com SC-560, apresentou diminuição não significativa da expressão de 22\% (Figura 17).

Figura 17 - Expressão gênica de EP4

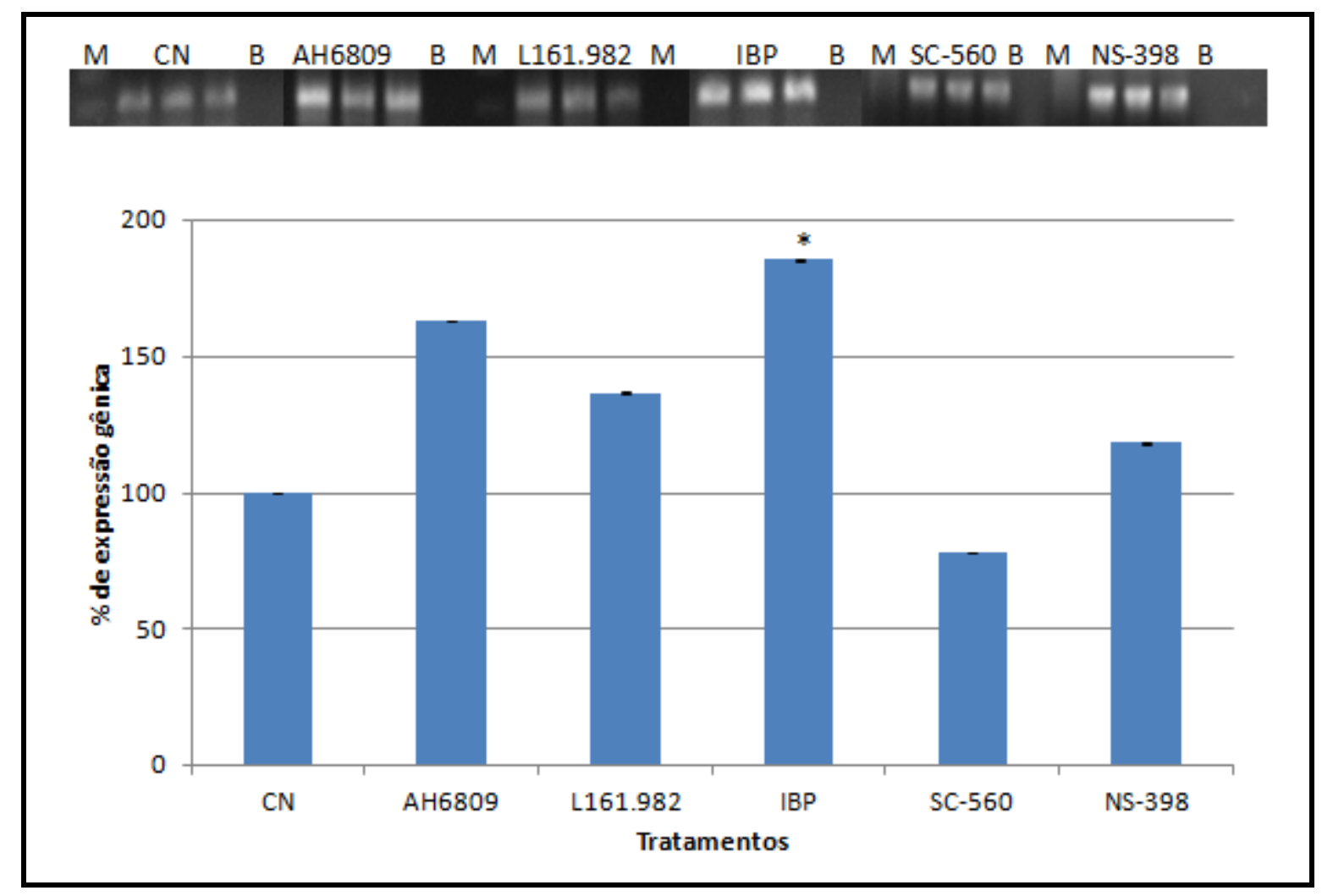

CN: controle. AH6809: amostras tratadas com AH6809, antagonista do EP2. L161.982: amostras tratadas com L161.982, antagonista do EP4. IBP: amostras tratadas com IBP. SC560: amostras tratadas com SC-560. NS-398: amostras tratadas com NS-398. B: branco de cada reação corresponde ao controle da reação. M: marcador de peso molecular 100bp DNA Ladder (Invitrogen - CA, EUA).

\subsection{Western blot}

\subsubsection{Expressão proteica de COX-1 e COX-2}

Ambas as proteínas, tanto COX-1 quanto COX-2, são expressas na linhagem celular U251-MG. Não houve diferença significativa na expressão proteica entre o controle e o tratamento com IBP, apesar de ter sido observado aumento de 16,7\% na expressão de COX-1 e de 6,8\% na expressão de COX-2 neste tratamento (Figura 18). 
Figura 18 - Expressão proteica de COX-1 e COX-2 no tratamento com IBP

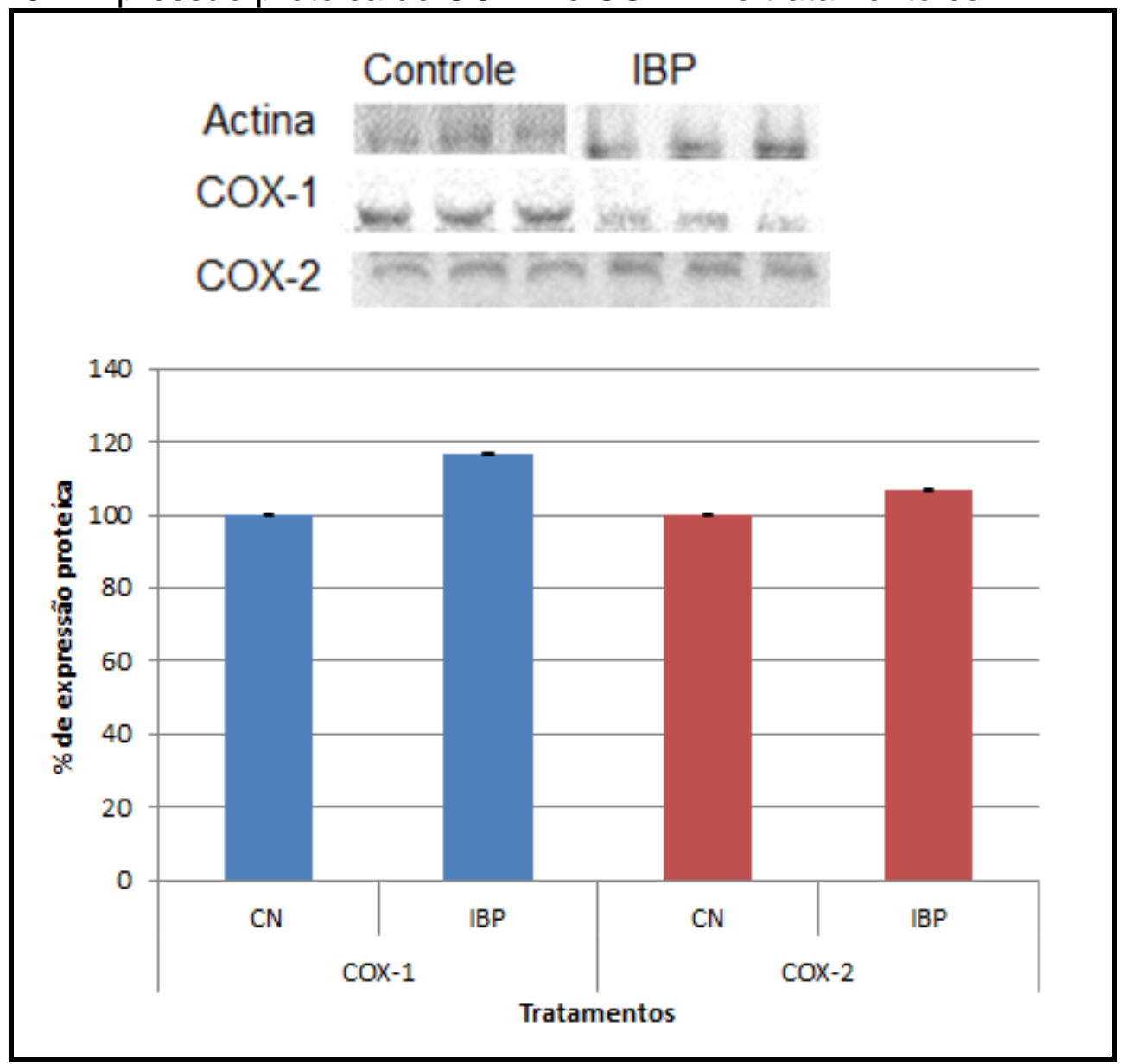

Em relação ao tratamento com o inibidor específico de COX-1, SC-560, também não foi observada diferença significativa na expressão proteica entre o controle e o tratado, apesar de ter sido observado aumento de $24,4 \%$ na expressão de COX-2 (Figura 19). 
Figura 19 - Expressão proteica de COX-1 e COX-2 no tratamento com SC-560

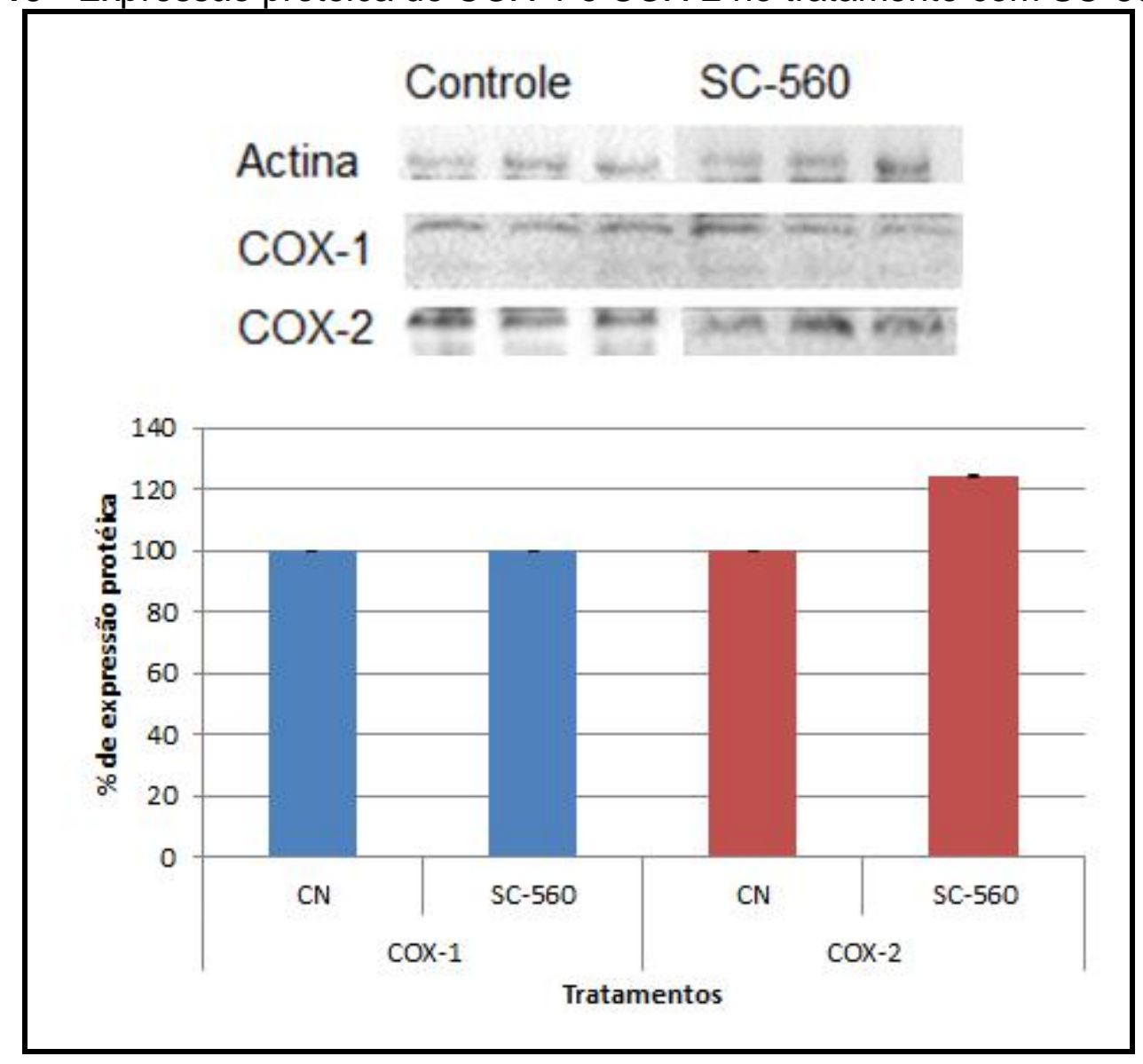

Em relação ao tratamento com o inibidor específico de COX-2, NS-398, também não foi observada diferença significativa na expressão proteica entre o controle e o tratado, apesar de ter sido observado aumento de 30,5\% na expressão de COX-2 (Figura 20). 
Figura 20 - Expressão proteica de COX-1 e COX-2 no tratamento com NS-398

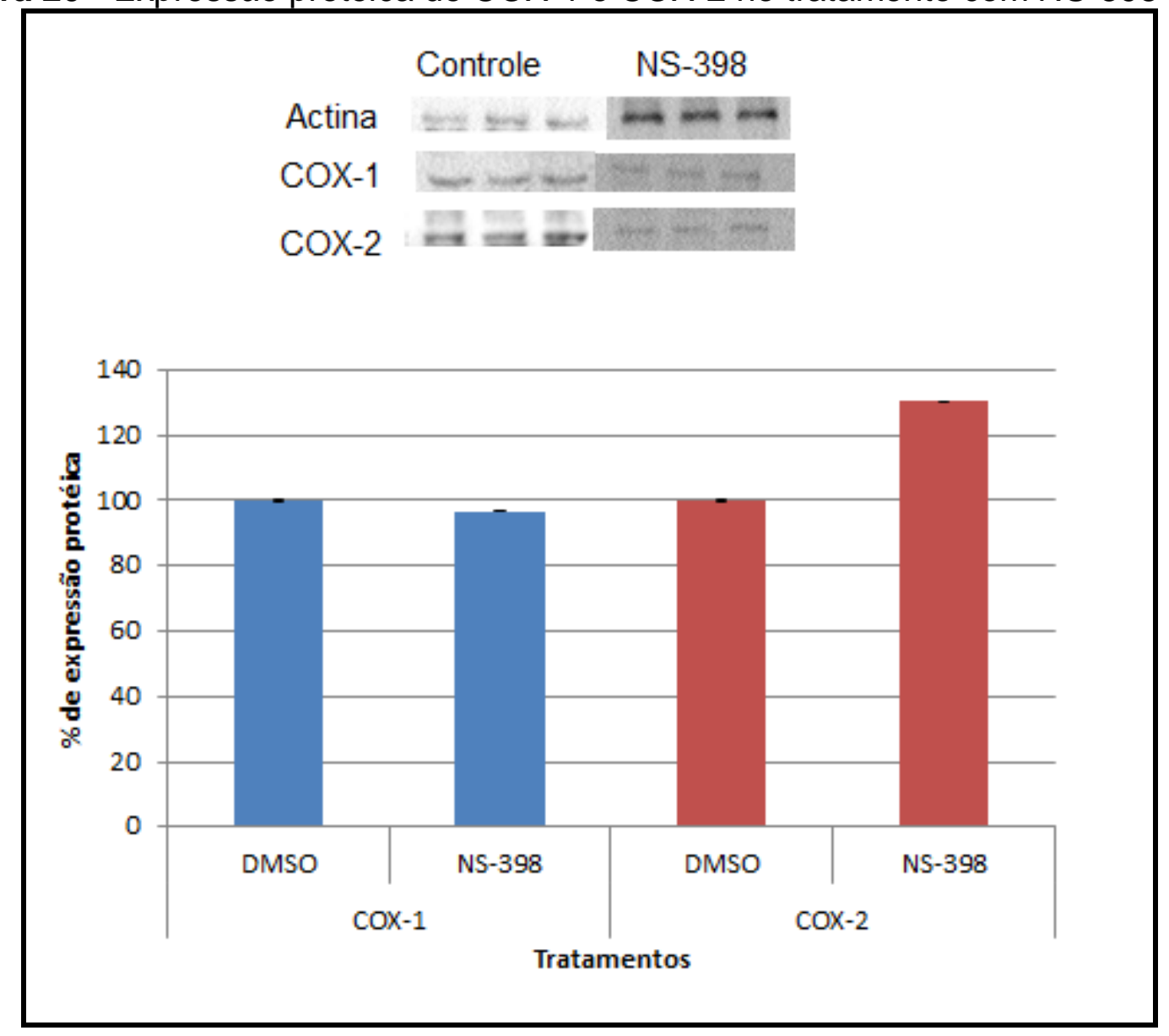

4.7.2 Expressão proteica de EP1, EP2, EP3 e EP4

A linhagem celular U251-MG apresentou expressão proteica para EP1, EP2, EP3 e EP4 (Figura 21).

Figura 21 - Expressão proteica dos EPs na linhagem celular U251-MG U251-MG

Actina

EP1

EP2

EP3

EP4

\subsubsection{Expressão proteica de EP2}

$\mathrm{O}$ tratamento com o antagonista de EP2, AH6809 apresentou ligeiro aumento não significativo de $8 \%$ na expressão deste gene. Porém os tratamentos com o inibidor específico de COX-1, SC-560; inibidor específico de COX-2, NS-398; e com 
inibidor não seletivo de COX-1 e COX-2, IBP; não apresentaram expressão para este receptor (Figura 22).

Figura 22 - Expressão de EP2 no tratamento com AH6809, SC-560, NS-398 e IBP

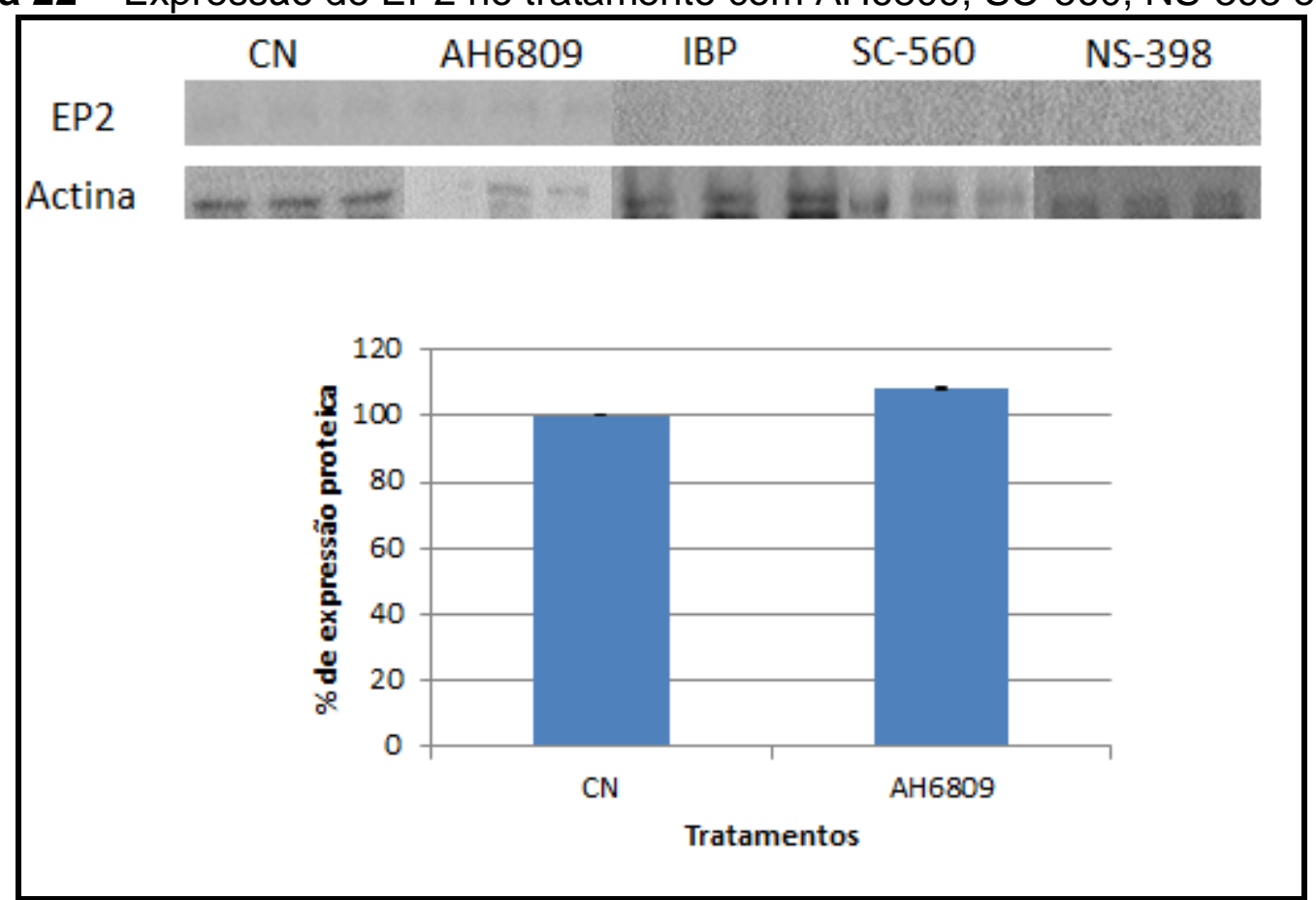

\subsubsection{Expressão proteica de EP4}

A expressão proteica para o receptor EP4 apresentou aumento significativo de $100 \%(p<0,5)$ no tratamento com o antagonista deste receptor, L161.982. Entretanto, não foi observada diferença significativa da expressão deste gene para os tratamentos com o inibidor específico de COX-1, SC-560; e com o IBP, inibidor não seletivo de COX-1 e COX-2, em relação ao controle. Apesar de ter sido observada redução da expressão gênica de $42 \%$ no tratamento com IBP. Contudo, não foi observada expressão deste receptor para o tratamento com NS-398, inibidor específico de COX-2 (Figura 23). 
Figura 23 - Expressão de EP4 no tratamento com L161.982, SC-560, NS-398 e IBP

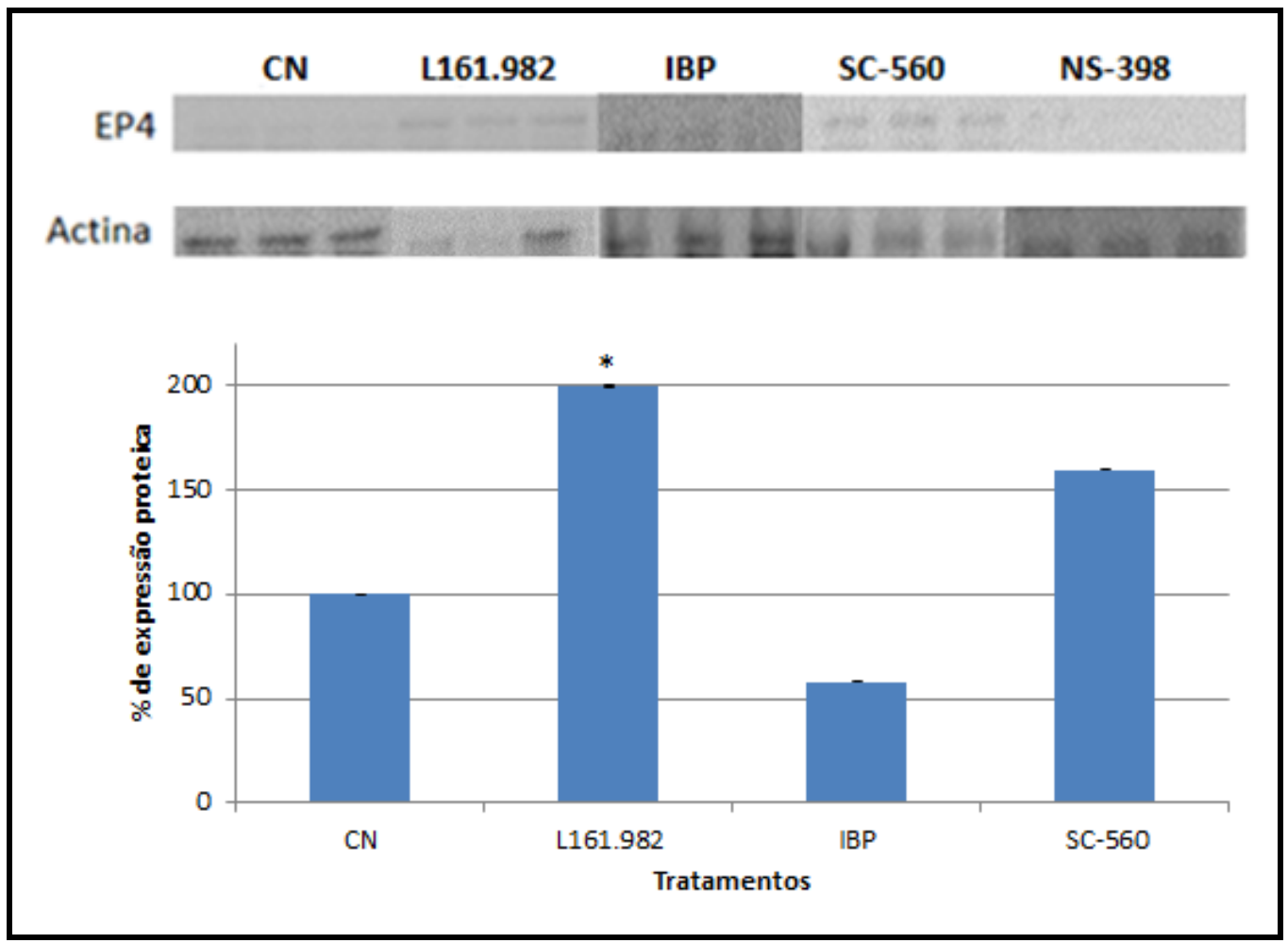

\subsection{Ensaio de migração}

O tratamento por 48 horas com $50 \mu \mathrm{M}$ de IBP, inibidor não seletivo de COX-1 e 2, inibiu significativamente a migração celular em $48 \%$ em relação ao controle, $\mathrm{p}<0,05$ (Figura 24 e 25) - no ensaio de 48 horas em transwell. A mesma concentração do inibidor específico para COX-1, SC-560, inibiu a migração celular em $42,5 \%$, em relação ao controle - também considerado significante $p<0,05$ (Figuras 24 e 25). Enquanto que a mesma concentração do inibidor específico para COX-2, NS-398, inibiu a migração celular em $24,84 \%$ em relação ao controle e não foi considerado significativo (Figuras 24 e 25).

Todos os controles, tanto os que receberam os veículos dos tratamentos, etanol para IBP e DMSO para inibidores específicos, quanto os controles que não receberam nenhum tratamento não apresentam diferença significativa, foram somados e a média foi denominada de $\mathrm{CN}$. 
Figura 24 - Gráfico da migração celular após o tratamento com IBP, SC560 e NS398

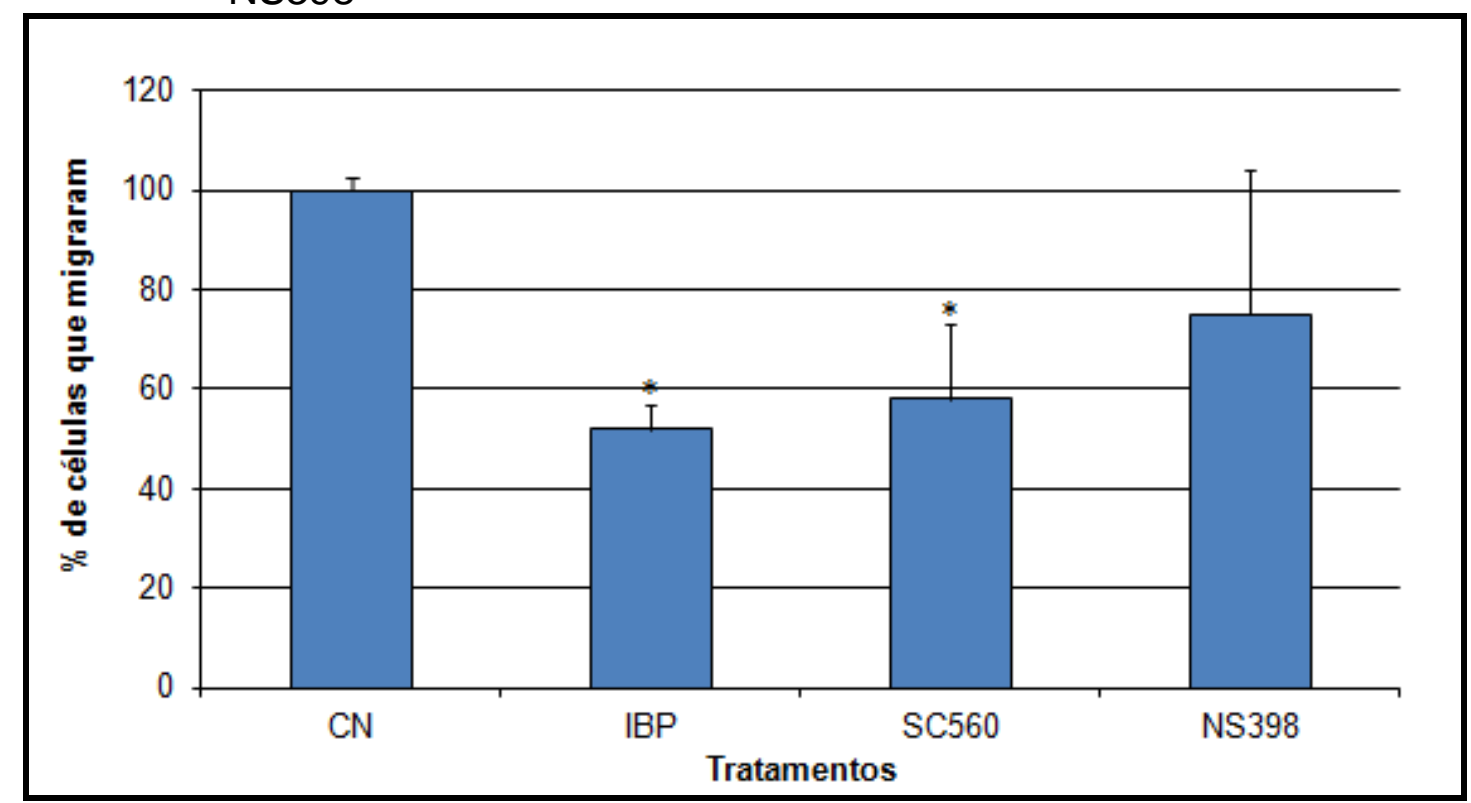

Figura 25 - Imagens da migração celular após o tratamento com IBP, SC-560 e NS398

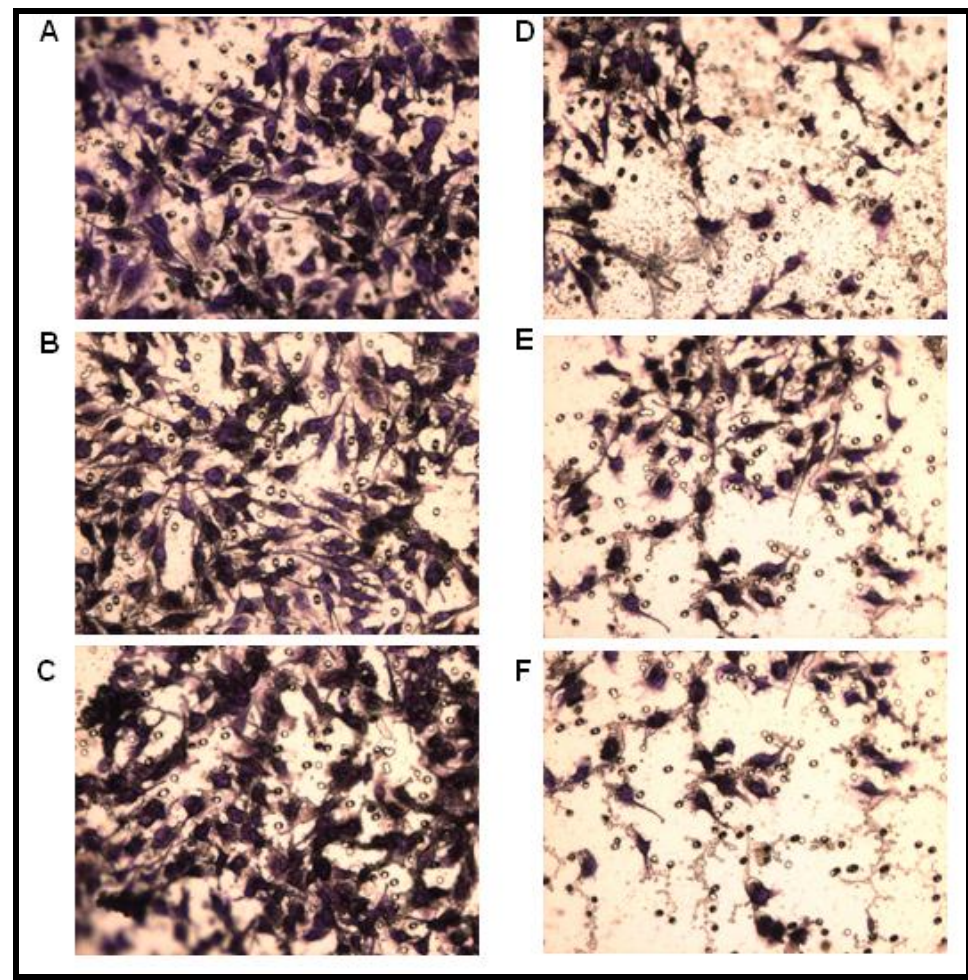

A. Controle que não recebeu tratamento; B. controle tratado com etanol P.A., veículo do IBP; C. controle tratado com DMSO, veículo do tratamento com NS-398 e SC-560; D. tratamento com $50 \mu \mathrm{M}$ de IBP; E. tratamento com $50 \mu \mathrm{M}$ de NS-398 e F. tratamento com 50 $\mu \mathrm{M}$ de SC-560.

Já no ensaio de transwell por 12 horas, foi observado que o tratamento com SC-560 foi o que apresentou maior inibição da migração, 71,05\%; em seguida o tratamento com IBP inibiu a migração em 61\%; e o tratamento com NS-398 foi o que 
menos inibiu a migração, 59,5\% (Figura 26 e 27). Todos os tratamentos foram realizados com $50 \mu \mathrm{M}$ de cada droga por 48 horas e todos foram considerados significativos. Na tabela abaixo (Tabela 2) segue a comparação entre o transwell por 48 horas e o transwell por 12 horas.

Tabela 2 - Porcentagens de inibição da migração por Transwell Tratamentos Transwell por 48 horas Transwell por 12 horas

$\begin{array}{ccc}\text { IBP } & 48 \%( \pm 4,9) & 61 \%( \pm 3,7) \\ \text { SC-560 } & 42.5 \%( \pm 15,3) & 71 \%( \pm 3,9) \\ \text { NS-398 } & 24,8 \%( \pm 28,9) & 59,5 \%( \pm 8,8)\end{array}$

Figura 26 - Gráfico da migração celular pelo período de 12 horas

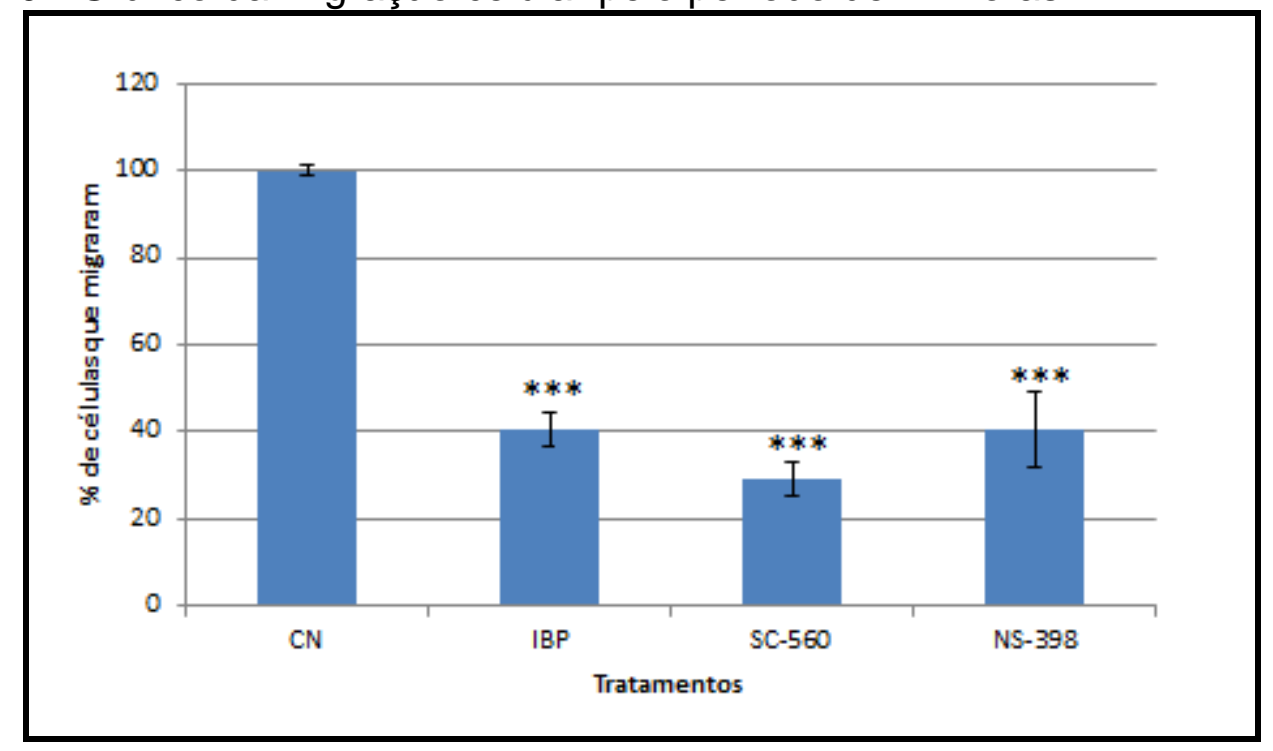


Figura 27 - Imagens da migração celular pelo período de 12 horas

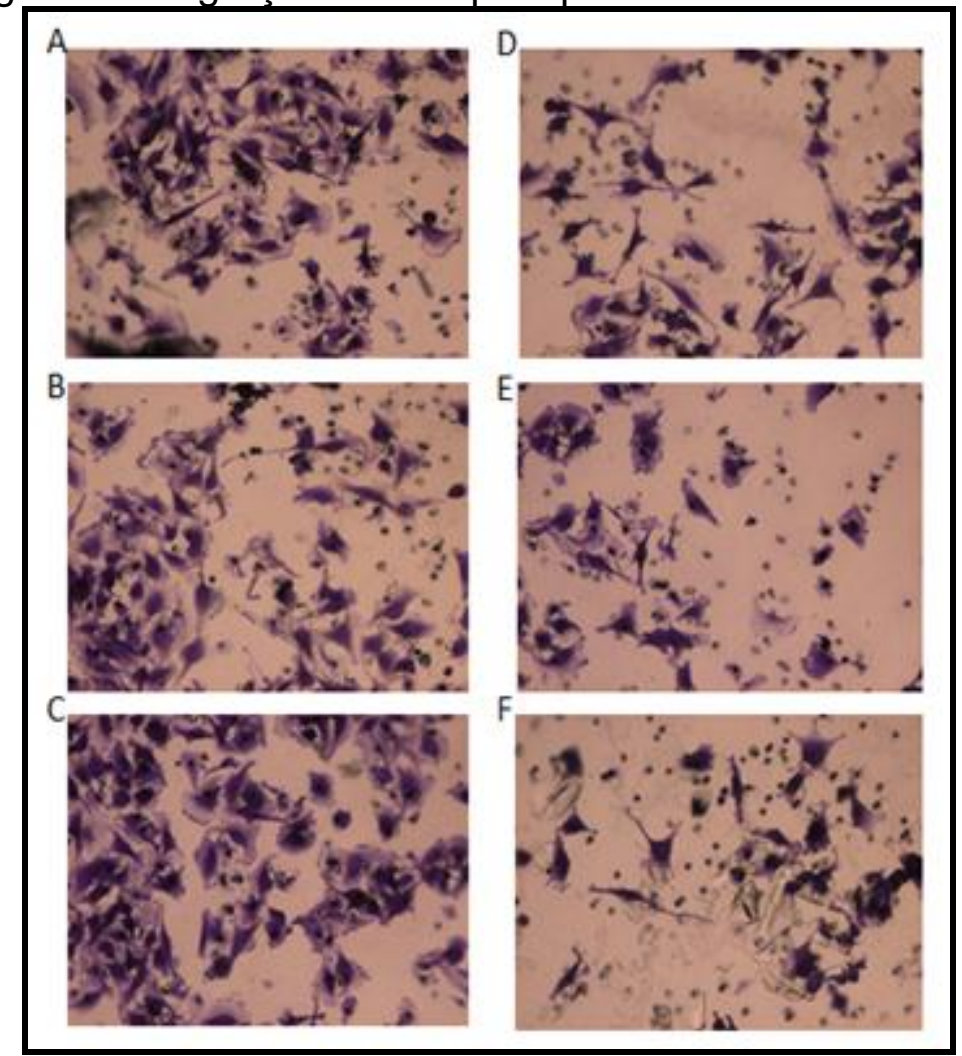

A. Controle que não recebeu tratamento; B. controle tratado com etanol P.A., veículo do IBP; C. controle tratado com DMSO, veículo do tratamento com NS-398 e SC-560; D. tratamento com $50 \mu \mathrm{M}$ de IBP; E. tratamento com $50 \mu \mathrm{M}$ de NS-398 e F. tratamento com 50 $\mu \mathrm{M}$ de SC-560.

\subsection{Ciclo celular}

\subsubsection{Análise do ciclo celular para os tratamentos com IBP, SC-560 e NS-398}

Os resultados das análises do ciclo celular do tratamento com IBP, SC-560 e NS-398 encontram-se na Figura 28 e na Tabela 3. A análise do ciclo celular apresentou diferença significativa na fase Sub-G1, indicando que os tratamentos tanto com IBP quanto com SC-560 e NS-398 resultaram em aumento de morte celular de 31\%,64\% e 49\%, respectivamente e em relação aos controles (Figura 29). Não obstante, também foi observada diferença significativa na fase $S$, indicando inibição da proliferação de 59,65\% no tratamento com IBP, 54,65\% com SC-560 e $58,02 \%$ com NS-398 em relação aos controles (Figura 29). 
Figura 28 - Gráficos de análise do ciclo celular do tratamento com IBP, SC-560 e NS-398

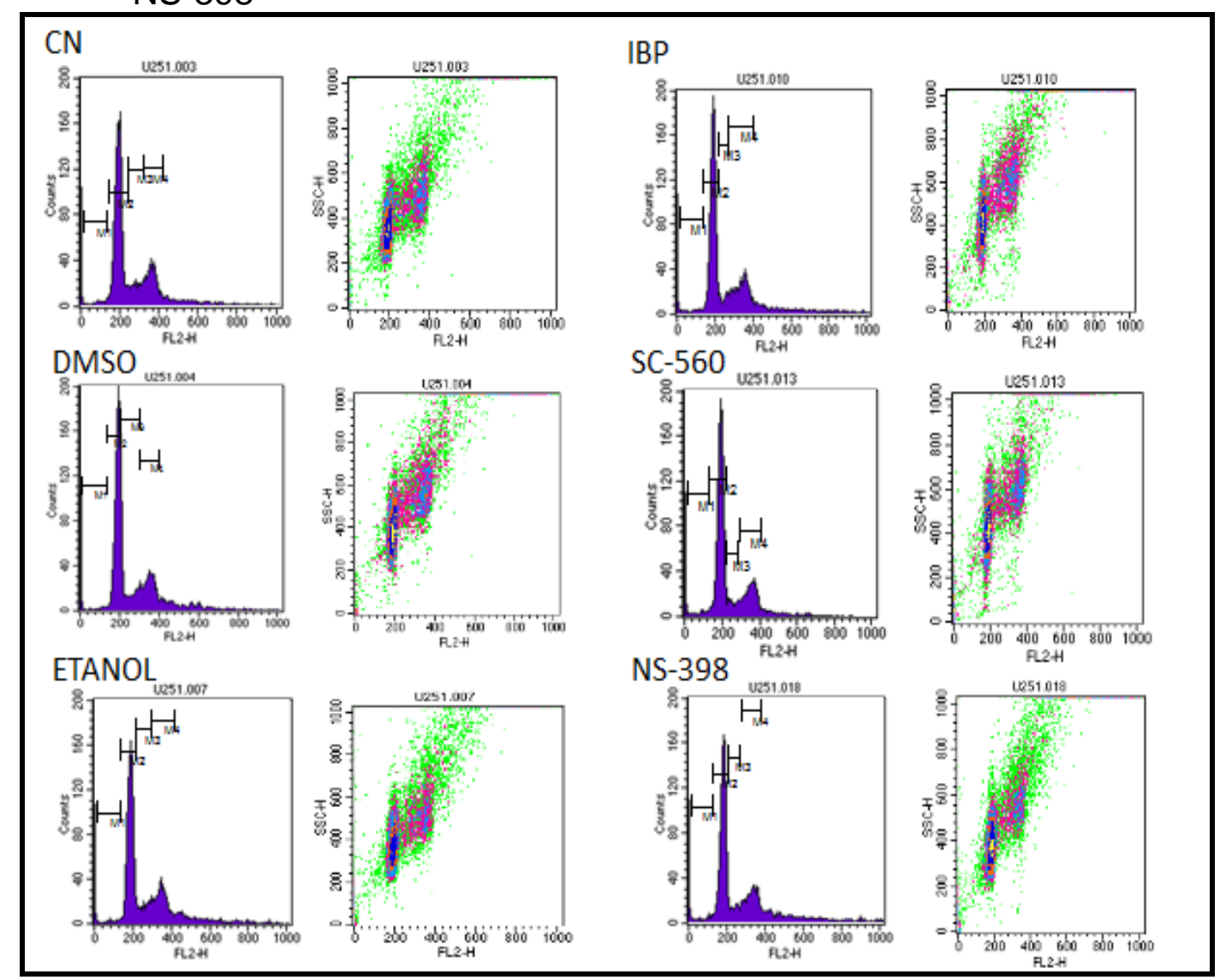

Tabela 3 - Porcentagem de células tratadas com IBP, SC-560 e NS-398 em cada fase do ciclo celular

\begin{tabular}{ccccc}
\hline $\begin{array}{c}\text { Fases do Ciclo } \\
\text { Celular }\end{array}$ & CN & IBP & SC-560 & NS-398 \\
\hline Sub G1 & $1,45 \%$ & $1,9 \%$ & $2,37 \%$ & $2,16 \%$ \\
& $( \pm 0,095)$ & $( \pm 0,33)$ & $( \pm 0,23)$ & $( \pm 0,25)$ \\
G1 & $50,49 \%$ & $50,21 \%$ & $49,71 \%$ & $47,77 \%$ \\
& $( \pm 1,05)$ & $( \pm 1,27)$ & $( \pm 3,02)$ & $( \pm 1,49)$ \\
S & $9,79 \%$ & $5,83 \%$ & $5,35 \%$ & $5,68 \%$ \\
& $( \pm 0,013)$ & $( \pm 1.07)$ & $( \pm 0,35)$ & $( \pm 0,89)$ \\
G2/M & $18,71 \%$ & $19,64 \%$ & $17,91 \%$ & $19,48 \%$ \\
& $( \pm 1,30)$ & $( \pm 2,07)$ & $( \pm 0,89)$ & $( \pm 1,52)$ \\
\hline
\end{tabular}


Figura 29 - Porcentagem de células em cada fase do ciclo celular

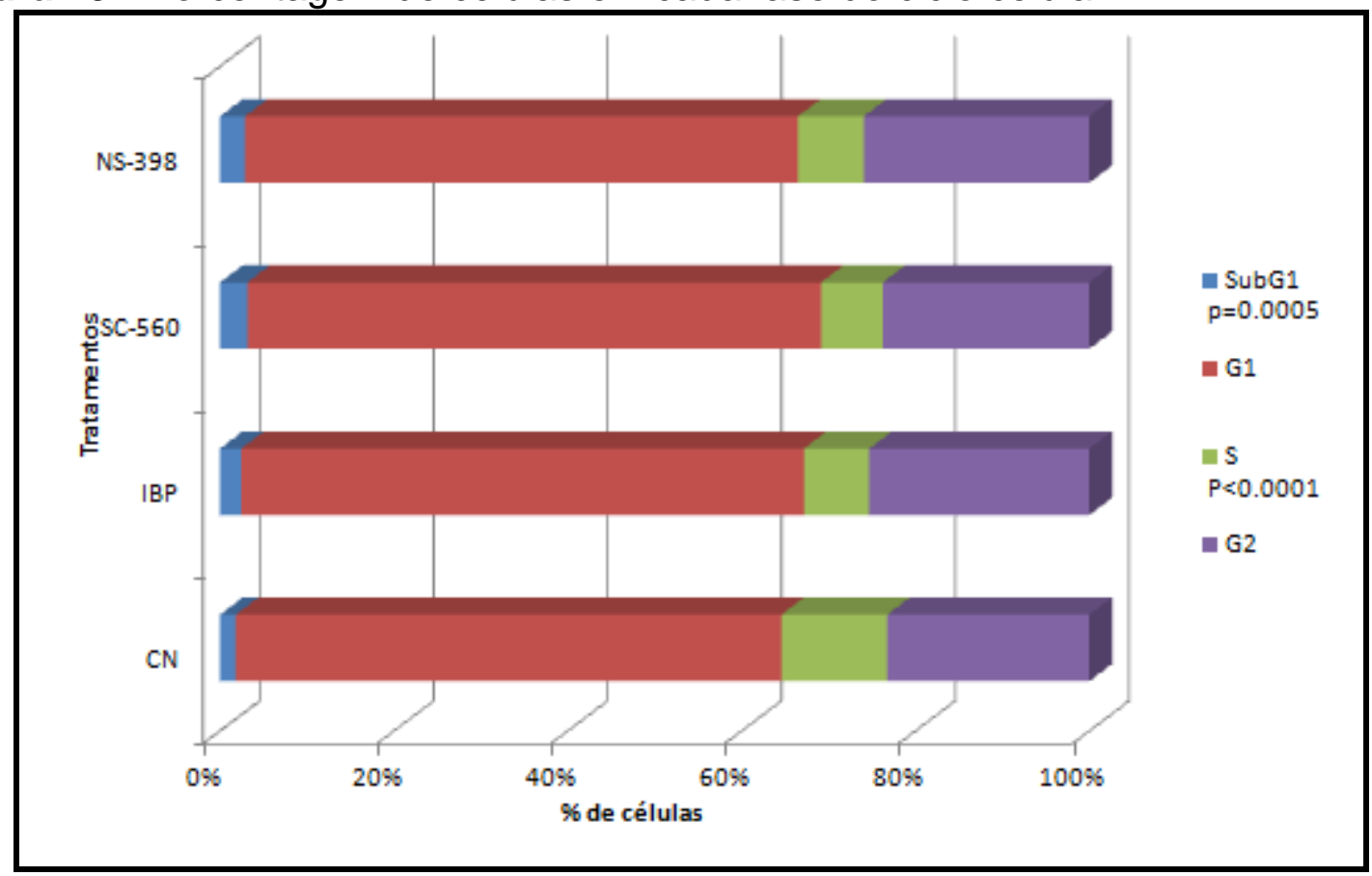

As análises de cada fase do ciclo celular para todos os tratamentos foram realizadas em relação ao controle normal $(\mathrm{CN})$.

\subsubsection{Análise do ciclo celular para os tratamentos com AH6809 e L161.982}

Os resultados das análises do ciclo celular do tratamento com os antagonista de EP2 e EP4, AH6809 e L161.982, respectivamente; encontram-se na Figura 30 e na Tabela 4. A análise do ciclo celular não apresentou diferença significativa em nenhuma fase do ciclo em relação ao controle, apesar de ter sido observado aumento de $20 \%$ na fase Sub-G1 do tratamento com AH6809. Também foi observado aumento na fase $\mathrm{G} 1$ de $30 \%$ e $52 \%$ e diminuição na fase $\mathrm{G} 2 / \mathrm{M}$ de $38 \%$ e $23 \%$, para os tratamentos com AH6809 e L161.982 respectivamente. Esses achados sugerem uma tendência de aumento de células em G1 e G2/M o que pode indicar parada do ciclo celular (Figura 31). 
Figura 30 - Gráficos de análise do ciclo celular das células tratadas com L161.982 e AH6809

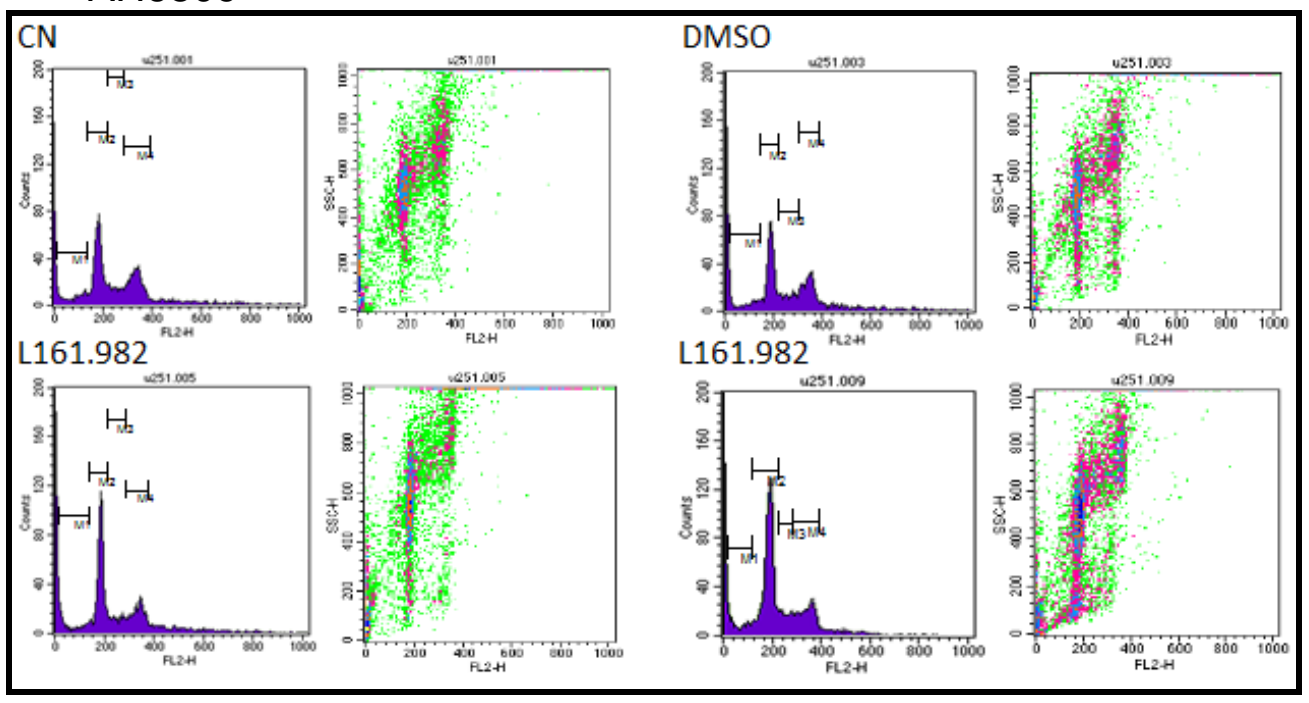

Tabela 4 - Porcentagem de células em cada fase do ciclo celular

\begin{tabular}{crrr}
\hline $\begin{array}{c}\text { Fases do Ciclo } \\
\text { Celular }\end{array}$ & CN & L161.982 & AH6809 \\
\hline Sub G1 & $5,72( \pm 0,56)$ & $5,36( \pm 0,66)$ & $6,82( \pm 0,36)$ \\
G1 & $20,70( \pm 1,44)$ & $31,43( \pm 4,77)$ & $27,06( \pm 1,62)$ \\
S & $7,23( \pm 0,58)$ & $6,70( \pm 1,23)$ & $6,79( \pm 0,70)$ \\
G2/M & $17,19( \pm 2,99)$ & $13,30( \pm 1,60)$ & $10,75( \pm 1,73)$ \\
\hline
\end{tabular}


Figura 31 - Porcentagem de células em cada fase do ciclo celular

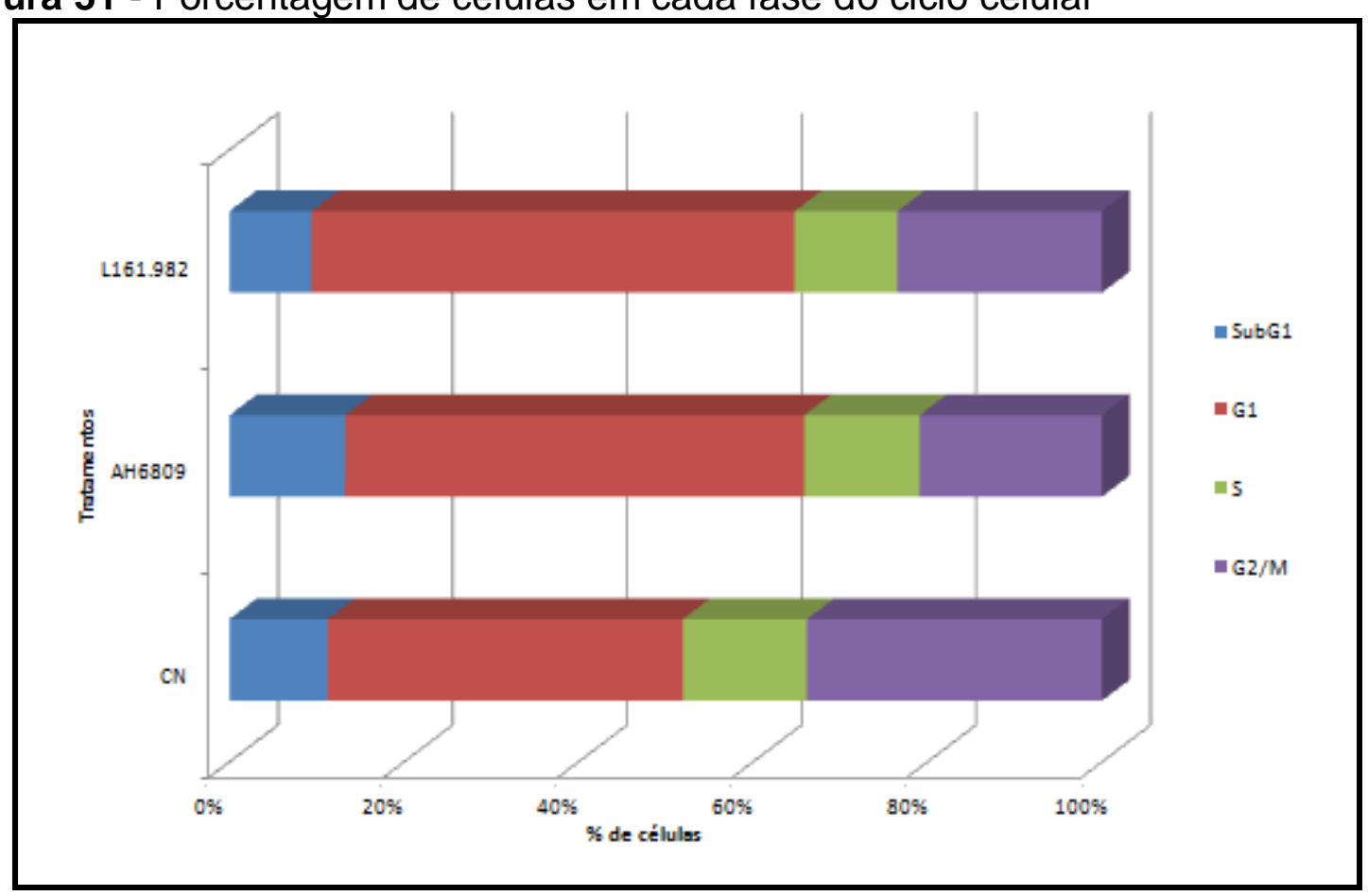

As análises de cada fase do ciclo celular para todos os tratamentos foram realizadas em relação ao controle normal $(\mathrm{CN})$. 


\section{DISCUSSÃo}

O glioblastoma multiforme é um dos tumores com piores prognósticos devido a sua alta mortalidade. A sobrevida média dos pacientes após o diagnóstico é de doze a quinze meses. Apesar dos avanços da neurocirurgia, da radio e da quimioterapia, não houve mudança na sobrevida desses pacientes. Portanto, novas terapias fazem-se necessárias (Wen, Kesari, 2008).

A migração celular é um evento crucial no desenvolvimento embrionário, na homeostase celular, na cicatrização de feridas, e em outros estados patológicos, como o processo de invasão celular e formação de metástase em câncer (Hurd et al., 2011). A agressividade dos gliomas está associada à rápida proliferação celular e alta capacidade de invasão de suas células, processo no qual a migração é crucial (Huse et al., 2013).

Estudos clínicos apontam que o uso de AINEs, inibidores não seletivos de COX-1 e COX-2, podem diminuir os riscos de tumores em gerais, incluindo os gliomas (Scheurer et al., 2008; Sivak-Sears et al., 2004). A isoforma induzida, COX-2, desempenha um papel na resposta inflamatória através da síntese de prostaglandinas, as quais são super expressas em gliomas (Buccoliero et al., 2006; Deininger, Schluesener, 1999). Em níveis elevados, as prostaglandinas, particularmente $\mathrm{PGE}_{2}$, estão associadas ao avanço do grau de malignidade do tumor e a pobre taxa de sobrevivência dos pacientes (Perdiki et al., 2007; Shono et al., 2001). Estudos in vitro mostram que o tratamento com acetaminofeno, um EINE; e com o inibidor específico de COX-2, NS-398; inibiram o crescimento de células tumorais, incluindo gliomas, através de mecanismos dependentes e independentes de COX-2 (Daugherty et al., 2011; Joki et al., 2000).

Wynne e Djakiem (2010) demonstraram que o tratamento com IBP foi capaz de inibir significativamente a migração celular em linhagens de câncer de próstata. Assim como, o tratamento com IBP também foi capaz de reduzir a migração celular em células de melanoma (Redpath et al., 2009). Em gliomas o uso do AINE indometacina, também inibiu o processo de migração nas linhagens celulares de glioma humano A172, U87MG, U251MG e U373MG (Wang et al., 2005).

Tais estudos dão suporte aos achados deste trabalho, cujos tratamentos na linhagem de glioblastoma multiforme U251-MG inibiram a migração celular em 48\% quando tratadas em transwell por 48 horas com IBP, inibidor não específico de COX; 
$42,5 \%$ quando tratadas com SC-560, inibidor específico de COX-1; e 24,8\% quando tratadas com NS-398, inibidor específico de COX-2. Contudo, quando tratadas por 48 horas, mas incubadas por apenas 12 horas em transwell, a inibição da migração foi maior, o tratamento com IBP inibiu 61\%; o tratamento com SC-560 inibiu $71 \%$ e o tratamento com NS-398 inibiu 59,5\%.

Esses dados corroboram com os estudos apresentados acima, e apontam que a inibição das enzimas COX-1 e COX-2, responsáveis pela síntese das prostaglandinas, inibem significativamente a migração celular na linhagem de glioma humano U251-MG. O estudo de migração em transwell por apenas 12 horas nos permitiu analisar que esse resultado de inibição é decorrente apenas do processo de inibição da migração celular, e não da inibição de outros processos como a proliferação, o que poderia estar envolvido quando o estudo foi realizado por um período maior, como por 48 horas.

Além disso, foi possível observar que o inibidor seletivo de COX-1, SC-560, foi o tratamento mais eficiente, inibindo cerca de $60 \%$ da migração celular quando somados os ensaios realizados, de 48 horas e de 12 horas. Isso se deve pelo fato da enzima COX-1 ser a isoforma constitutiva das células, assim sua inibição tem um efeito bastante expressivo. Através da análise da expressão gênica de COX-1 para este tratamento foi possível observar que houve uma diminuição significativa da expressão desta enzima, de 50,8\% $(p<0.001)$. Apesar de não ter sido observada diferença significativa na expressão proteica, sugere-se que essa redução da expressão gênica está associada ao efeito de maior inibição da migração celular apresentada por este tratamento.

Esses dados apontam que a inibição com o inibidor seletivo de COX-1 inibiu além da atividade desta enzima, inibindo a síntese da mesma, e com a sua síntese reduzida, sua atividade fica comprometida. Dessa maneira, a promoção da migração celular, um dos mecanismos onde COX está associada, também foi comprometida, por isso foi observado o efeito de maior inibição da migração celular.

Ishibashi et al. (2005) também observaram redução na migração celular nas células das linhagens celulares de glioma humano U87MG, A172, T98G, 138MG, U373MG, Hs683 e SW1088 quando tratadas com este mesmo inibidor seletivo de COX-1, o SC-560.

O segundo tratamento mais eficiente foi com IBP, inibidor não seletivo de COX-1 e COX-2, que inibiu 55\% da migração celular quando somados os ensaios de 
48 e de 12 horas. Este achado corrobora com os estudos prévios do nosso grupo, onde o IBP foi capaz de reduzir significativamente a migração celular da linhagem de glioma humano T98G (Gomes, 2011). Possivelmente isso se dá devido a inibição de ambas as isoformas pelo IBP, e dessa maneira foi observado um efeito expressivo com este tratamento.

Através da análise da expressão gênica de COX-1 para este tratamento foi observado aumento significativo de $130 \%$ da expressão do gene desta enzima. Contudo, na análise da expressão proteica observamos um ligeiro aumento não significativo de $17 \%$. Esses achados podem ter ocorrido como resposta à inibição desta enzima, um processo de reposição natural da célula, quando a ação da enzima foi inibida à célula iniciou uma maior síntese da mesma para suprir essa inibição; e possivelmente foi devido a este aumento da síntese de COX-1 que não pudemos observar um efeito ainda mais expressivo do que o observado para este tratamento.

Entretanto quando analisada a expressão gênica de COX-2 para o tratamento com IBP, não foi observada diferença significativa na expressão do gene desta enzima; ocorrendo o mesmo para a análise da expressão proteica. Entende-se que o efeito do IBP sobre COX-2, inibiu apenas a ação desta enzima, e não a síntese da mesma.

O tratamento com o inibidor específico de COX-2, NS-398, ao contrário do esperado, foi o tratamento que menos inibiu a migração celular, $42 \%$, somando os ensaios de migração. Pelo fato desta isoforma ser altamente expressa nesta linhagem celular, e em gliomas em geral, esperava-se que a sua inibição acarretasse uma redução mais expressiva da migração celular. Kuipers et al. (2007) demonstraram que a inibição de COX-2 com os inibidores seletivos celecoxib e NS398 culminaram em diminuição de $\mathrm{PGE}_{2}$; promoveram invasão menos eficiente $\mathrm{e}$ migração celular reduzida nas linhagens celulares de gliomas D384, U251MG e U87MG.

Ao analisar a expressão gênica de COX-2 para este tratamento, não foi observado diferença significativa em relação ao controle. Porém, em relação à análise de expressão proteica, foi observado aumento não significativo de $30,5 \%$ desta enzima.

Relaciona-se o aumento desta enzima à reduzida inibição da migração celular neste tratamento comparado aos demais. O inibidor seletivo NS-398 inibiu a 
atividade de COX-2 promovendo aumento dos níveis desta enzima na célula, como resposta ao mecanismo compensatório da enzima. Possivelmente, este aumento de COX-2 não permitiu sua maior ação inibitória na migração celular.

As prostaglandinas, incluindo $\mathrm{PGE}_{2}$, estão envolvidas em mecanismos de promoção da proliferação celular, o que em gliomas é um dos principais mecanismos que culminam na agressividade deste tumor, como citado anteriormente. Nossos estudos apontam que o tratamento com IBP, SC-560 e NS398 inibiu significativamente a proliferação celular em 60\%, 55\% e 58\%, respectivamente. Além disso, estes tratamentos foram capazes de aumentar a morte celular em $31 \%, 64 \%$ e $49 \%$, respectivamente. Estes achados corroboram com estudos da literatura onde demonstraram que COX-1 e COX-2 estão super expressas em diversos tumores, acarretando uma maior síntese de prostanóides e assim aumento da proliferação celular e de resistência à apoptose (Gupta et al., 2003; Méric et al., 2006). Sendo assim, a super expressão de COX-2 em tumores está diretamente relacionada ao aumento de $\mathrm{PGE}_{2}$ (Wang et al., 2007).

A elevada expressão de COX-2 resulta em uma elevada produção de $\mathrm{PGE}_{2}$, promovendo o crescimento do tumor através dos receptores acoplados à proteína $\mathrm{G}$, denominados EP1, EP2, EP3 e EP4. A via de sinalização destes receptores controlam a proliferação celular, invasão, apoptose e angiogênese (Kambe et al., 2008). Pioneiramente, demonstramos em nosso estudo que a linhagem celular de glioma humano U251-MG expressa todos os receptores de PGE 2 : EP1, EP2, EP3 e EP4.

A expressão gênica de EP2 apresentou aumento significativo de 123\% para o tratamento com o antagonista deste receptor, AH6809, em relação ao controle. Porém os demais tratamentos não apresentaram diferença significativa na análise da expressão gênica. Em relação à análise de expressão proteica não foi observada diferença significativa entre o tratamento com AH6809 em relação ao controle. Já os demais tratamentos, IBP (inibidor não específico de COX-1 e COX-2), SC-560 (inibidor específico de COX-1) e NS-398 (inibidor específico de COX-2) não apresentaram expressão proteica para este receptor.

Sugere-se que a elevada expressão gênica observada no tratamento com o antagonista de EP2, AH6809, pode ser resultante do mecanismo de compensação celular, pois como o receptor EP2 foi inibido pelo seu antagonista, a célula aumentou a síntese deste receptor a fim de manter a homeostase celular. Talvez devido a este 
mecanismo compensatório a inibição de EP2 não teve o efeito esperado, como a inibição significativa da proliferação celular.

Não obstante, a expressão gênica de EP4 apresentou aumento significativo de $85,5 \%$ para o tratamento com IBP (inibidor não seletivo de COX-1 e COX-2). Entretanto, não foi observada diferença significativa na expressão deste gene para os demais tratamentos em relação ao controle. $\mathrm{Na}$ análise de expressão proteica foi observado aumento significativo de $100 \%$ para o tratamento com antagonista deste receptor, L161.982. Não houve diferença significativa na expressão proteica dos tratamentos com IBP e SC-560, apesar do último apresentar aumento não significativo de 60\%. Porém o tratamento com NS-398 (inibidor específico de COX-2) não apresentou expressão proteica para este receptor.

O aumento da expressão gênica de EP4 no tratamento com IBP e a tendência de aumento da expressão proteica observada no tratamento com SC-560, sugerem que este receptor pode estar associado na modulação não apenas de COX-2 como apontado por Kambe et al. (2008). Mas também na modulação de COX-1, pelo fato do IBP ser um inibidor não específico de COX, inibindo ambas as isoformas; e pelo SC-560 inibir apenas COX-1. Estes achados apontam que em resposta à inibição destas enzimas, a célula realizou um mecanismo compensatório, com aumento de síntese do receptor EP4, para assim aumentar a produção de $\mathrm{PGE}_{2}$, e manter a homeostase celular.

A expressão de EP2 e EP4 é encontrada altamente regulada em tecidos tumorais, como em câncer de colo retal e de mama (Chang et al., 2004; Sonoshita et al., 2001). Estudos apontaram que EP4 está super regulado em astrocitomas e em GBM (Fiebich et al., 2001; Raza et al., 2004). E que a elevada concentração de COX-2, através da ativação de EP2 e EP4, é um potencial modulador da progressão do GBM. Estes estudos corroboram com nossos achados, onde a expressão proteica de EP2 não foi observada para nenhum dos tratamentos com os inibidores de COX. Não obstante, não foi observada expressão proteica de EP2 e EP4 para o tratamento com o inibidor específico de COX-2, NS-398.

Portanto EP2 e EP4 estão associados na modulação de COX-1 e COX-2 na linhagem de glioma humano U251-MG. Além disso, também se conclui que a inibição de COX-1 e COX-2 inibem a migração celular, a proliferação e aumentam a morte celular na linhagem U251-MG (Figura 32). 
Figura 32 - llustração demonstrando os principais resultados deste estudo

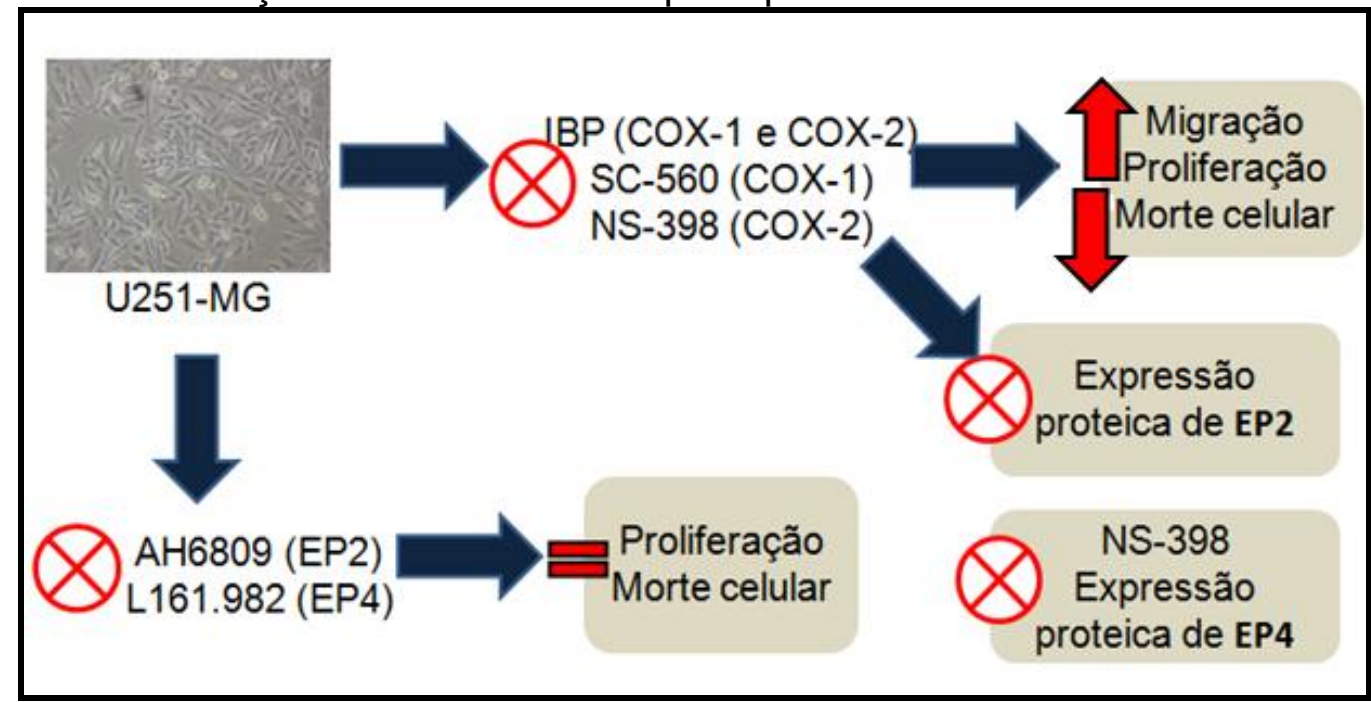

Estes achados in vitro são muito positivos para futuras perspectivas de terapias deste tumor tão agressivo. O IBP é um anti-inflamatório de fácil acesso e de baixo custo em relação às terapias convencionais existentes para este tumor. Porém, o tumor é multigênico, com diversos genes bloqueados, mutados ou super expressos, o que dificulta a eficácia do tratamento. Sendo assim, acredita-se que os experimentos realizados neste trabalho devem ser expandidos para outras linhagens celulares com diferentes genótipos a fim de verificar se a ação inibitória da migração e proliferação celular com este tratamento (IBP) também é eficaz. Contudo, sugerese em outra etapa do trabalho, realizar estes testes in vivo, para dessa maneira conseguir analisar sistemicamente os efeitos desse tratamento. 


\section{CONCLUSÃO}

O presente estudo demonstrou que a inibição de COX-1 e COX-2 através do anti-inflamatório não esteroidal IBP, e dos inibidores seletivos SC-560 e NS-398, respectivamente; inibiram a migração, a proliferação e aumentaram a morte celular na linhagem U251-MG. Além disso, todos os tratamentos inibiram a expressão proteica do receptor de $\mathrm{PGE}_{2}$, EP2. Não obstante, o tratamento com o inibidor seletivo de COX-2, NS-398 inibiu a expressão do receptor EP4. Portanto, concluímos que COX-1 e principalmente COX-2 estão associadas à $\mathrm{PGE}_{2}$, a qual está envolvida na migração, proliferação e morte celular na linhagem U251-MG.

Estes achados são muito positivos em relação às futuras terapias, já que 0 IBP é um anti-inflamatório de fácil acesso e de baixo custo. Além disso, este estudo demonstrou o potencial de COX, o que abre novas opções de tratamentos para este tumor tendo como alvo mecanismos de inibição de $\mathrm{COX}$ e de $\mathrm{PGE}_{2}$. 


\section{REFERÊNCIAS*}

Altinoz MA, Ozar E, Taskin M, Bozcali E, Bilir A, Altug T, Aydiner A, Sav A, Vascularization pattern of $\mathrm{C} 6$ glioma is modified with medroxyprogesterone acetate and ibuprofen in Wistar rat brain. Pathol Oncol Res. 2001;7:185-9.

Amano H. Hayashi I, Endo H, Kitasato H, Yamashina S, Maruyama T, Kobayashi M, Satoh K, Narita M, Sugimoto Y, Murata T, Yoshimura H, Narumiya S, Majima M. Host prostaglandina E (2)- EP3 signaling regulates tumor-associated angiogenesis and tumor growth. J Exp Med. 2003;197(2):221-32.

Andrew JD, Jakiew D, Krygier S, Andrews P. Superior effectiveness of ibuprofen compared with others for reducing the survival of human prostate cancer cells. Chemother Pharmacol. 2002;50(4):277-84.

Badawi AF, El Sohemy A, Stephen LL, Ghoshal AK, Archer MC. Modulation of the expression of the cyclooxygenase 1 and 2 genes in rat mammary glands: role of hormonal status and dietary fat. Adv Exp Med Biol. 1999;469:119-24.

Baron JA, Sandle RS. Nonsteroidal anti-inflammatory drugs and cancer prevention. Annu Rev Med. 2000;51:511-23.

Barzon L, Zanusso M, Colombo F, Palu G. Clinical trials of gene therapy, virotherapy, and immunotherapy for malignant gliomas. Cancer Gene Ther. 2006;13:539-54.

Benadiba M. Análise da Expressão de Proteínas Envolvidas no Controle do Ciclo Celular, Apoptose, Angiogênese, Invasão e Migração das Células C6, In Vitro e In Vivo, Após o Tratamento Com o Ácido Gama Linolênico (GLA) E Com Um Novo Complexo Dirutênico Contendo Ibuprofeno (Ru-lbp). [tese (Doutorado em Ciências, Biologia Celular e Tecidual)]. São Paulo: Instituto de Ciências Biomédicas, Universidade de São Paulo; 2008.

Buccoliero AM, Caldarella A, Gheri CF, Taddei A, Paglierani M, Pepi M, et al. Inducible cyclooxygenase (COX-2) in glioblastoma-clinical and immunohistochemical (COX-2-VEGF) correlations. Clin Neuropathol. 2006;25:59-66.

Buonerba C, Di Lorenzo G, Marinelli A, Federico P, Palmieri G, Pio CM, Peluso G, De Plácido $\mathrm{S}$, Sampsone $\mathrm{JH}$. A comprehensive outlook on intracerebral therapy of malignant gliomas. Oncology Hematology. 2010;80(1):54-68.

Carneiro SLA, Távora FRF, Souza MHLP, Ribeiro RA. Ciclooxigenase e Câncer Uma Breve Revisão. Pesquisa Médica. 2004;2(7):39-45.

*De acordo com: International Committee of Medical Journal Editors. [Internet]. Uniform requirements for manuscripts submitted to Biomedical Journal: sample references. [updated 2011 Jul 15]. Available from: http//www.icmje.org. 
Clarke J, Butowski N, Chang S. Recent Advances in Therapy for Glioblastoma. Arch Neurol. 2010;67(3):279-83.

Chang SH, Liu CH, Conway R, Han DK, Nithipatikom K, Trifan OC, Lane TF, Hla F. Role of prostaglandin E2-dependent angiogenic switch in cyclooxygenase 2-induced breast cancer progression. Proc Natl Acad Sci U S A. 2004;101:591-6.

Chen YC, Shen SC, Lee WR, Hou WC, Yang LL, Lee TJ. Inhibition of nitric oxide synthase inhibitors and lipopolysaccharide induced inducible NOS and cyclooxygenase-2 gene expressions by rutin, quercetin, and quercetin pentaacetate in RAW 264.7 macrophages. J Cell Biochem. 2001;82:537-48.

Chiu WT, Shen SC, Chow JM, Lin CW, Shia LT, Chen YT. Contribution of reactive oxygen species to migration/invasion of human glioblastoma cells U87 via ERKdependent COX-2/PGE2 activation. Neurobiology Dis. 2010;37:118-29.

Coleman RA, Smith WL, Narumiya S. International Union of Pharmacology Classification of Prostanoid Receptors: properties, distribution, and Structure of the receptors and their subtypes. Pharmacol Rev. 1994;46(2):205-29.

Colquhoun A. Lipids, Mitochondria and Cell Death: Implications in Neuro-oncology. Mol Neurobiology. 2010;42:76-88.

Das P, Puri T, Jha P, Pathak P, Joshi N, Suri V, Sharma MC, Sharma BS, Mahapatra AK, Suri A, Sarkar C. A clinicopathological and molecular analysis of glioblastoma multiforme with long-term survival. Neuroscience Clin J. 2011;18(1):66-70.

Daugherty SE, Moore SC, Pfeiffer RM et al. Nonsteroidal Anti-inflammatory Drugs and Glioma in the NIH-AARP Diet and Health Study Cohort. Cancer Prev Res. $2011 ; 4: 2027-34$.

Deininger MH, Schluesener HJ. Cyclooxygenases-1 and -2 are differentially localized to microglia and endothelium in rat EAE and glioma. J Neuroimmunol. 1999;95:2028.

Dorsm RT, Gutkind JS. G-protein-coupled receptors and cancer. Nat Ver Cancer. 2007;(2):79-94.

Instituto Nacional de Câncer. Estimativa 2010: incidência de câncer no Brasil / Instituto Nacional de Câncer. Rio de Janeiro: INCA; 2009.

Farrel CL, Megyesi J, Del Maestro RF. Effect of ibuprofen on tumor growth in the C6 spheroid implantation glioma model. J Neurosurg. 1988;68:925-30.

Fiebich BL, Schleicher S, Spleiss O, Czygan M, Hull M, Mechanisms of prostaglandin E2-induced interleukin-6 release in astrocytes: possible involvement of EP4-like receptors, p38 mitogen-activated protein kinase and protein kinase. J Neurochem. 2001;79:950-8. 
Fujino $\mathrm{H}$, Chen XB, Regan JW, Murayama T. Indomethacin decreases Ep2 prostanoid receptor expression in colon cancer cells. Biochem Biophys Res Commun. 2007;359(3):568-73.

Gallo O, Masini E, Bianchi B, Bruschini S, Paglierani M, Franchi A. Prognostic significance of cyclooxygenase-2 pathway and angiogenesis in head and neck squamous cell carcinoma. Hum Pathol. 2002;33(7):708-14.

Gomes NR. Análise do papel da prostaglandina E2 na proliferação, migração e apoptose na linhagem de glioma humano T98Ge o efeito do Ácido Gama Linolênico e lbuprofeno sobre este prostanóide. [dissertação (Mestrado em Biologia Celular e Tecidual)]. São Paulo: Instituto de Ciências Biomédicas, Universidade de São Paulo; 2011.

Greenhough A, Smartt HJ, Moore AE, Robertes HR, Williams AC, Paraskeva C. The COX-2/PGE2 pathway: key roles in the hallmarks of cancer and adaptation to the tumour microenvironment. Carcinogenesis. 2009;30(3):377-86.

Gupta RA, Tejada LV, Tong BJ, Das SK, Morrow JD, Dey SK, et al. Cyclooxygenase1 is overexpressed and promotes angiogenic growth factor production in ovarian cancer. Cancer Res. 2003;63:906-11.

Ishibashi M, Bottone JGF, Taniura S, Kamitani H, Waranable T, Eling ET. The cyclooxygenase inhibitor indomethacin modulates gene expression and represses the extracellular matrix protein laminin $\mathrm{y} 1$ in human glioblastoma cells. 2005;302(2):244-52.

Johnson CC, Hayes RB, Schoen RE, Gunter MJ, Huang WY. Non-Steroidal antiinflammatory drugs use and colorectal polyps in the prostate, lung, colorectal, and ovarian cancer screening trial. AMJ Gastroenterol. 2010;105(12):2646-55.

Joki T, Heese O, Nikas DC, Bello L, Zhang J, Kraeft SK, et al. Expression of cyclooxygenase 2 (COX-2) in human glioma and in vitro inhibition by a specific COX2 inhibitor, NS-398. Cancer Res. 2000;60:4926-31.

Hata AN, Breyer RM. Pharmacology and signaling of prostaglandin receptors: multiple roles in inflammation and immune modulation. Pharmacol Ther. 2004;103(2):147-66.

Helseth R, Helseth E, Johannesen TB, Langberg CW, Lote K, Ronning P, Scheie D, Vik A, Meling TR. Overall survival, prognostic factors, and repeated surgery in a consecutive series of 516 patients with glioblastoma multiforme. Acta Neurol Scand. 2010;122:159-67.

Hinz B, Brune K. Ciclooxygenase-2 - 10 years later. J Pharmacol Exp Ther. 2002;300(2):367-75.

Hurd TR, Degennaro M, Lehmann R. Redox regulation of cell migration and adhesion. Trends Cell Biol. 2011;22:107-15. 
Huse JT, Holland E, DeAngelis ML. Glioblastoma: Molecular Analysis and Clinical Implications. Annu Rev Med. 2013;64:17.1-12.

Kambe A, Iguchi G, Moon Y, Kamitani H, Watanabe T, Eling TE. Regulation of EP4 expression via the Sp-1 transcription factor: Inhibition of expression by anti-cancer agents. Biochimica et Biophysica Acta. 2008;1211-19.

Kamei D, Murakami M, Nakatani Y, Ishikawa Y, Ishii T, Kudo I. Potential role of microsomal prostaglandin E synthase-1 in tumorigenesis. J Bio Chem. 2009; 278(21):19396-405.

Kleihues P, Burger PC, Scheithauer BW. The new WHO classification of brain tumours. Brain Pathol. 1993;3(3):255-68.

Kuipers GK, Slotman BJ, Wedekind LE, Stoter TR, Van Den Berg J, Sminia P, Lafleur MVM. Radiosensitization of human glioma cells by cyclooxygenase-2 (COX2) inhibition: Independent on COX-2 expression and dependent on the COX-2 inhibitor and sequence of administration. Int J Radiat Biol. 2007;83(10):677-85.

Kummer CL e Coelho TC, Antiinflamatórios Não Esteróides Inibidores da Ciclooxigenase-2 (COX-2): Aspectos Atuais. 2002;52:4:498-512.

Kundo I, Murakami M. Prostaglandin and synthase, a terminal enzyme for prostaglandin E2 biosynthesis. J. Biochem Mol Biol. 2008;38(6):633-8.

Larkins TL, Nowell M, Singh S, Sanford GL. Inhibiton of ciclooxygenase-2 decreases breast cancer cell motility, invasion and matrix metalloproteinase expression. BMC Cancer. 2006;10(6):181.

Lim JW, Kim H, Kim KH. Nuclear factor-kappaB regulates cyclooxigenase-2 expression and cell proliferation in human gastric cancer cells. Lab Invest. 2001;81: 349-60.

Lima RSF, Kahn AS, Soletti RC, Biasoli D, Alves T, Fonseca ACC, Garcia C, Romão L, Brito J, Holanda-Afonso R, Faria J, Borges H, Moura-Neto V. Glioblastoma: Therapeutic challenges, what lies ahead. Biochimica et Biophysica Acta. 2012;1826:338-49.

Louis DN, Ohgaki H, Wiestler DO, Cavanee KW, Burger CP, Jouvet A, Scheithauer BW, Kleihues P. The 2007 WHO Classification of Tumours of the Central Nervous System. Acta Neuropathol. 2007;114:97-109.

Mahmud SM, Franco EL, Turner D, Platt RW, Beck P, Skarsgard D, Tonita J, Sharpe C, Aprikian AG. Use of non-steroidal anti-inflammatory drugs ans prostate cancer risk: a population-based nested case-control study. PLoS One. 2010;6(1):16412.

Marshall JC, Fernandes BF, Di Cesare S, Maloney SC, Logan PT, Antecka E, Burnier MN. The use of a cyclooxygenase-2 inhibitor (Nepafenac) in an ocular and metastatic animal model of uveal melanoma. Carcinogenesis. 2007;28:2053-8. 
Méric JB, Rottey S, Olaussen K, Soria JC, Khayat D. Cyclooxygenase-2 as a target for anticancer drug development critical reviews in oncology. Hematology. 2006;59:51-64.

Miao L, Grebhardt S, Shi J, Peipe I, Zhang J, Mayer D. Prostaglandin E2 stimulates S100A8 expression by activating protein kinase A and CCAAT/enhancer-bindingprotein-beta in prostate cancer cells. Int J Biochem Cell Biol. 2012;44:1919-28.

Miyake JA. Estudo Morfológico e Molecular de Proteínas Envolvidas no Processo de Invasão, Migração e Angiogênese em Gliomas Tratados Com Ácido GamaLinolênico. [tese (Doutorado em Biologia Celular e Tecidual). São Paulo: Instituto de Ciências Biomédicas, Universidade de São Paulo; 2009.

Müller-Decker K, Fürstenberger G. The cyclooxygenase-2-mediated prostaglandin signaling is causally related to epithelial carcinogenesis. Mol Carcinog. 2007;46:70510.

Nathoo N, Barnett GH, Golubic M, The eicosanoids cascade: possible role in gliomas and meningiomas. J Clin Pathol. 2004;57(1):6-13.

Newa M, Bhandari KH, Kim JO, Im JS, Kim JA, Yoo BK, Woo JS, Choi HG, Yong CS. Enhancement of solubility, dissolution and bioavailability of ibuprofen in solid dispersion systems. Chem Pharm Bull. 2008;56(4):568-74.

Ohgaki H, Kleihues P. Genetic Pathways to Primary and Secondary Glioblastoma. The Amer Jour of Pathol. 2007;1445-53.

Perdiki M, Korkolopoulou P, Thymara I, Agrogiannis G, Piperi C, Boviatsis E, et al. Cyclooxygenase-2 expression in astrocytomas. Relationship with microvascular parameters, angiogenic factors expression and survival. Mol Cell Biochem. 2007;295:75-83.

Raza SM, Fuller GN, Rhee CH, Huang S, Hess K, Zhang W, Sawaya R. Identification of necrosis-associated genes in glioblastoma by cDNA microarray analysis. Clin Cancer Res. 2004;10:212-21.

Redpath M, Marques CM, Dibden C, Waddon A, Lalla R, Macneil S. Ibuprofen and hydrogel-released ibuprofen in the reduction of inflammation-indiced migration in melanoma cells. Br J Dermatol. 2009;161(1):25-33.

Ricci-Vitiani L, Pallini R, Biffoni M, Todaro M, Invernici G, Cenci T, Maira G, Parati EA, Stassi G, Larocca LM, De Maria R. Tumour vascularization via endothelial differentiation of glioblastoma stem-like cells. Nature. 2010;468:824-8.

Rich JN, Bigner DD. Development of Novel Targeted Therapies in the Treatment of Malignant Glioma. Nature. 2004;3:430-46.

Sarah E. Daugherty, Steven C. Moore, Ruth M. Pfeiffer, et al. Nonsteroidal Antiinflammatory Drugs and Glioma in the NIH-AARP Diet and Health Study Cohort. Cancer Prev Res. 2011;4:2027-34. 
Scheurer ME, El-Zein R, Thompson PA, Aldape KD, Levin VA, Gilbert MR, et al. Long-term anti-inflammatory and antihistamine medication use and adult glioma risk. Cancer Epidemiol Biomarkers Prev. 2008;17:1277-81.

Shono T, Tofilon PJ, Bruner JM, Owolabi O, Lang FF. Cyclooxygenase-2 expression in human gliomas: prognostic significance and molecular correlations. Cancer Res. $2001 ; 61: 4375-81$.

Sivak-Sears NR, Schwartzbaum JA, Miike R, Moghadassi M, Wrensch M. Casecontrol study of use of nonsteroidal antiinflammatory drugs and glioblastoma multiforme. Am J Epidemiol. 2004;159:1131-9.

Smyth EM, Grosser T, Wang M, Yu Y, FitzGerald GA. Prostanoids in health and disease. J Lipid Res. 2009;50:423-8.

Sonoshita M, Takaku K, Sasaki N, Sugimoto Y, Ushikubi F, Narumiya S, Oshima M, Taketo MM. Acceleration of intestinal polyposis through prostaglandin receptor EP2 in Apc(Delta 716) knockout mice. Nat Med. 2001;7:1048-51.

Sugimoto Y, Narumiya S: Prostaglandin E receptor. J Biol Chem. $2007 ; 282(16): 1613-7$.

Sung YM, He G, Fischer SM. Lack of expression of the EP2 but not EP3 receptor for prostaglandin E2 results in suppression of skin tumor development. Cancer Res. 2005;65(20):9304-11.

Telliez A, Furman C, Pommery N, Henichart JP. Mechanisms leading to COX-2 expression and COX-2 induced tumorigeneses: topical therapeutic strategies targeting COX-2 expression and activity. Anticancer Agents Med Chem. 2006;6(3):187-208.

Ulrich CM, Bigler J, Potter JD. Non-steroidal anti-inflammatory drugs for cancer prevention: promise, perils and pharmacogenetics. Nat Rev Cancer. 2006;6(2):13040.

Vara JAK, Casado E, Castro J, Cejas P, Belda-Iniesta C, González-Barín M. PI3K/Akt signalling pathway and cancer. Cancer Treat Ver. 2004;30:193-204.

Wakimoto, N, Wolf I, Yin D, O'Kelly J, Akagi T, Abramovitz L, Black KL, Tai HH, Koeffler HP. Nonsteroidal anti-inflammatory drugs suppress glioma via 15hydroxyprostaglandin dehydrogenase. Cancer Res. 2008;68:6978-86.

Wang M, Yoshida D, Liu S, Teramoto A. Inhibition of cell invasion by indomethacin in gliomas cell lines: in vitro study. J Neurooncol. 2005;72(1):1-9.

Wang D, DuBois R. Eicosanoids and cancer. Nat Rev Cancer. 2010;10(3):181-93.

Wang D, DuBois R. The Role of Anti-inflammatory Drugs in Colorectal Cancer. Annu. Rev Med. 2012;17. 
Wang MT, Honn KV, Nie D. Ciclooxygenases, prostanoids, and tumor progression. Cancer Metastasis Rev. 2007;26(3-4):525-34.

Wen PY, Kesari S. Malignant gliomas in adults. N Engl J Med. 2008;359:492-507.

Wynne S, Djakiew D. NSAID Inhibition of Prostate Cancer Cell Migration Is Mediated by Nag-1 Induction via the p38 MAPK-p75NTR Pathway p38 MAPK-p75NTR Pathway. Molecular Cancer Research. 2010;8:1656-64.

Xu K, Chang CM, Gao H, Shu HK. Epidermal growth factor-dependent cyclooxygenase-2 induction in gliomas requires protein kinase C-delta. Oncogene. 2009;28:1410-20. 